UNIVERSIDADE DE BRASÍLIA

FACULDADE DE TECNOLOGIA

DEPARTAMENTO DE ENGENHARIA CIVIL E AMBIENTAL

\title{
APLICAÇÃO DO SISTEMA COMBINADO POR FILTRO ANAERÓBIO SEGUIDO DE BIOFILTRO AERADO SUBMERSO AO TRATAMENTO DE ESGOTOS SANITÁRIOS DE UNIDADES RESIDENCIAIS UNIFAMILIARES
}

THALLYTA MANUELA ROSÁRIO DA SILVA

ORIENTADOR: MARCO ANTONIO ALMEIDA DE SOUZA CO-ORIENTADORA: YOVANKA PÉREZ GINORIS

\begin{abstract}
DISSERTAÇÃO DE MESTRADO EM TECNOLOGIA AMBIENTAL E RECURSOS HÍDRICOS
\end{abstract}

PUBLICAÇÃO: PTARH.DM - 187/16

BRASÍLIA/DF: AGOSTO - 2016 
UNIVERSIDADE DE BRASÍLIA

FACULDADE DE TECNOLOGIA

DEPARTAMENTO DE ENGENHARIA CIVIL E AMBIENTAL

APLICAÇÃO DO SISTEMA COMBINADO POR FILTRO ANAERÓBIO SEGUIDO DE BIOFILTRO AERADO SUBMERSO AO TRATAMENTO

DE ESGOTOS SANITÁRIOS DE UNIDADES RESIDENCIAIS

UNIFAMILIARES

THALLYTA MANUELA ROSÁRIO DA SILVA

DISSERTAÇÃO SUBMETIDA AO DEPARTAMENTO DE ENGENHARIA CIVIL E AMBIENTAL DA FACULDADE DE TECNOLOGIA DA UNIVERSIDADE DE BRASÍLIA COMO PARTE DOS REQUISITOS NECESSÁRIOS PARA A OBTENÇÃO DO GRAU DE MESTRE EM TECNOLOGIA AMBIENTAL E RECURSOS HÍDRICOS.

\section{APROVADA POR:}

Prof. Marco Antonio Almeida de Souza, Ph.D. (ENC-UnB) (Orientador)

Prof. a Yovanka Pérez Ginoris, Dr (ENC-UnB) (Co-orientadora)

Prof. $^{a}$ Ariuska Karla Barbosa Amorim, Dr (ENC-UnB) (Examinador Interno)

Prof. Douglas José da Silva, Dr (UCB) (Examinador Externo)

BRASÍLIA/DF, 15 DE AGOSTO DE 2016. 


\section{FICHA CATALOGRÁFICA}

ROSÁRIO, THALLYTA MANUELA DA SILVA.

Aplicação do sistema combinado por filtro anaeróbio seguido de biofiltro aerado submerso ao tratamento de esgotos sanitários de unidades residenciais unifamiliares.

xix, 112p. 210 x 297 mm (ENC/FT/UnB, Mestre, Tecnologia Ambiental e Recursos Hídricos, 2016).

Dissertação de Mestrado - Universidade de Brasília. Faculdade de Tecnologia. Departamento de Engenharia Civil e Ambiental.

1. Sistema combinado para tratamento de esgotos 3. Filtro Anaeróbio

2. Redução da produção de lodo.

4. Biofiltro Aeróbio Submerso

I. ENC/FT/UnB

II. Título (série)

\section{REFERÊNCIA BIBLIOGRÁFICA}

ROSÁRIO, T.M.S. (2016). Aplicação do sistema combinado por filtro anaeróbio seguido de biofiltro aerado submerso ao tratamento de esgotos sanitários de unidades residenciais unifamiliares. Dissertação de Mestrado em Tecnologia Ambiental e Recursos Hídricos, Publicação PTARH.DM-187/2016, Departamento de Engenharia Civil e Ambiental, Universidade de Brasília, Brasília, DF, 112p.

\section{CESSÃO DE DIREITOS}

AUTOR: Thallyta Manuela Rosário da Silva.

TÍTULO: Aplicação do sistema combinado por filtro anaeróbio seguido de biofiltro aerado submerso ao tratamento de esgotos sanitários de unidades residenciais unifamiliares.

GRAU: Mestre

ANO: 2016

É concedida à Universidade de Brasília permissão para reproduzir cópias desta dissertação de mestrado e para emprestar ou vender tais cópias somente para propósitos acadêmicos e científicos. O autor reserva outros direitos de publicação e nenhuma parte dessa dissertação de mestrado pode ser reproduzida sem autorização por escrito do autor.

Thallyta Manuela Rosário da Silva tmanuela1@gmail.com 
Dedico a toda minha família, em especial aos meus pais, Alvaro e Marcelina Fleury, fonte de fé, de incentivo e de apoio a todas as minhas decisões. 


\section{AGRADECIMENTOS}

Agradeço primeiramente a Deus, por me conceder o dom da vida, por me dar forças diante aos desafios, por se mostrar sempre presente em minha caminhada por meio dos anjos que colocou em minha vida.

Agradeço ao meu orientador Prof. Marco Antonio Almeida de Sousa e minha coorientadora Prof. ${ }^{\text {a }}$ Yovanka Pérez Ginoris, por compartilharem suas experiências e conhecimentos, além da paciência, compreensão, incentivos, apoio constante e grande amizade. Muito obrigada!

A todos os professores do Programa de Tecnologias Ambientais e Recursos Hídricos da UnB, Marco Antônio, Yovanka Pérez, Sérgio Koide, Cristina Brandão, Conceição Alves, Dirceu Reis, Lenora Gomes, Ariuska Amorim, Ricardo Minoti, Oscar Cordeiro Netto e Wagner de Almeida pela transmissão de conhecimentos e colaborar para nosso crescimento profissional.

Aos meus amados pais Alvaro e Marcela, pelo amor incondicional, por me apoiarem em todas as minhas decisões, por sempre me incentivarem diariamente com palavras de apoio, de fé, perseverança, pelo exemplo de vida, de amor, de companheirismo e honestidade. Aos meus irmãos Vinícius e Tiago pelo apoio e amizade. A minha prima Magda Patrícia e seu esposo Marcus Aliverti que foram um os maiores incentivadores do meu ingresso ao mestrado, que acreditaram antes de mim, me apoiaram e me acolheram para que eu pudesse realizar essa conquista. Aos meus amados avós Zaíra Pinto e Manoel Pinto (em memória), Luiz Fonseca (em memória) e Lulu Fonseca (em memória), que sempre me incentivaram aos estudos e me ensinaram o valor da família como alicerce. A toda minha família Rosário e Fleury que sempre torceram e rezaram por mim.

Ao meu namorado Wilson dos Santos pelo companheirismo, paciência e apoio em todos os momentos. 
A família Durand Santos, em especial à Dona Iolanda, Seu Santos, Tia Lúcia e Nélida, que me acolheram em Brasília como parte da família, com todo amor, carinho e zelo. Foram anjos que Deus pôs em minha vida, que me apoiaram e cuidaram de mim.

Aos meus amigos e anjos Adriane Dias, Anne Relvas, Ariela Fonseca, Daniel Valencia, Nielde Prado, Norma Mendes, Patrícia Bonolo e Robson Costa que me ajudaram dividindo comigo seu tempo, conhecimentos e experiências acadêmicas, e me apoiando nos momentos difíceis. Agradeço principalmente pela amizade.

Aos meus queridos amigos de mestrado da turma de 2014, em especial a Anne Relvas, Nielde Prado, Daniel Valencia, Andréia de Almeida, Patrícia Bonolo, Gilliard Nunes, pela amizade, dias e noites de estudos, lanches da tarde, risadas, e tudo mais que passamos juntos.

A Marcilene, Junior, Boy, Carla, Sara e Manuela por todo o apoio e atenção quando necessário.

À Companhia de Saneamento Ambiental do Distrito Federal (CAESB), especificamente a engenheira Lucilene Ferreira da ETE-Norte, por colaborar com a pesquisa.

Agradeço ao Conselho Nacional de Desenvolvimento científico e Tecnológico - CNPq, pela ajuda financeira por meio da bolsa de estudos.

A todos que fizeram parte dessa etapa da minha vida, direta ou indiretamente.

Meus mais sinceros agradecimentos. 


\section{RESUMO}

\section{APLICAÇÃO DO SISTEMA COMBINADO POR FILTRO ANAERÓBIO SEGUIDO DE BIOFILTRO AERADO SUBMERSO AO TRATAMENTO DE ESGOTOS SANITÁRIOS DE UNIDADES RESIDENCIAIS UNIFAMILIARES.}

Metade da população brasileira não possui rede de coleta de esgoto, contaminando solos, rios, mananciais e praias, com impacto direto à saúde pública, causando inúmeras doenças, entre elas a diarreia, hepatite A e poliomielite, atingindo todas as idades, porém as crianças são as mais afetadas. Frente a essa realidade foi idealizado um sistema combinado de tratamento de esgotos construído em escala de bancada, por Filtro Anaeróbio (FAn) seguido de Biofiltro Aerado Submerso (BAS), cujos volumes útil foi de aproximadamente 20 litros e 9 litros, respectivamente, utilizando como meio suporte espuma de poliuretano envolta em anel de polipropileno, o sistema foi operado por um período de 115 dias e teve o seu desempenho avaliado ao tratar água residuária sintética (ARS) simulando um esgoto sanitário, proveniente de tanque imhoff, de uma unidade residencial unifamiliar. Durante a fase de partida, inicialmente, o sistema operou com vazão média de $0,02 \mathrm{~m}^{3} / \mathrm{d}$, e teve aumentada a vazão para $0,04 \mathrm{~m}^{3} / \mathrm{d}$ na fase de equilíbrio dinâmico. Na fase estabilizada, que teve duração de 67 dias, o sistema operou com Taxa de Aplicação Superficial (TAS) de 0,6 e $1,3 \mathrm{~m}^{3} / \mathrm{m}^{2}$.d, no FAn e BAS, respectivamente, e apresentou eficiência global média de remoção de 97\% de $\mathrm{DBO}$ s com concentração média do efluente de $12 \mathrm{mg} / \mathrm{L}, 94 \%$ de DQO com concentração média do efluente de $30 \mathrm{mg} / \mathrm{L}, 89 \%$ de SST com concentração média do efluente de $6 \mathrm{mg} / \mathrm{L}, 100 \%$ de SSed, 94\% de nitrogênio total com concentração média do efluente de $4 \mathrm{mg} / \mathrm{L}$. A produção de lodo foi estimada em $0,03 \mathrm{kgSST} / \mathrm{KgDQO}_{\text {aplicada }}$ para o FAn e 0,06 kgSST/KgDQO ${ }_{\text {aplicada }}$ para BAS. O efluente desse sistema combinado de tratamento de esgotos, nas condições em que operou, apresentou redução da produção de lodo e atendeu as condições e padrões de Temperatura, pH, DBO, SST e SSed previstos pela legislação brasileira, podendo ser lançado em corpos d'água. Portanto, o sistema combinado de tratamento de esgotos por FAn seguido de BAS, com meio suporte constituído por espuma de poliuretano envolta em anel de polipropileno, se mostrou uma alternativa eficiente para tratamento de esgoto doméstico unifamiliar, previamente tratado por tanque imhoff.

PALAVRAS-CHAVE: Sistema combinado de tratamento de esgotos; redução da produção de lodo, filtro anaeróbio, biofiltro aerado submerso. 


\section{ABSTRACT}

\section{APPLICATION OF A COMBINED SYSTEM COMPOSED BY ANAEROBIC FILTER FOLLOWED BY SUBMERGED AERATED BIOFILTER TO THE TREATMENT OF SANITARY SEWAGE FROM HOUSEHOLDS.}

Half of the Brazilian population does not have a available sewerage system, defiling soil, rivers, springs and beaches, with direct impact on public health, causing numerous diseases, like diarrhea, hepatitis A and poliomyelitis, reaching all ages, although children are the most affected. Facing this situation, it was designed a combined system of sewerage treatment built in bench scale, A combined treatment system composed by Anaerobic Filter (AnF) followed by Submerged Aerated Biofilter (BAS) was conceived, dimensioned and built in bench scale, using a support consisted of polyurethane foam wrapped by polypropylene ring. This combined system was operated and had evaluated its performance when treating synthetic wastewater simulating sewage from a household (SWW). This treatment system was monitored for 115 days. During the inoculation phase, this system initially operated with a $0.02 \mathrm{~m}^{3} / \mathrm{d}$ flow rate, and, after this, with $0.04 \mathrm{~m}^{3} / \mathrm{d}$, during the stabilized phase. During the stabilized phase, which lasted 67 days, the system operated with a 0.6 and $1.3 \mathrm{~m}^{3} / \mathrm{m}^{2} . \mathrm{d}$ TAS, in AnF and BAS respectively, and obtained an average global efficiency of $\mathrm{BOD}_{5}$ removal of $97 \%$ with an effluent average concentration of 12 $\mathrm{mg} / \mathrm{L}, 94 \%$ of COD removal with an effluent average concentration of $30 \mathrm{mg} / \mathrm{L}, 89 \%$ of TSS removal with an effluent average concentration of $6 \mathrm{mg} / \mathrm{L}, 100 \%$ of SSed. The production of sludge was estimated in $0.03 \mathrm{kgSST} / \mathrm{kgCOD}$ for the $\mathrm{AnF}$ and 0.06 $\mathrm{kgSST} / \mathrm{kgCOD}$ for the BAS. This combined sewage treatment system presented low sludge production and reached the limits of sanitary sewage release in water bodies to analyzed characteristics of Temperature, $\mathrm{pH}, \mathrm{COD}, \mathrm{BOD}$, TSS and SSed, considering the Brazilian standards for waterbodies protection. Therefore, the combined treatment system composed by Anaerobic Filter (AnF) followed by Submerged Aerated Biofilter (BAS) has shown to be an efficient alternative to the treatment of domestic sewage from households, previously treated by imhoff tank.

KEYWORDS: Combined System for Sewage Treatment; Sludge production reduction, Anaerobic Filter, Submerged Aerated Biofilter. 


\section{SUMÁRIO}

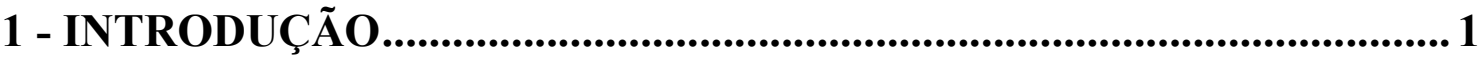

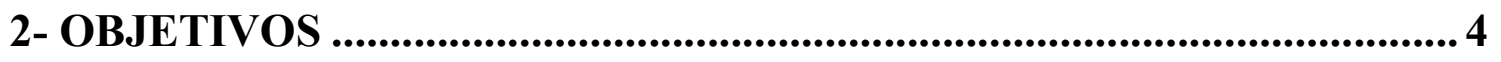

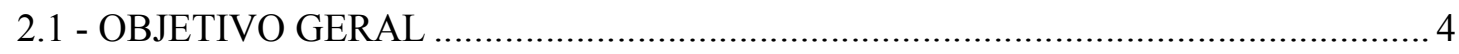

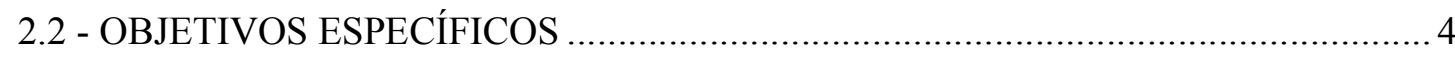

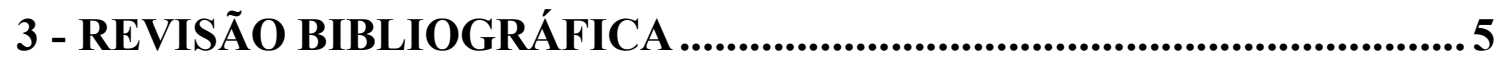

3.1 - SANEAMENTO BÁSICO NO BRASIL ............................................................ 5

3.2 - FILTROS BIOLÓGICOS ANAERÓBIOS .......................................................... 7

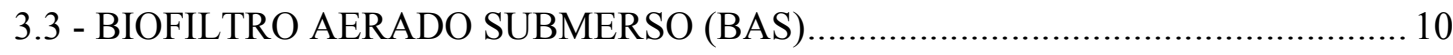

3.3.1 - Concepção do Biofiltro Aerado Submerso........................................................... 12

3.3.1.1 - Sentido de escoamento hidráulico (ar e água) ............................................. 12

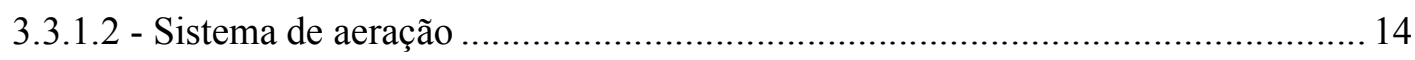

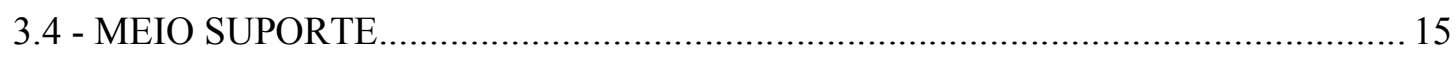

3.5 - TRATAMENTO DE ESGOTO DOMÉSTICO DESCENTRALIZADO .................. 16

3.6 - AVALIAÇÃO DE DESEMPENHO NO TRATAMENTO DE ESGOTO E PADRÕES PARA LANÇAMENTO DE EFLUENTES LÍQUIDOS .............................. 19

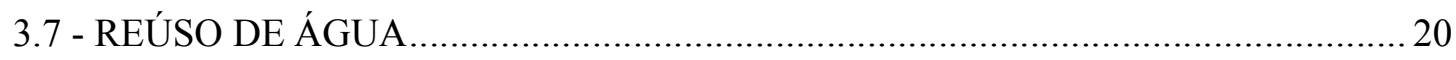

3.8 - EXPERIÊNCIAS NO TRATAMENTO DE ESGOTO DOMÉSTICO COM SISTEMAS COMBINADOS ANAERÓBIO SEGUIDO DE AERÓBIO. ........................ 23

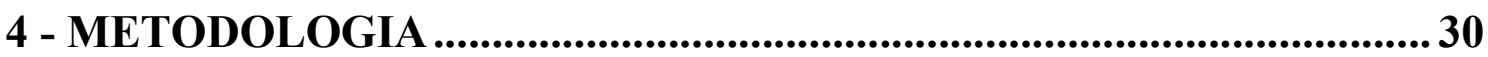

4.1 - CONCEPÇÃO DO PROJETO DE TRATAMENTO DE ESGOTOS COMPOSTO PELOS PROCESSOS FILTRO ANAERÓBIO SEGUIDO DE BIOFILTRO AERADO

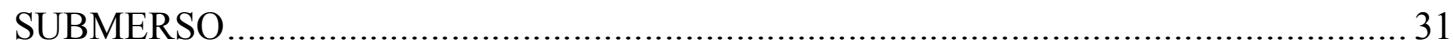

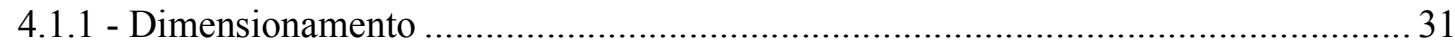

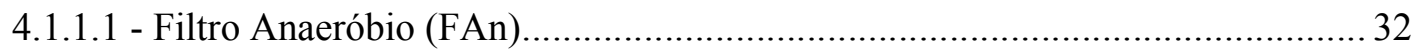

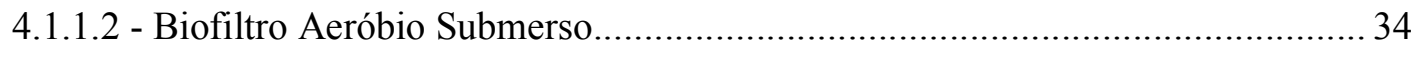

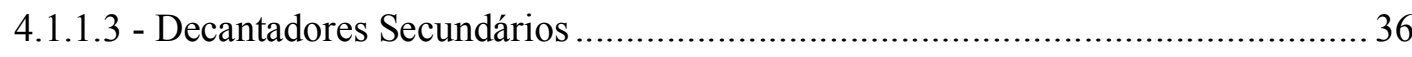


4.1.1.4 - Sistema combinado por Filtro Anaeróbio seguido de Biofiltro aerado submerso

4.2 - CONSTRUÇÃO E INSTALAÇÃO DO MODELO DE ESCALA DE BANCADA DO SISTEMA DE TRATAMENTO DE ESGOTOS COMPOSTO PELOS PROCESSOS DE FILTRO ANAERÓBIO SEGUIDO DE FILTRO AERÓBIO ............... 38

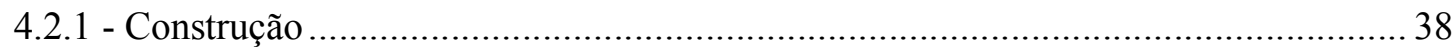

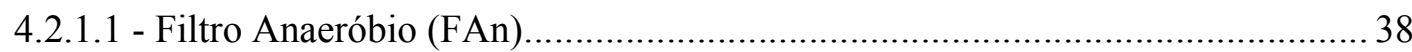

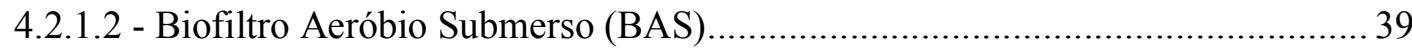

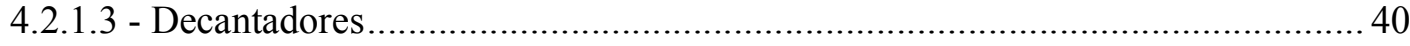

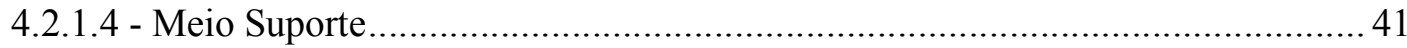

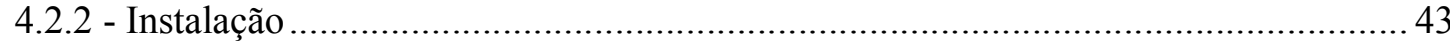

4.3 - OPERAÇÃO, MANUTENÇÃO, CONTROLE E MONITORAMENTO DO SISTEMA DE TRATAMENTO DE ESGOTOS COMPOSTO PELOS PROCESSOS DE FILTRO ANAERÓBIO SEGUIDO DE BIOFILTRO AERADO SUBMERSO........... 43

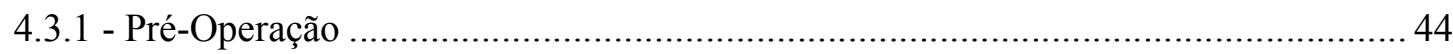

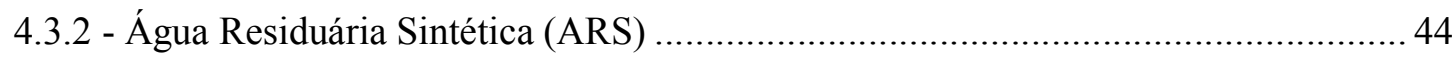

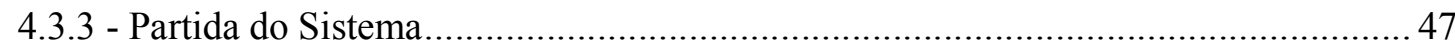

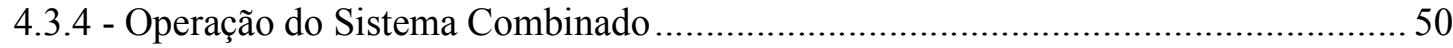

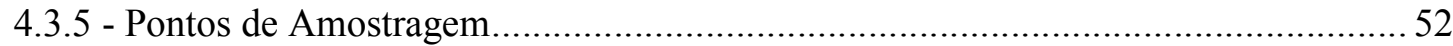

4.3.6 - Caracterização Quantitativa e Qualitativa da Biomassa ......................................... 53

4.3.6.1 - Quantificação da biomassa aderida ao meio suporte do Filtro Anaeróbio e do Biofiltro Aeróbio Submerso 53

4.3.6.2 - Quantificação da biomassa em suspensão do Filtro Anaeróbio e Biofiltro

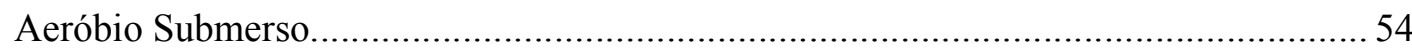

4.3.6.3 - Análise Microbiológica do Biofiltro Aeróbio Submerso ................................ 55

4.3.7 - Produção de Lodo Gerado pelo Sistema Combinado ............................................ 56

4.4 - ANÁLISE E DISCUSSÃO DOS RESULTADOS OBTIDOS. ................................... 57

5 - RESULTADOS E DISCUSSÃO...........................................................58

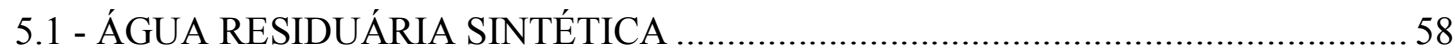

5.2 - AVALIAÇÃO DO DESEMPENHO DO SISTEMA DURANTE A PARTIDA......... 61

5.3 - Avaliação do Desempenho do Sistema Combinado após a Partida.............................. 64

5.3.1 - Avaliação Geral das Condições Ambientais ............................................................ 66

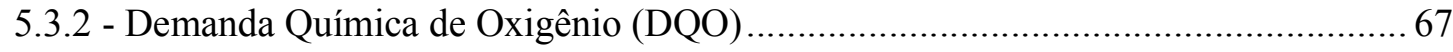




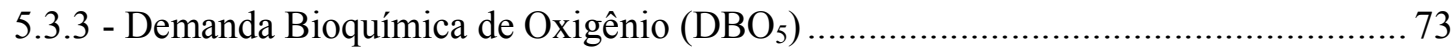

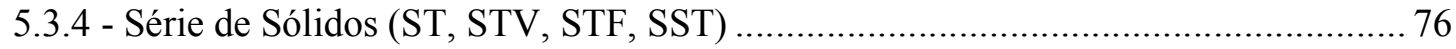

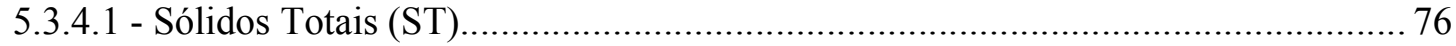

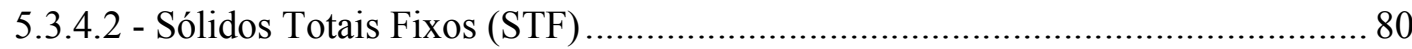

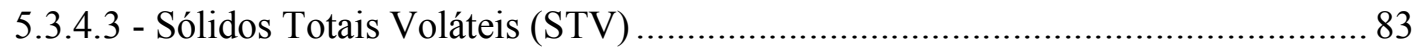

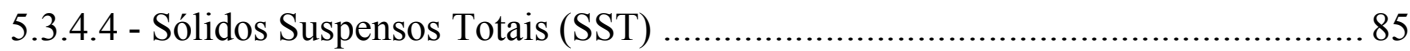

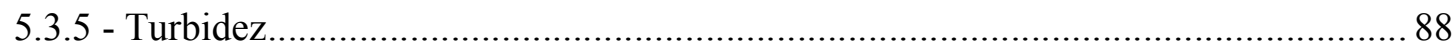

5.3.6 - Caracterização Quantitativa e Qualitativa da Biomassa ....................................... 89

5.3.6.1 - Quantificação da biomassa em suspensão e aderida ao meio suporte do Filtro Anaeróbio e do Biofiltro Aeróbio Submerso................................................................. 89

5.3.6.2 - Análise Microbiológica no Biofiltro Aeróbio Submerso. ................................ 91

5.4 - AVALIAÇÃO DO SISTEMA COMBINADO QUANTO À PRODUÇÃO DE LODO 93

5.5 - Atendimento ao Padrão Nacional de Lançamento de Efluentes Líquidos e Reúso de

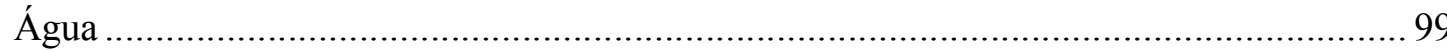

6 - CONCLUSÕES E RECOMENDAÇÕES.......................................... 102

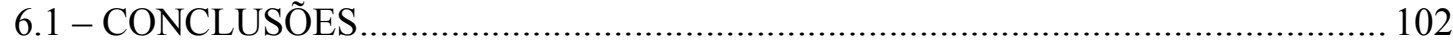

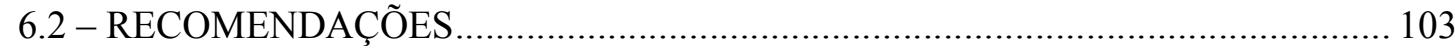

REFERÊNCIAS BIBLIOGRÁFICAS ...................................................... 105 


\section{LISTA DE TABELAS}

Tabela 3.1: Instrumentos Legais de lançamento de efluentes domésticos em corpos d'água.

Tabela 3.2: Tipos de reúso de águas residuais domésticas que têm sido empregados no mundo e seus respectivos obstáculos. 22

Tabela 3.3: Classificação e valores de parâmetros para reuso ........................................23

Tabela 3.4: Condições operacionais adotadas para os reatores UASB e o BF ..................24

Tabela 4.1: Composição da Água Residuária Sintética. ...............................................45

Tabela 4.2: Composição da Solução de Micronutrientes..................................................46

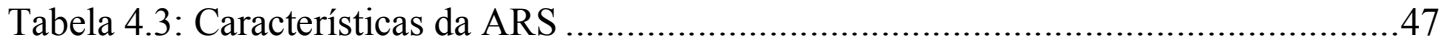

Tabela 4.4: Caracterização do lodo da ETEB-Norte .....................................................48

Tabela 4.5: Condições desejáveis para estabilização do sistema. ....................................49

Tabela 4.6: Parâmetros, métodos e frequência das análises durante a partida do sistema...50

Tabela 4.7: Parâmetros, métodos e frequência das análises durante a avaliação de

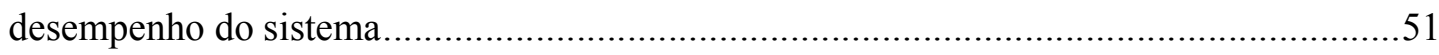

Tabela 5.1: Concentrações da série de sólidos presentes na ARS...................................59

Tabela 5.2: Características do esgoto doméstico unifamiliar, previamente tratado por Tanque Imhoff Modificado e da Água Residuária Sintética..........................................60

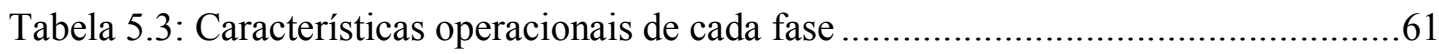

Tabela 5.4: Média, valores máximos e valores mínimos dos parâmetros relevantes a fase 2

Tabela 5.5: Características de avaliação de desempenho global do sistema combinado.....64

Tabela 5.6: Variação dos valores obtidos para os parâmetros empregados na avaliação do

Sistema. .65 
Tabela 5.7: Quantificação de Sólidos Sedimentados Recirculado. (N=8) .66

Tabela 5.8: Concentrações de OD no BAS e no FAn. $(\mathrm{N}=10)$.

Tabela 5.9: Resultados das concentrações de DQO nos seis pontos coletados. $(\mathrm{N}=13)$.....68

Tabela 5.10: Resultados das concentrações de $\mathrm{DBO}_{5}$ nos seis pontos coletados. $(\mathrm{N}=7) \ldots .73$

Tabela 5.11: Resultado das concentrações de ST das dez análises nos seis pontos coletados. $(\mathrm{N}=10)$. .77

Tabela 5.12: Resultado das concentrações de STF. $(\mathrm{N}=10)$ .80

Tabela 5.13: Resultado das concentrações de STV. $(\mathrm{N}=10)$. 83

Tabela 5.14: Resultados das concentrações de SST. $(\mathrm{N}=10)$. .85

Tabela 5.15: Resultados das análises de ST e STV realizadas no FAn e no BAS. .89

Tabela 5.16: Média do peso da biomassa aderida ao FAn, realizada em 5 conjunto de 10 unidades de meio suporte.

Tabela 5.17: Média do peso da biomassa aderida ao BAS, realizada em 5 conjunto de 10 unidades de meio suporte.

Tabela 5.18: Produção de lodo e eficiências de remoção de DQO e SST, obtidas em diferentes sistemas combinados.

Tabela 5.19: Produção de lodo e eficiências de remoção de DQO e SST, obtidas em

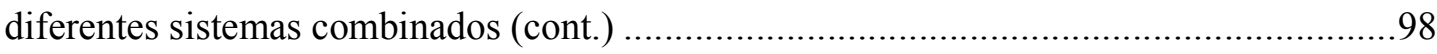

Tabela 5.20: Resultado do sistema combinado comparado aos padrões de lançamento.....99

Tabela 5.21: Características do Efluente final. 100

Tabela 5.22: Concentração de nutrientes nas irrigações com esgoto tratado - PROSAB 5 


\section{LISTA DE FIGURAS}

Figura 3.1: Domicílios com Saneamento inadequado. .5

Figura 3.2: Sentidos de fluxo hidráulico (ar/ líquido) em reatores aeróbios com biofilme (a) co-corrente (b) contra-corrente. Fonte: Gonçalves et al. (2001)......................................13

Figura 3.3: Características da tecnologia mais adequada ...............................................18

Figura 4.1: Diagrama simplificado da metodologia ......................................................

Figura 4.2: Dimensões do Filtro Anaeróbio (FAn). Unidade em metros, sem escala..........34

Figura 4.3: Biofiltro Aerado Submerso (BAS). Unidade em metros, sem escala...............35

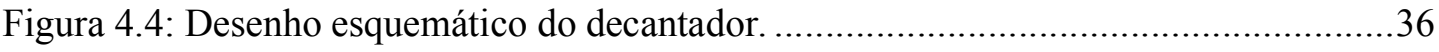

Figura 4.5: Sistema Combinado de Filtro anaeróbio (FAn) seguido do Biofiltro Aerado

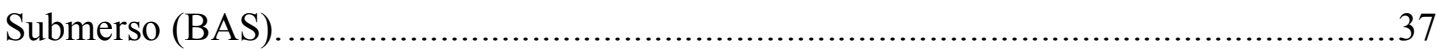

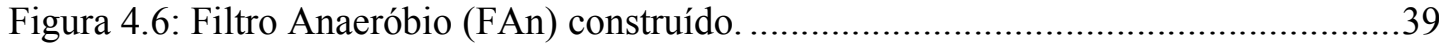

Figura 4.7: (a) Vista frontal do Biofiltro aeróbio submerso (BAS) e (b) Vista superior do BAS. .40

Figura 4.8: Decantadores (a) Dec 1; (b) Dec 2; (c) Vista superior do decantador ..............41

Figura 4.9: Meio suporte de espuma de poliuretano envolta do bob...............................42

Figura 4.10: Meio suporte armazenado em bolsa de nylon ........................................42

Figura 4.11: Sistema experimental construído e instalado.............................................43

Figura 4.12: Vista superior do Filtro Anaeróbio em teste de operação ..............................44

Figura 4.13: Lodo Utilizado para a Inoculação ..........................................................48

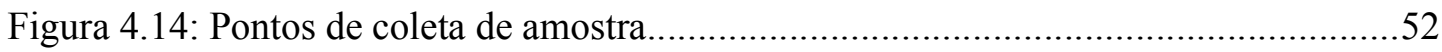

Figura 4.15: Amostras de meio suporte com biomassa aderida ...................................53

Figura 4.16: Amostras da biomassa em suspensão retiradas do fundo do FAn. .................54

Figura 4.17: Raspagem manual com o auxílio de escovas de uso odontológico ................55 
Figura 5.1: Gráfico do comportamento das eficiências de remoção de DQO nos efluentes de cada filtro, e do sistema combinado, ao longo do período de operação .62

Figura 5.2: Análise de sólidos sedimentáveis do lodo do Dec 2 ....................................64

Figura 5.3: Concentrações de DQO bruta obtidas no afluente e efluente do FAn. .69

Figura 5.4: Concentrações de DQO bruta obtidas no afluente (BAS-A) e efluente (BAS-E) do BAS.

Figura 5.5: Concentrações de DQO bruta obtidas no sistema combinado FAn-BAS. .........70

Figura 5.6: Box-plot das concentrações de DQO bruta. 71

Figura 5.7: Eficiências de DQO bruta nos efluentes de cada filtro, e do sistema combinado, durante o monitoramento após a partida. .71

Figura 5.8: Box-plot do resultado da eficiência de DQO bruta.........................................72

Figura 5.9: Perfil de variação (Comportamento da DBO). .............................................74

Figura 5.10: Box-Plot das concentrações de DBO.......................................................74

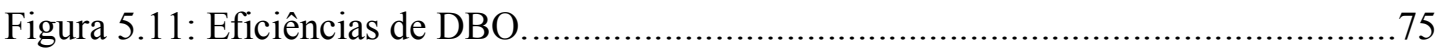

Figura 5.12: Box-Plot do resultado das eficiências de DBO ...........................................76

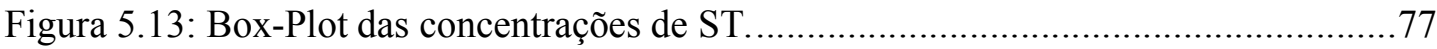

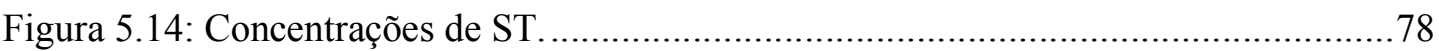

Figura 5.15: Gráfico de eficiência de remoção de ST ......................................................78

Figura 5.16: Gráfico comparativo das eficiências de remoção de ST do sistema. ( $\mathrm{N}=10) . .79$

Figura 5.17: Box-plot das eficiências de remoção de ST...............................................79

Figura 5.18: Gráfico Box-plot das concentrações de STF ........................................... 81

Figura 5.19: Gráfico comparativo das eficiências obtidas ao longo do sistema. ................81

Figura 5.20: Gráfico comparativo das eficiências de remoção de STF. $(\mathrm{N}=10) \ldots \ldots \ldots \ldots \ldots . . .82$

Figura 5.21: Box-plot das eficiências de remoção de STF ...........................................82 
Figura 5.22: Gráfico Box-plot das concentrações de STV. 83

Figura 5.23: Gráfico comparativo das eficiências de remoção de STV. $(\mathrm{N}=10)$..............84

Figura 5.24: Gráfico das eficiências de remoção de STV ................................................84

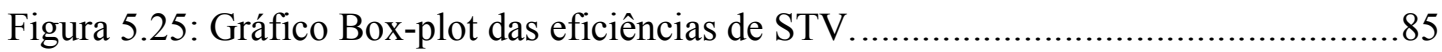

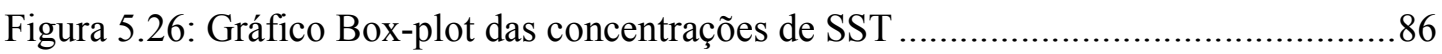

Figura 5.27: Gráfico comparativo da eficiência de remoção de SST ................................87

Figura 5.28: Box-plot das eficiências de remoção de SST ........................................... 87

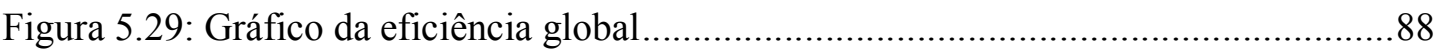

Figura 5.30: Concentrações de turbidez no efluente final..............................................89

Figura 5.31: Comparação das concentrações de sólidos totais e voláteis obtidas em cada

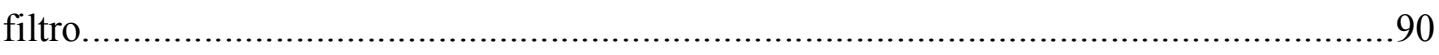

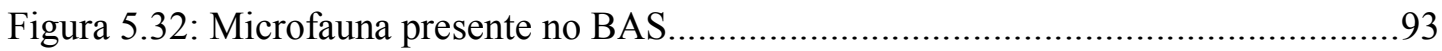




\section{LISTA DE EQUAÇÕES}

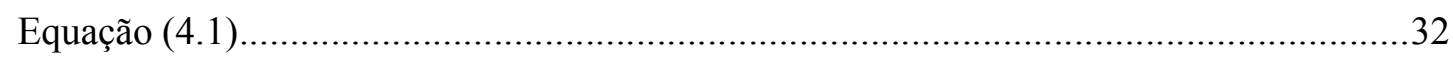

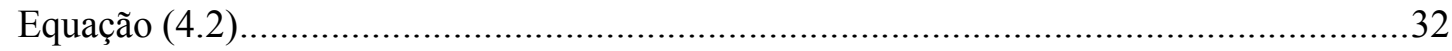

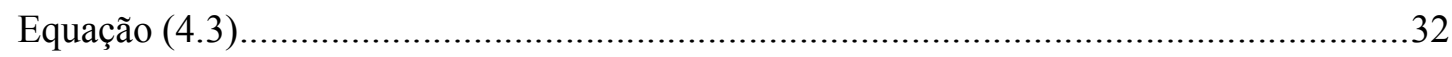

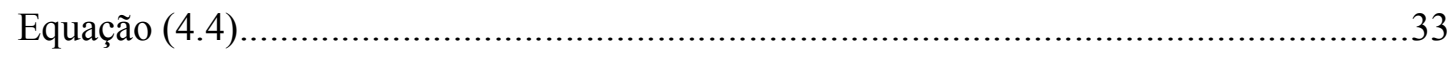

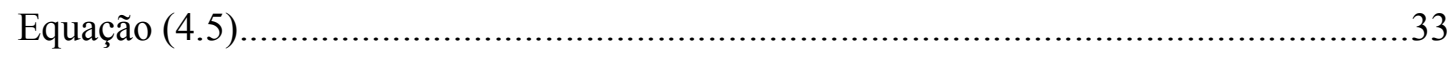

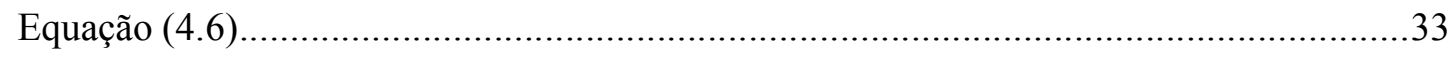

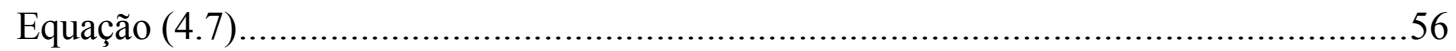

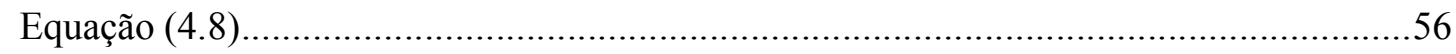

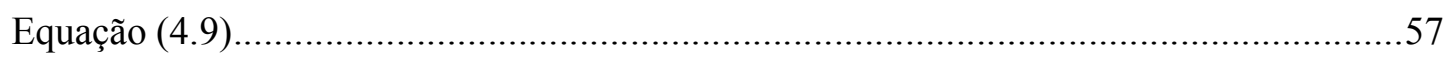

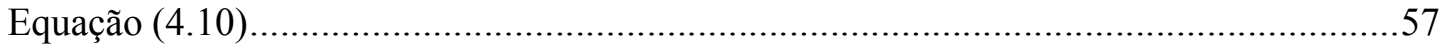




\section{LISTA DE SIGLAS}

\begin{tabular}{|c|c|}
\hline ABNT & Associação Brasileira de Normas Técnicas \\
\hline ARS & Água Residuária Sintética \\
\hline BAS & Biofiltro Aeróbio Submerso \\
\hline BAS-A & Biofiltro Aeróbio Submerso - Afluente \\
\hline BAS-E & Biofiltro Aeróbio Submerso - Efluente \\
\hline $\mathrm{BF}$ & Filtro Biológico aerado submerso \\
\hline $\mathrm{CNRH}$ & Conselho Nacional de Recursos Hídricos \\
\hline CONAMA & Conselho Nacional do Meio Ambiente \\
\hline $\mathrm{COV}$ & Carga Orgânica Volumétrica \\
\hline CTO & Carbono Orgânico Total \\
\hline DBO & Demanda Bioquímica de Oxigênio \\
\hline DQO & Demanda Química de Oxigênio \\
\hline ETE & Estação de Tratamento de Esgoto \\
\hline IBGE & Instituto Brasileiro de Geografia e Estatística \\
\hline FAn & Filtro Anaeróbio \\
\hline FAn-A & Filtro Anaeróbio - Afluente \\
\hline FAn-E & Filtro Anaeróbio - Efluente \\
\hline FBP & Filtro Biológico Percolador \\
\hline FFB & Biorreatores de Filme Fixo \\
\hline NBR & Norma Brasileira \\
\hline NTK & Nitrogênio Total Kjeldahl \\
\hline
\end{tabular}




\begin{tabular}{|c|c|}
\hline $\mathrm{O} \& \mathrm{G}$ & Óleos e Graxas \\
\hline $\mathrm{pH}$ & Potencial Hidrogeniônico \\
\hline PNRH & Política Nacional de Recursos Hídricos \\
\hline PNSB & Pesquisa Nacional de Saneamento Básico \\
\hline PROSAB & Programa de Pesquisa em Saneamento Básico \\
\hline PTARH & Programa de Pós-Graduação em Tecnologia Ambiental e Recursos Hídricos \\
\hline PVC & Policloreto de Polivinila \\
\hline $\mathrm{RBC}$ & Reator Biológico de Contato \\
\hline SNGRH & Sistema Nacional de Gerenciamento de Recursos Hídricos \\
\hline SNIS & Sistema Nacional de Informações sobre Saneamento \\
\hline SST & Sólidos Suspensos Totais \\
\hline SSed & Sólidos Sedimentáveis \\
\hline ST & Sólidos Totais \\
\hline STF & Sólidos Totais Fixos \\
\hline STV & Sólidos Totais Voláteis \\
\hline TCO & Taxa de Carregamento Orgânico \\
\hline UASB & Upflow Anaerobic Sludge Blanket \\
\hline UTFPR & Universidade Tecnológica Federal do Paraná \\
\hline
\end{tabular}




\section{1 - INTRODUÇÃO}

No Brasil, há um grande déficit no serviço de coleta de esgoto, e um déficit maior ainda quando se trata de tratamento de esgoto, resultando na precariedade ou ausência do esgotamento sanitário nos municípios. Segundo dados do Sistema Nacional de Informações sobre Saneamento (SNIS), apenas 49,8\% dos municípios brasileiros tinham serviço de esgotamento sanitário por rede coletora, e deste montante apenas 40,8\% faziam o tratamento do esgoto coletado em 2014, sendo que o Distrito Federal aponta 82,11\% em rede coletora de esgotos e 70,61\% em tratamento, apresentando um dos melhores índices em coleta e tratamento de esgoto. Há uma grande disparidade entre as regiões em relação a coleta e tratamento de esgoto, enquanto algumas regiões avançam para universalização da água e esgotos uma grande parte do Brasil não avança. Um exemplo é a disparidade existente entre as regiões Norte e Sudeste, onde no Pará apenas 5,35\% da população tem acesso a rede coletora de esgoto sendo que 2,03\% do esgoto gerado é submetido ao tratamento, já em São Paulo a rede de coleta atende 88,05\% e 56,24\% do esgoto é tratado (SNIS, 2016).

Essa deficiência reflete diretamente no lançamento de esgoto bruto em condições impróprias. Diversos municípios brasileiros lançam esse resíduo em rios, lagos ou lagoas, mar e utilizam ao mesmo tempo esses corpos receptores para vários usos a jusante, como o abastecimento de água, a recreação, a irrigação e a aquicultura. Entre estes municípios, uma parcela, lança o esgoto não tratado nos corpos hídricos e os utilizam a jusante para a irrigação, e/ou os usam para o abastecimento humano, gerando um custo extra para o tratamento desta água, além dos impactos ao meio ambiente e a saúde pública.

Ações de saneamento podem evitar danos ao ambiente, especialmente aos solos e corpos hídricos, melhorando a qualidade do efluente tratado, podendo então contribuir para melhorar a saúde e o bem-estar da população.

A Resolução No 430 do Conselho Nacional do Meio Ambiente (CONAMA), de 2011, “dispõe sobre as condições e padrões para lançamento de efluentes de sistemas de tratamento de esgotos sanitários" e em seu artigo 21, trata do lançamento direto de 
efluentes oriundos de sistemas de tratamento de esgotos sanitários, em que deverão ser obedecidas algumas condições e padrões específicos.

As áreas rurais, aglomerados urbanos, de maneira geral famílias de baixa renda são os mais afetados pela carência no esgotamento sanitário, principalmente no norte e nordeste. Essa parcela da população está disposta a um saneamento básico precário, ou seja, com sistema de coleta e tratamento de esgoto inexistente ou impróprio, ficando mais suscetível as doenças de veiculação hídrica, como a poliomielite, hepatite A, giardíase, disenteria amebiana, diarréia por vírus, febre tifóide, febre paratifoide, diarréias e disenterias bacterianas (como a cólera), ancilostomíase (amarelão), ascaridíase (lombriga), teníase, cisticercose, filariose (elefantíase), esquistossomose, entre outras.

Frente a essa realidade do país, e visando inserir essa parcela da população que está mais distante dos sistemas de coleta e tratamento centralizados de esgoto, se fazem necessárias mais pesquisas em sistemas de tratamento de esgoto com as seguintes características: baixo custo de implantação e operação, baixo requisito de energia, simplicidade operacional, baixo requisito de área, baixa produção de lodo e eficiência adequada para atendimento às normas ambientais.

A associação de sistemas de tratamento anaeróbio e aeróbio representa uma alternativa viável para sistemas combinados de tratamento, sendo o reator anaeróbio a unidade de prétratamento, que possibilita a redução de tamanho e do consumo de energia do conjunto e oferece condições de digerir o lodo aeróbio excedente. Neste caso, se tem um volume total de reatores muito menor e mantém-se a qualidade do efluente em patamares elevados pelo pós-tratamento realizado na fase aeróbia (Coura e Van Haandel, 1999).

Os processos anaeróbios apresentam como vantagens a baixa produção de sólidos (lodo) que é mais baixa que em processos aeróbios, como lodos ativados ou filtros biológicos, tolerância a elevadas cargas orgânicas, a tecnologia é relativamente simples, com baixo consumo de energia e baixo custo operacional. Entretanto, esses processos têm como principais desvantagens a produção de um efluente com matéria carbonácea e nitrogenada em concentrações elevadas para o lançamento direto em corpos d'água. 
Quando o tratamento aeróbio é utilizado em combinação com o processo anaeróbio, ele complementa a remoção da matéria orgânica remanescente do processo anaeróbio, consumindo menos oxigênio, devido à menor carga orgânica afluente, gerando menor quantidade de lodo e, consequentemente utilizando menos energia elétrica, minimizando os custos de operação, além, do favorecimento da remoção e conversão de nitrogênio e fósforo (Castagnato, 2006).

Tendo em vista a precariedade sanitária do Brasil, principalmente nas comunidades mais afastadas dos centros urbanos e mais carentes de recursos financeiros, buscou-se criar um sistema de tratamento de esgoto unifamiliar que possa tratar de forma eficiente e com baixa geração de lodo, atendendo ao padrão de lançamento de esgoto sanitário e requisitos locais. Desta forma, o presente trabalho se justifica pelo fato de que existem populações isoladas e periféricas que não são atendidas por nenhum sistema de tratamento de esgotos ou são atendidas por sistemas precários. Além disso, as pesquisas científicas voltadas para este tipo de tecnologia, sistemas de tratamento descentralizados, ainda têm muito a avançar.

Este trabalho apresenta um estudo realizado para o tratamento descentralizado de esgoto doméstico, por meio de um sistema combinado, que tenha a possibilidade de ser concebido de forma compacta, com baixo custo, operação simplificada, cuja finalidade foi testar e avaliar a eficiência desse tipo de sistema, composto por um filtro anaeróbio seguido de um biofiltro aeróbio submerso, em escala de bancada, utilizando como meio suporte espuma de poliuretano envolta por anel de polipropileno (bob). 


\section{2- OBJETIVOS}

\section{1 - OBJETIVO GERAL}

Avaliar um sistema de tratamento de esgoto composto pela combinação de filtro anaeróbio seguido de biofiltro aerado submerso para o tratamento de água residuária sintética simulando o esgoto proveniente de unidades residenciais unifamiliares, previamente tratado por um reator biológico anaeróbio, tendo especial atenção na redução da geração de lodo.

\section{2 - OBJETIVOS ESPECÍFICOS}

(1) Avaliar o desempenho do sistema combinado composto por filtro anaeróbio seguido de um biofiltro aerado submerso, no tratamento de água residuária sintética simulando um esgoto de residência unifamiliar;

(2) Verificar a redução da geração de lodo pelo sistema combinado de filtro anaeróbio seguido de um biofiltro aerado submerso, comparado ao tratamento biológico anaeróbio e aeróbio trabalhando isoladamente

(3) Avaliar qualitativamente a comunidade zooplanctônica colonizadora do biofiltro submerso aerobio. 


\section{3 - REVISÃO BIBLIOGRÁFICA}

\section{1 - SANEAMENTO BÁSICO NO BRASIL}

A Lei Federal n ${ }^{\circ} 11.445 / 2007$, que estabeleceu diretrizes para o saneamento básico, define saneamento básico como o conjunto de serviços, infraestruturas e instalações de abastecimento de água, esgotamento sanitário, limpeza urbana e manejo de resíduos sólidos e drenagem de águas pluviais urbanas.

O Instituto Brasileiro de Geografia e Estatística - IBGE aponta que 30,5\% do total dos municípios lançam inadequadamente esgoto não tratado em rios, lagos ou lagoas, e utilizam estes corpos receptores para vários usos a jusante, como, por exemplo, para o abastecimento de água, a recreação, a irrigação e a aquicultura. Constatou-se ainda que entre estes municípios, $23 \%$ lançam o esgoto não tratado nos corpos hídricos e os utilizam a jusante para a irrigação, e 16\% os usam para o abastecimento humano. Encarecendo o tratamento da água para o abastecimento e expondo as pessoas a doenças, entre outros impactos. Na Figura 3.1 é apresentado o percentual de domicílios, por estados, com saneamento inadequado, nos anos de 2000 e 2010.

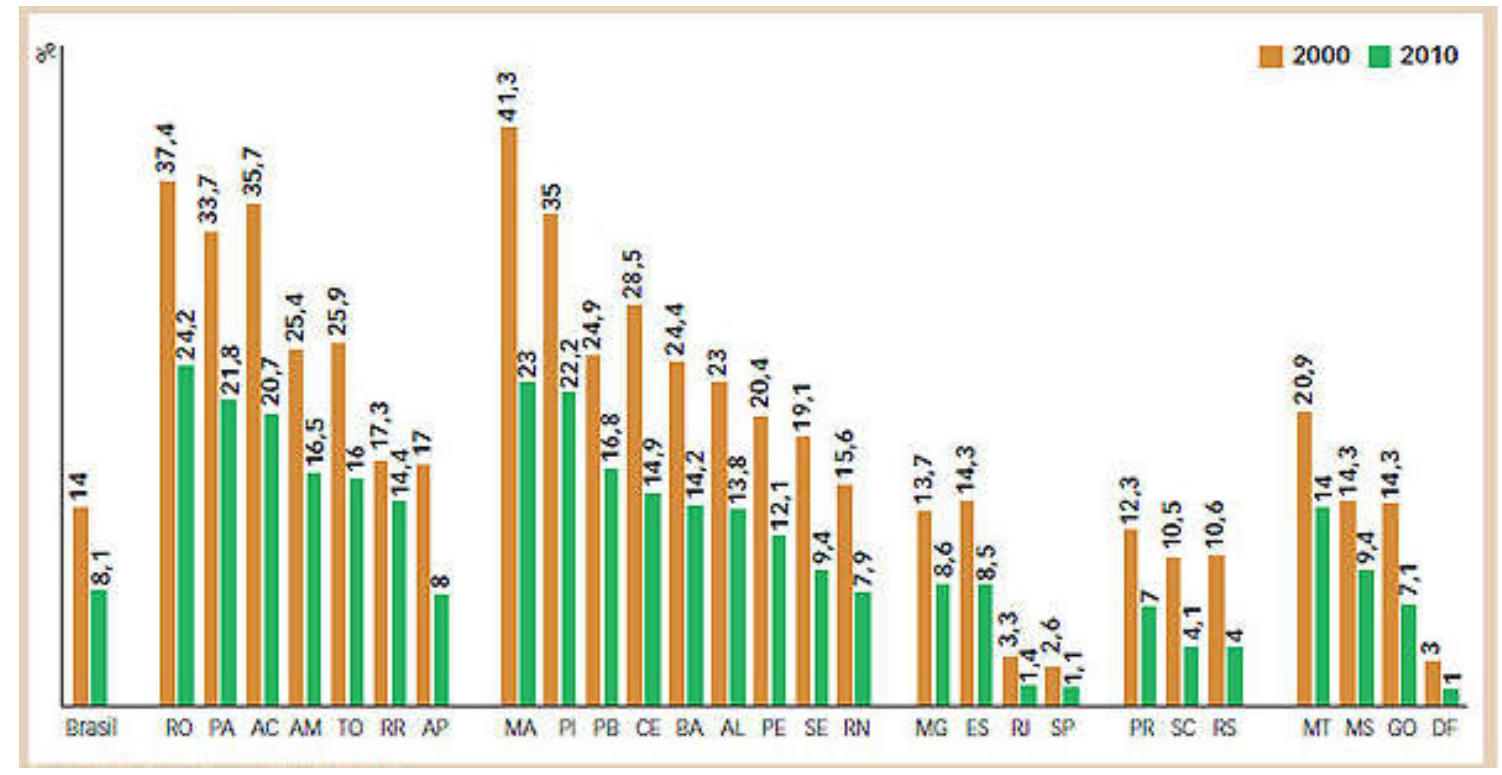

Figura 3.1: Domicílios com Saneamento inadequado.

Fonte: IBGE, Censo Demográfico 2000/2010. 
O termo saneamento ambiental abrange aspectos que vão além do saneamento básico, englobando o abastecimento de água potável, a coleta, o tratamento e a disposição final dos esgotos e dos resíduos sólidos e gasosos, os demais serviços de limpeza urbana, a drenagem urbana, o controle ambiental de vetores e reservatórios de doenças, a disciplina da ocupação e de uso da terra e obras especializadas para proteção e melhoria das condições de vida (IBGE, 2011).

Dados atualizados pelo SNIS, em 2014, apontam que 67,3\% dos municípios brasileiros utilizam as fossas sépticas/sumidouros como solução alternativa de esgotamento sanitário, com maior número de municípios adeptos nas Regiões Nordeste e Sul. Os municípios que utilizam a fossa rudimentar correspondem a 19,77\%, 3\% dos municípios brasileiros utilizam como alternativa o lançamento seu esgoto em valas a céu aberto, 3,9\% usam como alternativa o lançamento em cursos d'água, 4,18\% em galerias de águas pluviais e 1,64\% utilizam outras alternativas.

A Região Sudeste mantém um percentual elevado de seus municípios com coleta de esgoto, 78,3\%. A Região Norte é a que apresenta a menor proporção de municípios com coleta (7,9\%), seguida da Região Nordeste $(23,8 \%)$, da Região Sul $(38,1 \%)$ e da CentroOeste (46,9\%) (SNIS, 2016).

A Pesquisa Nacional de Saneamento Básico - PNSB (2008) revelou que 44\% dos municípios brasileiros que possuem rede coletora estão investindo em melhorias do sistema de esgotamento sanitário. Esse número, embora baixo, representa um aumento nos investimentos no setor se comparado com os dados apresentados na pesquisa de 2000 , segundo a qual apenas 30,3\% dos municípios investiam em melhorias ou ampliações de seu sistema de esgotamento sanitário. A maioria desses municípios, 38,7\%, está investindo em melhorias nas redes coletoras, seguido pelo número de municípios que investiram nas ligações prediais, $34,6 \%$.

Porém, um longo caminho ainda precisa ser percorrido, uma vez que apenas $13,7 \%$ dos municípios estão investindo em melhorias ou ampliações em suas estações de tratamento. Além disso, os dados revelam que em quase todas as regiões cresceu a proporção de municípios investindo em melhorias na sua rede de esgotamento sanitário, com exceção da 
Região Norte, que teve um decréscimo na proporção de municípios investindo em melhorias, se comparado com os dados de 2000.

De acordo com os dados estatísticos, observa-se que há uma precariedade nos serviços de coleta e de tratamento do esgoto entre os municípios brasileiros. O tratamento de esgoto gerados está mais presente nas regiões do Sudeste e Centro-Oeste, sendo que esta tem o maior percentual de esgoto tratado, com $46,4 \%$, seguida pela região Sudeste com 45,7 \% e Sul $36,9 \%$, o Nordeste trata apenas $31,4 \%$, a região com pior índice é a região Norte com apenas 14,4\% (SNIS, 2016).

Dessa forma, faz-se necessária a busca pela universalização dos serviços de saneamento básico e de aumentar sua qualidade, de modo a contribuir para melhorar a saúde e o bemestar da população.

Logo, para minimizar os impactos causados pela má gestão e precariedade no tratamento de esgoto doméstico, e visando a uma solução de tratamento para atender a população necessitada, observou-se a necessidade de entender melhor e realizar mais pesquisas no âmbito de tratamento de esgoto doméstico descentralizado com baixa geração de lodo.

\section{2 - FILTROS BIOLÓGICOS ANAERÓBIOS}

Os filtros anaeróbios para tratamento de esgoto são utilizados no Brasil desde a década de 1950, mas com a revisão, realizada em 1982, pela ABNT (Associação Brasileira de Normas Técnicas), da norma sobre Construção e Instalação de Fossas Sépticas e Disposição dos Efluentes Finais, tornou-se mais difundido no país. Esta norma, NBR 7229/82, apresenta diretrizes básicas para projeto e construção de filtros anaeróbios utilizados como pós-tratamento de efluentes de tanques sépticos.

Esta revisão da norma foi de fundamental importância para difundir o uso deste modelo no país, porém constatou-se em diversos trabalhos realizados que o modelo de filtro anaeróbio recomendado pela norma apresenta vários problemas operacionais, principalmente devido à dificuldade de remoção do excesso de lodo acumulado na câmara inferior de entrada, o que gerou várias discussões a respeito e estudos para melhorar tal tecnologia. 
Em 1997, a ABNT publicou a NBR 13969 com o título “Tanques Sépticos - Unidades de Tratamento Complementar e Disposição Final dos Efluentes Líquidos - Projeto, Construção e Operação", apresentando modelos de filtros anaeróbios de fluxo ascendente mais detalhados e com recomendações relativas aos aspectos operacionais.

Segundo Busato (2004), a crescente aceitação dos processos anaeróbios como principal unidade de tratamento biológico de esgoto deve-se, principalmente, à constatação de que uma parte considerável do material orgânico (em geral próximo de $70 \%$ ) pode ser removida nessa unidade, utilizando-se tecnologia simples e de baixo custo, com reduzido consumo de energia, sem necessidade da adição de produtos químicos e com produção de lodo em pequena quantidade e já estabilizado.

De modo geral, pode-se dizer que o tratamento no filtro anaeróbio ascendente é um processo pelo qual o efluente passa por uma massa de sólidos biológicos, biofiltro, que está agregada a um meio suporte dentro do reator. O meio suporte pode ser de pedra britada, blocos cerâmicos, anéis plásticos, escórias de alto forno, esferas de polietileno, bambu, onde a biomassa fica aderida.

O filtro ascendente fica submerso e os espaços vazios existentes entre o meio suporte são preenchidos com o efluente líquido. O meio suporte deve ocupar entre 50 e $70 \%$ de profundidade do filtro.

Ávila (2005) e Castagnato (2006) conceituam o filtro anaeróbio como uma unidade preenchida com um material suporte inerte com elevado grau de vazios que permite a passagem do líquido em seu interior. O material de enchimento serve como suporte para os microrganismos, que aderem à superfície desse material, formando o biofilme e propiciando alta retenção de biomassa no reator.

Quando os filtros anaeróbios são utilizados para pós-tratamento de outras unidades anaeróbias, além de complementar o tratamento, sua capacidade de reter sólidos e de recuperar-se de sobrecargas qualitativas e quantitativas confere elevada segurança operacional ao sistema e maior estabilidade ao efluente, mantendo as vantagens do 
tratamento anaeróbio - produz pouco lodo, não consome energia, tem operação simples e baixo custo (Andrade Neto et al., 2002).

O efluente oriundo dos filtros anaeróbios geralmente é clarificado e com boa parte da matéria orgânica removida, em torno de $70 \%$. No entanto, sua eficiência depende da atividade biológica que está associada diretamente à temperatura, ao tempo de detenção hidráulica (TDH) e ao tempo de detenção celular ou tempo de retenção dos sólidos biológicos dentro do reator (Chernicharo, 2001).

O efluente de um filtro anaeróbio é muito adequado para a disposição no solo, seja para infiltração ou para irrigação com fins produtivos. As baixas concentrações de sólidos suspensos também facilitam a desinfecção por processos físicos ou químicos. Porém, os reatores anaeróbios não removem satisfatoriamente microrganismos patogênicos nem nutrientes (Andrade Neto et al., 2002).

Segundo Chernicharo (2001), os filtros anaeróbios podem ter várias formas, configurações e dimensões, desde que se obtenha um fluxo bem distribuído através do leito. Os mais usuais têm fluxo ascendente ou descendente. Nos filtros de fluxo ascendente, o leito é necessariamente submerso (afogado). Os de fluxo descendente podem trabalhar afogados ou não.

A disposição e forma do material suporte, além da distribuição uniforme do efluente dentro do reator, são fatores muito importantes para que não ocorram caminhos preferenciais do líquido evitando o comprometimento do desempenho do reator.

A passagem do esgoto pelos interstícios do reator já proporciona a mistura necessária para que ocorra o contato com a biomassa. Mas podem ocorrer entupimentos devido ao crescimento excessivo dos microrganismos, por sua má distribuição dentro do filtro ou pelos sólidos afluentes que nele se acumulam. Por isso, os filtros anaeróbios são mais indicados para o tratamento de efluentes que contenham sólidos solúveis e material suspenso de pequenas dimensões, como é o caso dos esgotos sanitários que já passaram por um tratamento preliminar (Kato et al., 1999). 
Comparados a outros sistemas de tratamento de efluentes, os filtros anaeróbios apresentam várias vantagens, que são as seguintes, segundo Young \& McCarty (1969) apud Castagnato (2006).

- Não há necessidade de promover a recirculação de efluente ou de sólidos no sistema;

- O acúmulo de alta concentração de biomassa ativa dentro do reator possibilita o tratamento de efluentes com baixa carga orgânica em temperatura ambiente, sem a necessidade do fornecimento de calor para atingir uma boa eficiência do sistema;

- A geração de lodo é muito pequena;

- Suportam altas cargas orgânicas;

- Demandam baixo custo operacional;

- Seu desempenho é menos dependente das variações do afluente;

- Geram efluentes com qualidade e com baixo teor de sólidos;

- Sua construção e operação são relativamente simples.

Porém, algumas desvantagens na utilização desta tecnologia podem ser apontadas, como, a possibilidade de obstrução dos interstícios - colmatação ou entupimento do leito - a necessidade de um volume maior devido ao espaço ocupado pelo meio suporte; além de custos adicionais.

\section{3 - BIOFILTRO AERADO SUBMERSO (BAS)}

O BAS, que é a tecnologia avaliada neste trabalho, é conceitualmente um reator de alta taxa, no qual o tratamento biológico do esgoto é realizado por micro-organismos aderidos a um meio suporte inerte (recheio). Esse reator tem como principal característica a superposição dos processos de eliminação biológica de poluentes e de filtração de partículas em suspensão no esgoto (Gonçalves et al., 2001).

Essa biomassa, aderida aos recheios, forma o biofilme, que é responsável por aumentar o tempo de retenção dos sólidos (ou idade do lodo), tornando o sistema mais resistente a choques de cargas hidráulicas e orgânicas. 
Em linhas gerais, o BAS é um tanque preenchido com um material poroso, através do qual esgoto e ar fluem permanentemente. Na quase totalidade dos processos existentes, o meio poroso é mantido sob total imersão pelo fluxo hidráulico, caracterizando-os como reatores trifásicos compostos por:

- Fase sólida: constituída pelo meio suporte e pelas colônias de microrganismos que nele se desenvolvem, sob a forma de um filme biológico (biofilme);

- Fase líquida: composta pelo líquido em permanente escoamento através do meio poroso;

- Fase gasosa: formada pela aeração artificial e, em reduzida escala, pelos gases gerados pela atividade biológica.

Segundo Gonçalves et al. (1997), as principais características dos biofiltros aerados submersos são: compacidade, alta concentração de biomassa ativa no volume reacional, idade do lodo elevada, pequena produção de lodo, resistência aos choques (hidráulicos e de carga orgânica) e possibilidade de cobertura evitando problemas com odores e impacto visual.

O BAS trata-se de um reator de leito fixo contendo, no fundo, equipamentos aeradores para uma eficiente remoção de carga nitrogenada e orgânica residual. O processo tem apresentado boa aceitação, principalmente por não necessitar de uso de clarificadores como tratamento posterior. Há necessidade de retro-lavagem para remoção dos sólidos retidos no leito, os quais, inclusive, podem vir a danificar os equipamentos aeradores (Domingues, 2005).

No Brasil, na maioria das vezes, associados em série a reatores do tipo UASB, os biofiltros aerados submersos vêm recentemente sendo utilizados como solução para o tratamento de esgotos em pequenos e médios municípios. Com inúmeras simplificações com relação aos processos similares aos utilizados na Europa, os novos biofiltros surgidos no Brasil podem ser utilizados em ETEs compactas, com baixos custos de implantação, operação e manutenção, que não demandam mão-de-obra qualificada e apresentam baixo consumo energético e produção de lodos (Gonçalves, 2001). 
Martins (2014) avaliou o desempenho de um Biofiltro Aerado Submerso (BAS), usando como recheio do reator o Biobob ${ }^{\circledR}$, o efluente sanitário tratado era proveniente do campus de Londrina da Universidade Tecnológica Federal do Paraná (UTFPR). No sistema, o ar foi injetado no BAS por meio de uma bomba tipo aquário e a recirculação do efluente realizada por meio de bomba. Martins (2014) concluiu que o sistema foi satisfatório, apresentou eficiência de remoção do $\mathrm{N}_{\text {amoniacal }}$ de entre 60 e $70 \%$ e uma taxa de nitrificação volumétrica média de $0,01704 \mathrm{kgN} \cdot \mathrm{m}^{-3} \cdot \mathrm{dia}^{-1}$.

Visando obter melhor eficiência do BAS para o tratamento de esgoto doméstico, é preciso considerar alguns aspectos para a concepção do reator, como a escolha do sentido do escoamento hidráulico, tipo de material a ser usado como meio suporte e qual o sistema de aeração mais adequado.

\subsection{1 - Concepção do Biofiltro Aerado Submerso}

Os aspectos tecnológicos mais importantes para a diferenciação das diversas configurações de biofiltros é o sentido de escoamento hidráulico; o tipo de material suporte e o sistema de aeração.

\subsubsection{1 - Sentido de escoamento hidráulico (ar e água)}

Gonçalves et al. (2001) defendem que o sentido de fluxo hidráulico (ar e água) determina as principais características operacionais de um BAS, influenciando diretamente nos seguintes pontos: retenção de SS, transferência gás - líquido de $\mathrm{O}_{2}$, evolução da perda de carga hidráulica, tipo de lavagem, gastos energéticos e a produção de odores. As diferentes opções para o sentido de fluxo hidráulico são apresentadas na Figura 3.2. O fluxo de ar nos BAS só é viável no sentido ascendente, devido ao estado de permanente imersão do meio suporte. A corrente descendente de ar só é possível em meios granulares que não sejam submersos (caso dos filtros biológicos percoladores), o que limita as opções para o fluxo hidráulico em BAS a fluxo co-corrente, com fluxos de ar e líquido ascendentes, e contracorrente, com fluxo de líquido descendente e ar ascendente. 


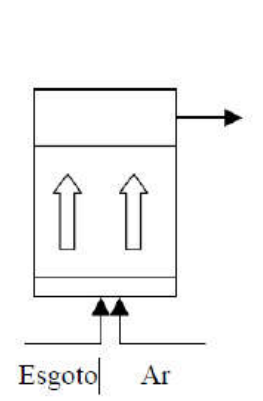

(a)

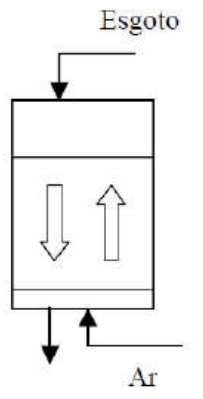

(b)

Figura 3.2: Sentidos de fluxo hidráulico (ar/ líquido) em reatores aeróbios com biofilme (a) co-corrente (b) contra-corrente. Fonte: Gonçalves et al. (2001).

Os diferentes processos são geralmente caracterizados com base no sentido de fluxo hidráulico: ascendente ou descendente. As principais vantagens e desvantagens de cada uma destas opções são relacionadas a seguir.

- Capacidade de retenção de sólidos: A capacidade de captura de sólidos suspensos é maior nos processos descendentes com meio granular pesado $(d>1)$ ou ascendentes com meio flutuante $(\mathrm{d}<1)$. Neste caso, o fluxo de líquido se dá no sentido da compressão do leito filtrante, conferindo-lhe grande capacidade de filtração. Por outro lado, nos processos ascendentes com meio suporte pesado, o fluxo cocorrente produz uma expansão do leito filtrante, permitindo uma retenção de sólidos suspensos melhor distribuída ao longo da altura do BAS. BAS com suporte estruturado necessitam de uma decantação secundária, pois possuem pequena capacidade de captura e estocagem de sólidos suspensos;

- Evolução da perda de carga: Devido à elevada efíciência na retenção de sólidos suspensos, a perda de carga evolui mais rapidamente nos BAS descendentes com leito granular pesado e nos BAS ascendentes com meio flutuante. Com uma evolução da perda de carga relativamente menos acentuada, os processos ascendentes com material pesado possuem leitos com altura podendo atingir até 3,00 m. A evolução da perda de carga é extremamente reduzida nos meios suportes estruturados, com carreiras de filtração podendo durar vários dias;

- Comportamento hidráulico: Os processos descendentes (contra-corrente) podem favorecer a formação de bolhas de ar aprisionado no seio do meio granular (embolia). A desvantagem dos processos ascendentes estaria na possibilidade de 
haver má distribuição do afluente no meio granular, gerando curtos circuitos e queda de rendimento de depuração do BAS;

- Detalhes construtivos: Nos processos descendentes, a tubulação de aeração só entra em contato com o esgoto tratado, sendo menos sujeita a entupimentos por sólidos presentes no esgoto decantado. Já no caso dos processos ascendentes, somente o esgoto tratado entra em contato com a atmosfera, eliminando problemas de odores. Os BAS ascendentes podem ainda ser autolimpantes, quando a lavagem for realizada no sentido contra-corrente.

\subsubsection{2 - Sistema de aeração}

A situação mais comum é o BAS possuir sistema direto de aeração, composto por sopradores e tubulações para o transporte de ar. Outra opção é a utilização de uma câmara de saturação, na qual o esgoto e o ar são mantidos sob pressão por alguns minutos, aumentando a solubilidade do ar no meio líquido (Fontana, 2007).

Ryhiner et al. (1992) apud Godoy (2007) estudaram a influência da taxa de aeração na eficiência de um BAS, no tratamento de esgoto sanitário, com meio suporte estruturado, verificando que quanto maior a taxa de aeração maior será a remoção de matéria orgânica, portanto, maior a eficiência do mesmo. Também concluíram que, com o aumento da taxa de aeração, ocorreu um incremento de turbulência no meio filtrante, provocando uma diminuição na resistência à transferência de massa, tanto entre gás e líquido como entre líquido e sólido, influenciando na atividade microbiológica do biofilme.

Para taxas de aeração de 10 a $40 \mathrm{Nm}^{3}$ ar/ $\mathrm{kgDBO}$ aplicada, as eficiências de transferência de $\mathrm{O}_{2}$ variaram de 9,2 e $5 \%$. O consumo médio de oxigênio calculado neste experimento foi de $0,5 \mathrm{~kg} \mathrm{O}_{2} / \mathrm{kgDBO}$ aplicada, sensivelmente inferior aos característicos dos lodos ativados convencionais (0,8 a $1,2 \mathrm{~kg} \mathrm{O}_{2} / \mathrm{kgDBO}$ aplicada) (Gonçalves et al., 2001).

Gonçalves et al. (2001) afirmam ainda que no caso dos biofiltros, o fornecimento de ar para atender às necessidades do oxigênio do processo aeróbio para se ter um efluente com DBO na faixa de 20 a $30 \mathrm{mg} / \mathrm{L}$, não nitrificado, é de cerca de 35 a $40 \mathrm{~m}^{3}$.ar/ kgDBO aplicada. 
Sitônio (2001) constatou em seu experimento que o sistema de difusão de ar através de pedras porosas não foi eficiente, com a formação de caminhos preferenciais e zonas mortas. Nesta ocasião, a autora sugeriu a utilização de uma câmara de saturação para melhor distribuição do oxigênio no interior do reator.

De Carvalho Jr. (2004) realizou experimentos com BAS injetando ar no reator tanto por câmara de saturação quanto por sistema de aeração. O autor concluiu que a câmara de saturação utilizada em sua pesquisa não atendeu a demanda de oxigênio dissolvido necessária à manutenção de condições de aerobiose no reator. A injeção de ar direto no leito do BAS, além de fornecer melhores resultados, também melhorou o desprendimento do excesso de biomassa que era descartado do sistema durante as lavagens do leito.

\section{4 - MEIO SUPORTE}

A seleção do meio suporte é uma etapa crítica no projeto e operação de um filtro. O meio suporte deve cumprir duas funções: servir de suporte para a fixação dos microrganismos e reter fisicamente os sólidos suspensos presentes no esgoto (Della Giustina, 2009).

O material de enchimento deve ser inerte, não-biodegradável e indeformável, para que conserve suas características de forma e de granulometria durante vários anos de operação da estação.

Segundo Jordão \& Pessoa (2005), as propriedades físicas são fatores importantes na seleção do meio suporte, principalmente pelas seguintes razões.

- O material deverá ser inerte e rígido, não afetado por reações químicas e desgastes excessivos;

- As dimensões influenciam na seleção do material devido aos valores da superfície específica e do volume de vazios, e consequentemente do volume útil;

- O peso unitário influi diretamente no cálculo estrutural, no transporte e no manuseio;

- A área superficial específica influi na capacidade de reter a biomassa e no desempenho do processo; 
- O volume de vazios é o fator preponderante na manutenção das condições aeróbias do processo devido ao suprimento de oxigênio em excesso através da circulação de ar.

Gonçalves et al. (2001) destacam as seguintes características para um material suporte ideal.

- Apresentar resistência estrutural suficiente para suportar seu próprio peso e o peso da biomassa aderida à superfície;

- Apresentar o menor custo possível por unidade de matéria orgânica removida, quando utilizado em tratamento em nível secundário;

- Apresentar alta superfície específica e alta rugosidade.

De acordo com Andrade Neto et al. (1999) as finalidades do material filtrante são as seguintes.

- Permitir acúmulo de grande quantidade de biomassa, com o consequente aumento do tempo de retenção celular;

- Melhorar o contato entre os constituintes do despejo afluente e os sólidos biológicos contidos no reator;

- Atuar como uma barreira física, evitando que os sólidos sejam carreados para fora do sistema de tratamento; e

- Ajudar a promover a uniformização do escoamento no reator.

\section{5 - TRATAMENTO DE ESGOTO DOMÉSTICO DESCENTRALIZADO}

A coexistência entre os sistemas centralizados e descentralizados visa a ampliar a acessibilidade da população brasileira ao sistema de coleta e tratamento de esgoto doméstico. A gestão descentralizada de tratamento de esgoto doméstico oferece-se como uma alternativa viável diante do difícil acesso à rede pública de esgoto, da inexistência de sistemas centralizados ou de existência de municípios com baixa densidade populacional, por exemplo. 
O sistema de tratamento centralizado é o sistema de tratamento de água residuária doméstica convencional utilizado no Brasil, responsável pela coleta, tratamento e destinação do efluente tratado geralmente longe do ponto de origem. Ele demanda grandes investimentos econômicos, sendo um sistema de grande porte, que necessita de mão de obra especializada, operação e manutenção, dificultando a difusão deste sistema para comunidades rurais (Massoud et al., 2009).

O tratamento descentralizado tem-se mostrado como uma alternativa ao tratamento das águas residuárias domésticas. O efluente é tratado próximo ao local de geração, se mostrando como uma maneira sustentável de gerenciamento de esgotos domésticos, possibilitando a utilização do efluente na própria comunidade. Existem diversos sistemas de tratamento que, se construídos, operados e mantidos adequadamente, produzem efluente passível de utilização, reduzindo assim efeitos negativos para o meio ambiente e para a saúde pública (Massoud et al., 2009).

Os sistemas descentralizados são sistemas que atendem ao tratamento de efluentes provenientes de residências, bairros e pequenas comunidades que não tem acesso ao tratamento centralizado. O tratamento descentralizado caracteriza-se por ser de baixo custo de implantação e operação, baixo requisito de energia, simplicidade operacional, não requerendo mão de obra especializada, baixo requisito de área, baixa produção de lodo e eficiência adequada para atendimento às normas ambientais quanto ao lançamento e reúso do efluente tratado (Massoud et al., 2009).

Segundo Massoud et al. (2009) a escolha da tecnologia mais adequada para o tratamento descentralizado de esgoto doméstico requer cuidados, reduzindo o risco de problemas futuros e fracassos do sistema. Apresentam a acessibilidade e a adequação como as duas questões-chave na escolha de uma tecnologia de tratamento. A acessibilidade diz respeito às condições econômicas da comunidade, enquanto a adequação diz respeito às condições ambientais e sociais. Na Figura 3.3 estão apresentados os diferentes fatores que afetam a seleção da tecnologia mais apropriada.

Chernicharo (2001) afirma que o baixo custo, simplicidade operacional, baixa produção de lodo e as condições ambientais do Brasil, como a predominância de temperaturas elevadas, 
tem sido características favoráveis a difusão de sistemas anaeróbios em tratamento descentralizado de esgoto doméstico. Porém, o efluente desse tipo de sistema apresenta concentrações residuais ainda elevadas de matéria orgânica (em termo de DQO e DBO), microrganismos patogênicos e nutrientes.

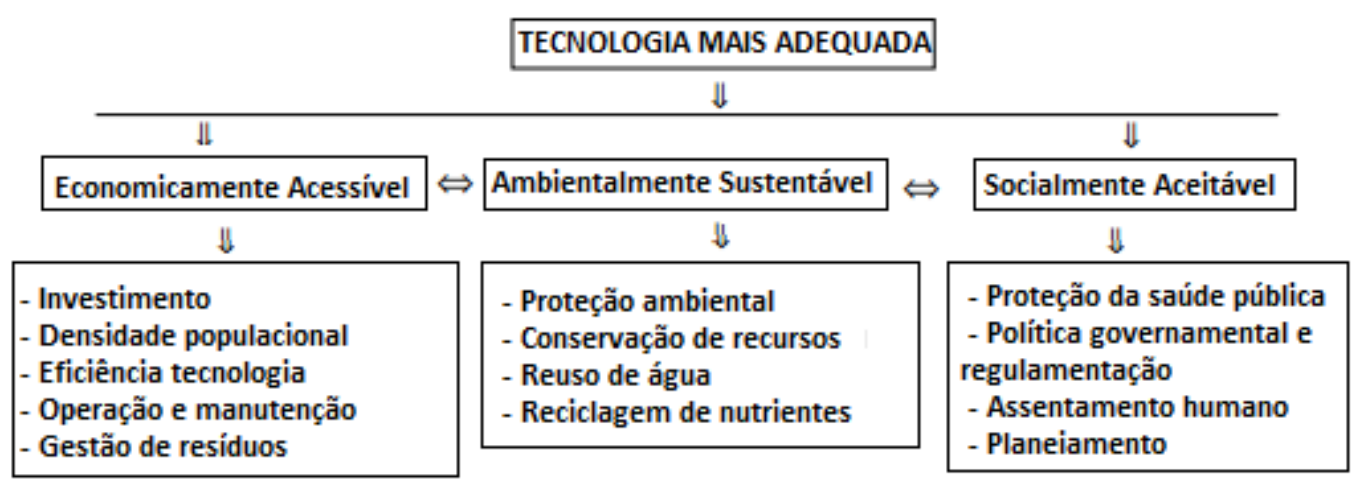

Figura 3.3: Características da tecnologia mais adequada

Fonte: Massoud et al., 2009.

Os custos da gestão de um sistema de tratamento descentralizado são mais baixos, pois concentram-se na unidade de tratamento, o próprio gerador é o responsável pelo sistema. Porém, o desempenho do sistema depende de manutenção e inspeção regulares.

Naphi (2004) cita como vantagens do sistema descentralizados, a possibilidade de empregar diferentes estratégias de gestão financeira e estratégias eco eficientes, utilização de tecnologias com menos investimentos em manutenção, efluente unicamente doméstico, não há mistura com outros tipos de efluentes, como o industrial.

USEPA (2004) classifica o sistema descentralizado de esgotos domésticos como:

- No local - coleta, transporta, trata, destina ou utiliza as águas residuárias provenientes de uma única residência ou edifício. Subdivididos em sistemas:

- Comunidade - são utilizados para coletar e tratar águas residuárias de uma comunidade.

○ Familiares - são utilizados para coletar e tratar águas resdiuárias unifamiliares. 
- Em grupo - coleta as águas residuárias provenientes de duas ou mais residências ou edifícios, transportando-os para um local adequado para seu tratamento e disposição final.

\section{6 - AVALIAÇÃO DE DESEMPENHO NO TRATAMENTO DE ESGOTO E PADRÕES PARA LANÇAMENTO DE EFLUENTES LÍQUIDOS}

Para avaliar o desempenho de um sistema ou estações de tratamento de esgoto são utilizados alguns critérios, como o modo comparativo, que avalia a eficiência de remoção dos parâmetros como $\mathrm{DBO}_{5}, \mathrm{DQO}, \mathrm{SST}$, coliformes totais e termotolerantes, alcalinidade, $\mathrm{pH}$, óleos e graxas e nutrientes, em relação às pesquisas já realizadas. Outro modo de avaliar o desempenho é verificar o atendimento aos padrões de lançamento de efluentes sanitários tratados previstos pela legislação federal ambiental CONAMA 430/2011, assim como nas específicas de cada estado. A Tabela 3.1 apresenta os instrumentos legais, e seu respectivo estado, assim como a legislação federal que dispõem critérios para lançamento de efluentes domésticos em corpos d'água.

Tabela 3.1: Instrumentos Legais de lançamento de efluentes domésticos em corpos d'água.

\begin{tabular}{|c|c|}
\hline ESTADO & INSTRUMENTO LEGAL \\
\hline BRASIL & CONAMA 430/2011 \\
\hline Alagoas (AL) & Decreto Estadual 6.200 de 01/03/85 \\
\hline Ceará (CE) & Portaria $\mathrm{N}^{\mathrm{o}} 154$ de 22/07/02 \\
\hline Goiás (GO) & $\begin{array}{l}\text { Lei Estadual } \mathrm{N}^{\circ} 8.544 \text { de } 17 / 10 / 78 \text {. Decreto } 1.745 \text { de } \\
06 / 12 / 79\end{array}$ \\
\hline Mato Grosso do Sul (MS) & CECA/MS No 36 de 27/06/12 \\
\hline Mato Grosso (MT) & CONSEMA No 55 de 21/06/12 \\
\hline Minas Gerais (MG) & COPAM /CERH-MG No 01 de 05/05/08 \\
\hline Paraná (PR) & Resolução SEMA No 001/07 de 11/01/07 \\
\hline Rio de Janeiro (RJ) & $\begin{array}{l}\text { Norma técnica FEMA NT 202.R10. Diretriz FEMA } \\
\text { 215.R3 }\end{array}$ \\
\hline Rio Grande do Sul (RS) & Portaria SSMA Nº 05/89 \\
\hline Rondônia (RO) & Decreto Estadual No 7.903 de $01 / 07 / 97$ \\
\hline Santa Catarina (SC) & Decreto Estadual No 14.250 de 05/06/81 \\
\hline São Paulo (SP) & Decreto Estadual No 8.468 de $08 / 09 / 76$ \\
\hline
\end{tabular}




\section{7 - REÚSO DE ÁGUA}

A Lei Federal No 9.433 de 08/01/97, instituiu a Política Nacional de Recursos Hídricos (PNRH) e criou o Sistema Nacional de Gerenciamento de Recursos Hídricos (SNGRH). Um dos objetivos da Política Nacional dos Recursos Hídricos é assegurar à atual e às futuras gerações a disponibilidade de água necessária, em padrões de qualidade adequados aos respectivos usos, o que também justifica a regulamentação de procedimentos para controle da qualidade da água para consumo humano e seu padrão de potabilidade. A Política Nacional de Recursos Hídricos (PNRH) define que a gestão dos recursos hídricos deve ser descentralizada e deverá contar com a participação do Poder Público, dos usuários e das comunidades.

Visando atender a PNRH e diante da escassez dos recursos hídricos e a crescente densidade demográfica o reúso de água torna-se uma política que deve ser seguida tanto pelo setor produtivo quanto pela população, uma vez que a água potável em abundância está sendo tarefa cada vez mais difícil de ser cumprida para o atendimento da população. Como a maioria dos usos da água não requer água potável, a prática do reúso da água visa minimizar os impactos ambiental e econômico, diminuindo o consumo dos recursos hídricos, o valor pago às prestadoras que distribuem água e os insumos no processo de tratabilidade da água para torná-la potável.

A Resolução Federal n 54 do Conselho Nacional de Recursos Hídricos (CNRH) de 2006, que "estabelece modalidades, diretrizes e critérios gerais para a prática de reuso direito não potável de água, e dá outras providências”, considera que o reúso de água se constitui em prática de racionalização e de conservação de recursos hídricos, conforme princípios estabelecidos na Agenda 21, podendo tal prática ser utilizada como instrumento para regular a oferta e a demanda de recursos hídricos. Considera também que a escassez de recursos hídricos observada em certas regiões do território nacional está relacionada aos aspectos de quantidade e de qualidade e à elevação dos custos de tratamento de água em função da degradação de mananciais; que a prática de reúso de água reduz a descarga de poluentes em corpos receptores, conservando os recursos hídricos para o abastecimento público e outros usos mais exigentes quanto à qualidade; que reduz os custos associados à poluição e contribui para a proteção do meio ambiente e da saúde pública. 
Metcalf e Eddy (1991) definem reúso de água como o uso de água residuária tratada para finalidades como irrigação e troca térmica em indústrias. Já o CNRH (2006), defini o reúso da água como a utilização da água residuária, ou seja, todo esgoto, água descartada, efluentes líquidos de edificações, indústrias, agroindústrias e agropecuária, tratados ou não, que atendam aos padrões exigidos para sua utilização nas modalidades desejadas. O reúso direto não potável de água abrange as seguintes modalidades.

- Reúso para fins urbanos: utilização de água de reúso para fins de irrigação paisagística, lavagem de logradouros públicos e veículos, desobstrução de tubulações, construção civil, edificações, combate a incêndio, dentro da área urbana;

- Reúso para fins agrícolas e florestais: aplicação de água de reúso para produção agrícola e cultivo de florestas plantadas;

- Reúso para fins ambientais: utilização de água de reúso para implantação de projetos de recuperação do meio ambiente;

- Reúso para fins industriais: utilização de água de reúso em processos, atividades e operações industriais; e,

- Reúso na aquicultura: utilização de água de reúso para a criação de animais ou cultivo de vegetais aquáticos.

Metcalf e Eddy (2003) classificam o reúso da água nas categorias principais a seguir: irrigação na agricultura; irrigação de parques, escolas, vegetação de estradas, campos destinados a esporte, cemitérios, jardins residenciais, comerciais, industriais; uso industrial e reciclagem: água para resfriamento, caldeiras, processos e construção pesada; Recarga de aquífero; usos racionais e ambientais tais como lagos, pântanos, aumento de fluxos dos rios, lagos para a pesca; usos urbanos não potáveis como água para incêndio e descarga de vasos sanitários; uso potável, adicionadas a reservatórios de suprimento de água e reúso direto destas águas com adequada desinfecção "pipe-to-pipe reuse". Sendo que em cada categoria existem cuidados que devem ser tomados em função da qualidade da água utilizada para reúso.

A Tabela 3.2 ilustra os alguns tipos de reúso de águas residuais domésticas que têm sido empregados no mundo e seus respectivos obstáculos, apresentados por Felizatto (2001). 
Tabela 3.2: Tipos de reúso de águas residuais domésticas que têm sido empregados no mundo e seus respectivos obstáculos.

\begin{tabular}{|c|c|c|}
\hline Categoria & Aplicações & Obstáculos potenciais \\
\hline $\begin{array}{l}\text { Irrigação na } \\
\text { agricultura }\end{array}$ & $\begin{array}{l}\text { Plantio de forrageiras, plantas } \\
\text { fibrosas e grãos, plantas } \\
\text { alimentícias, viveiros de plantas } \\
\begin{array}{l}\text { ornamentais, proteção contra } \\
\text { geadas. }\end{array}\end{array}$ & $\begin{array}{l}\text { Efeitos da qualidade da água, } \\
\text { principalmente no teor de sal e alguns } \\
\text { metais pesados no solo e nas colheitas } \\
\text { Dificuldade de mercado e aceitação } \\
\text { pública do produto. }\end{array}$ \\
\hline $\begin{array}{l}\text { Irrigação } \\
\text { paisagística }\end{array}$ & $\begin{array}{l}\text { Parques, cemitérios, campos de } \\
\text { golfe, faixas de domínio de auto- } \\
\text { estradas, campi universitários, } \\
\text { cinturões verdes, gramados } \\
\text { residenciais. }\end{array}$ & $\begin{array}{l}\text { Preocupação com a saúde pública } \\
\text { relativo a patógenos (bactérias, vírus e } \\
\text { parasitas). Poluição das águas } \\
\text { superficiais e subterrâneas (se não for } \\
\text { apropriadamente administrado). Alto } \\
\text { custo devido a necessidade de grandes } \\
\text { áreas, incluindo as áreas de controle. }\end{array}$ \\
\hline $\begin{array}{l}\text { Usos } \\
\text { ambientais e } \\
\text { recreativos }\end{array}$ & $\begin{array}{l}\text { Represas e lagos ornamentais } \\
\text { para fins recreativos e } \\
\text { desportivos; aumento de vazão } \\
\text { em pântanos, alagados e } \\
\text { indústrias de pesca. }\end{array}$ & $\begin{array}{l}\text { Preocupação com a saúde pública } \\
\text { relativo a patógenos (bactérias, vírus e } \\
\text { parasitas). Eutrofização no lago ou } \\
\text { reservatório devido a Nitrogênio e } \\
\text { Fósforo. Toxicidade para a vida } \\
\text { aquática. Estética incluindo o odor. }\end{array}$ \\
\hline $\begin{array}{l}\text { Usos } \\
\text { urbanos e } \\
\text { não potáveis }\end{array}$ & $\begin{array}{l}\text { Água para combate à incêndio, } \\
\text { descarga de vasos sanitários, } \\
\text { refrigeração de sistemas de ar } \\
\text { condicionado, lavagem em geral } \\
\text { de cidades (de ruas, ponto de } \\
\text { ônibus, etc.). }\end{array}$ & $\begin{array}{l}\text { Preocupação com a saúde pública em } \\
\text { especial com a transmissão via } \\
\text { aerossóis de patógenos. Corrosão e } \\
\text { crescimento microbiológico. }\end{array}$ \\
\hline
\end{tabular}

Já a NBR - 13.969/97 classifica o reúso local de água como a utilização local do esgoto tratado para diversas finalidades, exceto para o consumo humano. E dispõe as classificações e seus respectivos valores de parâmetros para esgotos, conforme o tipo de água, apresentadas na Tabela 3.3. 
Tabela 3.3: Classificação e valores de parâmetros para reuso

\begin{tabular}{|c|c|c|}
\hline & Tipo de uso & Parâmetros \\
\hline Classe I & $\begin{array}{l}\text { - Lavagem de carros e outros } \\
\text { usos que requerem o contato } \\
\text { direto do usuário com a água }\end{array}$ & $\begin{array}{c}\text { Turbidez } \leq 5 \\
\text { SST } \leq 200 \mathrm{mg} / \mathrm{L} \\
\mathrm{Ph} 6 \text { a } 8 \\
\text { Coliforme fecal } \leq 200 \\
\text { NMP/100 mL } \\
\text { Cloro residual } 0,5 \text { a } 1,5 \\
\mathrm{mg} / \mathrm{L}\end{array}$ \\
\hline Classe II & $\begin{array}{l}\text { - Lavagens de pisos, } \\
\text { calçadas e irrigação dos } \\
\text { jardins } \\
\text { - Manutenção dos lagos e } \\
\text { canais para fins } \\
\text { paisagísticos, exceto } \\
\text { chafarizes }\end{array}$ & $\begin{array}{c}\text { Turbidez } \leq 5 \\
\text { Coliforme fecal } \leq 500 \\
\text { NMP } / 100 \mathrm{~mL} \\
\text { Cloro residual } 0,5\end{array}$ \\
\hline Classe III & $\begin{array}{l}\text { - Uso nas descargas dos } \\
\text { vasos sanitários }\end{array}$ & $\begin{array}{c}\text { Turbidez } \leq 10 \\
\text { Coliforme fecal } \leq 500 \\
\text { NMP } / 100 \mathrm{~mL}\end{array}$ \\
\hline Classe IV & $\begin{array}{l}\text { - Uso nos pomares, cereais, } \\
\text { forragens, pastagens para } \\
\text { gados e outros cultivos } \\
\text { através de escoamento } \\
\text { superficial ou por sistema de } \\
\text { irrigação pontual. }^{(1)}\end{array}$ & $\begin{array}{c}\text { Coliforme fecal } \leq 5000 \\
\text { NMP } / 100 \mathrm{~mL} \\
\mathrm{OD} \geq 2,0 \mathrm{mg} / \mathrm{L}\end{array}$ \\
\hline
\end{tabular}

Fonte: NBR-13.969/97

${ }^{(1)}$ As aplicações devem ser interrompidas pelo menos 10 dias antes da colheita.

\section{8 - EXPERIÊNCIAS NO TRATAMENTO DE ESGOTO DOMÉSTICO COM SISTEMAS COMBINADOS ANAERÓBIO SEGUIDO DE AERÓBIO.}

O sistema combinado anaeróbio-aeróbio tem se mostrado uma opção viável quanto aos aspectos econômico e técnico, pois esse sistema pode promover oxidação carbonária, nitrificação, desnitrificação. Portanto, essa combinação torna possível aproveitar as vantagens de cada processo e minimizar seus aspectos negativos (Lima et al., 2005).

Hassel et al. (2009) estudaram os diferentes métodos de associação de biorreatores anaeróbios e aeróbios, e constataram que é vantajosa essa combinação devido a requisitos 
mínimos de espaço, baixo custo de capital e eficiências satisfatórias de remoção de DQO (acima de 83\%).

Os processos biológicos aeróbios são comumente usados no tratamento de águas residuárias orgânicas para atingir um alto grau de eficiência de tratamento. No caso do tratamento anaeróbio, registraram-se progressos consideráveis no domínio da biotecnologia anaeróbia de tratamento de resíduos com base no conceito de recuperação e utilização de recursos enquanto ainda alcança o objetivo de controle da poluição (Hassel et al., 2009).

Gonçalves et al. (1997) estudaram um sistema composto por reator UASB (46 L) seguido de filtro biológico aerado submerso $(6,3 \mathrm{~L})$, em escala piloto, utilizados no tratamento do esgoto sanitário coletado a jusante do pré-tratamento da ETE de Camburi em Vitória. O meio granular do filtro biológico aerado submerso era flutuante e totalmente submerso, sendo composto por esferas de poliestireno do tipo S5 com diâmetro de $3 \mathrm{~mm}$. O ar era injetado na base do filtro biológico aerado submerso com fluxo ascendente, em sentido cocorrente com o esgoto. O objetivo principal foi a remoção de matéria orgânica. Esse sistema operou durante 322 dias, no qual as cargas, hidráulica e orgânica, aplicadas ao sistema foram paulatinamente incrementadas. As condições operacionais adotadas para os reatores UASB e o filtro biológico aerado submerso (BF) são apresentadas na Tabela 3.4.

Tabela 3.4: Condições operacionais adotadas para os reatores UASB e o BF

\begin{tabular}{cccccc}
\hline Etapas & \multicolumn{2}{c}{ TDH (h) } & Q & Carga hidráulica UASB e BF & Duração \\
\cline { 2 - 4 } & UASB & BF & $(\mathbf{L} / \mathbf{h})$ & $\left(\mathbf{m}^{\mathbf{3}} / \mathbf{m}^{\mathbf{2}} \mathbf{. h}\right)$ & (d) \\
\hline $\mathbf{1}$ & 16 & 0,46 & 2,8 & 0,36 & 64 \\
\hline $\mathbf{2}$ & 10 & 0,28 & 4,6 & 0,58 & 74 \\
\hline $\mathbf{3}$ & 8 & 0,23 & 5,7 & 0,73 & 30 \\
\hline $\mathbf{4}$ & 6 & 0,17 & 7,6 & 0,97 & 33 \\
\hline $\mathbf{5}$ & 4 & 0,11 & 11,4 & 1,45 & 45
\end{tabular}

Fonte: Gonçalves et al. (1997).

As eficiências médias de remoção de SS, DBO e DQO do conjunto foram respectivamente $94 \%, 96 \%$ e $91 \%$, resultando em efluente final com as seguintes características: $10 \mathrm{mg} / \mathrm{L}$ 
de SS, DBO de $9 \mathrm{mg} / \mathrm{L}$ e DQO de $38 \mathrm{mg} / \mathrm{L}$. Esses resultados demonstram que os filtros aerados podem ser considerados uma alternativa viável para o pós-tratamento de efluentes de reatores UASB tratando esgotos domésticos.

Del Pozo e Diez (2003) avaliaram a combinação de dois biorreatores de filme fixo (FFB) anaeróbio-aeróbio, respectivamente, em escala piloto, associados em série com recirculação do efluente, para tratamento de águas residuárias de um abatedouro de aves. Este efluente apresentou um elevado teor de óleos e graxas (O \& G) causando problemas de flotação em sistemas de biomassa em suspensão, optou-se pela escolha do FFB para este sistema. Longos tubos de PVC corrugados foram colocados verticalmente como meios de apoio para evitar entupimento, enquanto a estrutura áspera dos tubos favoreceu o aumento da sua superfície específica, além de proteger a biomassa aderida das forças de cisalhamento.

Estes FFBs foram operados com fluxo descendente, recirculando o efluente do aeróbio para o anaeróbio. A remoção de matéria orgânica ocorreu principalmente nos biorreatores de filme fixo anaeróbio, e este efeito foi acentuado quando a proporção de recirculação aumentou de 1 a 6 . O aumento de recirculação era favorável para o processo de desnitrificação. Índices de recirculação superiores a 6 causaram aumento de amônia livre no biorreator de filme fixo aeróbico que inibiu o processo de nitrificação. Os resultados apresentaram eficiência de $92 \%$ de remoção de DQO, obtendo cargas orgânicas de 0,39 $\mathrm{kgDQO} / \mathrm{m}^{3}$.d, e NTK com eficiência de $95 \%$ de remoção com taxa de carga de nitrogênio de $0,064 \mathrm{~kg} \mathrm{NTK} / \mathrm{m}^{3} . \mathrm{d}$.

Foco (2010) estudou o desempenho de um sistema combinado anaeróbio-aeróbio, em escala de bancada, tratando esgoto sanitário da Unicamp, constituído por filtro anaeróbio (FA) seguido de biofiltro aerado submerso (BAS), empregados para a conversão de matéria orgânica e nitrogênio amoniacal, sem a recirculação de biomassa das unidades.

O sistema combinado operado por Foco (2010) foi dividido em três etapas, cada uma subdividida em duas fases. O FA e o BAS receberam o mesmo meio suporte, eletrodutos corrugados, e operaram com volume útil de 32,6 e 17,6 L, respectivamente. A primeira etapa referiu-se ao início da operação do sistema combinado, subdividida em dois regimes hidráulicos, TDH total de 23,2 e 20,9 h, cujo objetivo era monitorar o comportamento 
global do sistema durante o estabelecimento do equilíbrio dinâmico, principalmente quanto a formação da biomassa ativa no FA. O equilíbrio dinâmico ocorreu por volta do $24^{\circ}$ dia, quando o sistema é avaliado globalmente, porém só atingiu maior estabilidade por volta do $38^{\circ}$ dia, quando ocorreu o equilíbrio dinâmico no processo anaeróbio.

A primeira etapa, do sistema combinado operado por Foco (2010), durou 78 dias. A segunda etapa, operou com TDH total de 18,6 e 13,9, teve duração de 210 dias, cujo o objetivo foi avaliar a capacidade do sistema em degradar matéria orgânica e converter nitrogênio amoniacal em nitrito e nitrato. Inicialmente obteve-se baixa eficiência de conversão de nitrogênio amoniacal, provavelmente devido à assimilação de nitrogênio pela biomassa. Após aplicar uma maior taxa de aplicação hidráulica, que pode ter provocado o cisalhamento do biofilme favorecendo o transporte de massa, e consequentemente uma maior produção de biomassa decorrente das maiores taxas de carregamento orgânico (TCO) aplicadas. Porém, o efluente final atendeu a legislação de lançamento de efluente. A terceira e última etapa operou durante 116 dias com TDH de 18,6 e vazão de 2,7 L/h, avaliou a capacidade do sistema de promover a desnitrificação e consequente remoção de nitrogênio, operando sem e com a recirculação do efluente tratado. Desta maneira avaliou a desnitrificação pelo encaminhamento do efluente formado no BAS para o FA, onde, em ambiente redutor, os doadores de elétrons utilizados foram os compostos orgânicos de rápida biodegradação presentes no esgoto bruto e os ácidos orgânicos formados no processo anaeróbio. A recirculação do efluente não interferiu na conversão de matéria orgânica, indicando que a configuração e a operação proposta eram adequadas para atender as expectativas sobre sua robustez e possibilidade de reduzir a concentração de carbono orgânico e compostos de nitrogênio.

Foco (2010) obteve melhor desempenho operacional com TDH global de 18,6 h (12,1 h no FA e 6,5 h no BAS), que apresentou redução das concentrações de 93\% de DQO, 99\% de DBO e 98\% SST, e com concentrações médias efluentes de $48 \mathrm{mg} / 1$ de DQO, $5 \mathrm{mg} / \mathrm{l}$ de DBO e $3 \mathrm{mg} / 1$ de SST ( $2^{\circ}$ etapa), não havendo diferenças significativas ( $\left.p>0,05\right)$ com o desempenho da $3^{\circ}$ etapa.

Já Araújo e Freitas (2014) desenvolveram um sistema combinado, em escala de bancada, composto por reator anaeróbio de manta de lodo (UASB) e biofiltro aerado submerso 
(BFAS), cujo meio suporte utilizado foi espuma de poliuretano envolto por anel de polipropileno perfurado. O objetivo deste trabalho foi avaliar a remoção da matéria orgânica e a ocorrência da nitrificação, utilizando água residuária sintética como afluente. Este sistema experimental foi construído em policloreto de polivinila (PVC) com uma altura de 1,82 m, 0,15 m de diâmetro, volume do reator UASB de $18 \mathrm{~L}$, do BFAS de 14 L, TDH de 7,9 horas e 6,4 horas, respectivamente, e vazão de alimentação de 52,56 L/dia. Teve duração de 63 dias, dividido em duas etapas, na primeira o sistema operou apenas o reator UASB e não obteve bom desempenho, com eficiência de remoção média de $37 \%$ de DQO e concentração efluente de $318 \mathrm{mg} / 1$, e $81 \%$ de remoção de SST e concentração efluente de $44 \mathrm{mg} / \mathrm{l}$.

Na segunda etapa, Araújo e Freitas (2014) iniciaram a operação do sistema combinado, e obtiveram eficiência global média de acima de $70 \%$ na remoção de DQO com concentração de $115 \mathrm{mg} / \mathrm{l}$, e 47\% de remoção de SST com concentração de $83 \mathrm{mg} / \mathrm{l}$. O sistema combinado favoreceu a ocorrência da nitrificação, oxidando $25 \%$ do nitrogênio amoniacal presente no efluente. O resultado com favorecimento do processo de nitrificação foi atribuído ao meio suporte utilizado, devido a boa aderência da biomassa.

Com o objetivo de avaliar o desempenho de diferentes tipos de meio suporte, com diferentes alturas, utilizados em filtro anaeróbio Ávila (2005) monitorou, através de análises físico-químicas, durante seis meses um sistema composto por tanque séptico seguido de filtro anaeróbio com três tipos de recheio (anéis de plástico, cubos de espuma e brita $\mathrm{n}^{\mathrm{o}}$ 4). As alturas dos filtros anaeróbios variaram de 0,69 a 1,20 m. Com resultados obtidos foi possível concluir que a utilização de filtros com altura útil a partir de 0,69 $\mathrm{m}$ é viável e capaz de apresentar desempenho satisfatório semelhante aos dos filtros com altura de 1,20 m. Os três tipos de meio suporte atenderam plenamente as exigências da legislação vigente e apresentaram eficiências da ordem de $69 \%, 73 \%$ e $68 \%$ na remoção de DQO, $68 \%, 67 \%$ e $62 \%$ na remoção de DBO, e $90 \%, 93 \%$ e $90 \%$ na remoção de SST nos filtros de anéis de plástico, brita $n^{\circ} .4$ e cubos de espuma respectivamente. Ávila (2005) obteve melhores resultados com a brita $\mathrm{n}^{\mathrm{o}} 4$ como meio de suporte. Porém, demonstrou viabilidade no uso de espuma como meio suporte, com desempenho semelhante aos anéis de plástico. 
Goffi (2013) também avaliou o desempenho de um sistema anaeróbio-aeróbio de leito fixo sem e com recirculação da fase liquida, no tratamento de esgoto sanitário da Universidade Tecnológica Federal do Paraná, campus Campo Mourão, proveniente dos banheiros, além de determinados resíduos de laboratórios. O sistema anaeróbio-aeróbio utilizou dois tipos de meio suporte, espumas de poliuretano e argila expandida, desenvolvido em escala de bancada, com volume de 4,75 L, sendo 2,85 L correspondentes à zona anaeróbia e 1,9 L à zona aeróbia. O sistema foi operado com vazão afluente de $0,6 \mathrm{~L} / \mathrm{h}$ e TDH de 8 h, mantido a temperatura ambiente. Além das análises físico-químicas, o sistema foi avaliado com exames microscópicos, para avaliar a microbiota presente no reator. Entre as bactérias, foram observadas: cocos, vibrios, bacilos e filamentos. Na etapa de operação sem recirculação, o sistema apresentou elevadas eficiências de remoção de matéria orgânica em termos de DQO, com 86\%, e 63\% de remoção de sólidos. Mesmo submetido a variações de carga orgânica o sistema combinado manteve-se estável. Na etapa de operação com recirculação do efluente tratado, o desempenho melhorou, chegando a 99\% de remoção em relação matéria orgânica e a remoção de nitrogênio total foi de $71 \%$ para razão de recirculação de 0,5. Assim, o reator avaliado apresentou estabilidade operacional, alta remoção de matéria orgânica e nitrogênio.

Já Barbosa (2006) avaliou um sistema combinado, em escala de bancada, constituído por um tanque séptico (TS - 27 litros) seguido de biofiltro aerado submerso (BAS - 6,3 litros), na remoção de matéria orgânica residual e nitrificação, tratando água residuária sintética. $\mathrm{O}$ sistema foi operado com variação do TDH. Na primeira etapa o TS operou com TDH variando de 12 a 24 horas, enquanto o BAS operou com TDH de 4 horas, taxa de aplicação superficial de $5,01 \mathrm{~m}^{3} / \mathrm{m}^{2}$.dia e carga orgânica volumétrica (COV) média de 1,05 $\mathrm{kgDQO} / \mathrm{m}^{3}$.dia. Na segunda fase a unidade TS foi operada com TDH de 15 horas e a unidade BAS com o TDH de 2 horas, taxa de aplicação superficial de $10,02 \mathrm{~m}^{3} / \mathrm{m}^{2}$.dia, e COV média de $1,97 \mathrm{kgDQO} / \mathrm{m}^{3}$.dia. A remoção de nitrogênio amoniacal no BAS na primeira etapa foi de $84 \%$, e de $36 \%$ para a segunda etapa. O sistema combinado apresentou melhor desempenho na primeira etapa obtendo eficiências médias de remoção de $90 \%$ de DQO, 95\% de carbono orgânico total (COT) e 91\% de DBO.

O sistema de tratamento, do tipo anaeróbio, operado por Achaval (2014) que foi concebido em escala piloto, dividido em três câmaras, a primeira composta por um Tanque Imhoff 
modificado com decantador laminar, a segunda por um filtro anaeróbio, e a terceira por um filtro anaeróbio com um Decantador Laminar Secundário, utilizando como meio suporte dos filtros anaeróbios fragmentos de eletrodutos (conduítes), fabricado em fibra de vidro e instalado em uma casa térrea no Distrito Federal (DF) que possuía, em média, cinco residentes. O objetivo almejado por Achaval (2014) foi o de produzir um protótipo que fosse eficiente, a ponto de chegar à qualidade compatível afluentes de tratamento de "nível secundário". O sistema foi operado sob condições reais, tratando esgoto de característica unifamiliar, instalado no local de produção e origem do esgoto.

O sistema de tratamento operado por Achaval (2014) obteve, na fase estabilizada, eficiência de remoção média de $84,68 \%$ e concentração de 112,38 mg/L de DBO5, 81,15\% e concentração média de 265,2 mg/L de DQO, 87,14\% de 34,9 mg/L de SST, 25,17\% e concentração média de $10,62 \mathrm{mg} / \mathrm{L}$ de fósforo total. 


\section{4 - METODOLOGIA}

A pesquisa foi realizada com a finalidade de avaliar o desempenho do sistema de tratamento composto pela combinação de filtro anaeróbio seguido pelo biofiltro aeróbio submerso, usando meio suporte composto por espuma de poliuretano, na redução da produção de lodo e no tratamento de água residuária sintética cujas características simularam esgotos domésticos provenientes de unidades residenciais unifamiliares. $\mathrm{O}$ sistema foi estudado em escala de bancada, com a reprodução, do esgoto doméstico, feita em laboratório. Para atingir o objetivo desta pesquisa, seguiram-se as etapas apresentadas na Figura 4.1.

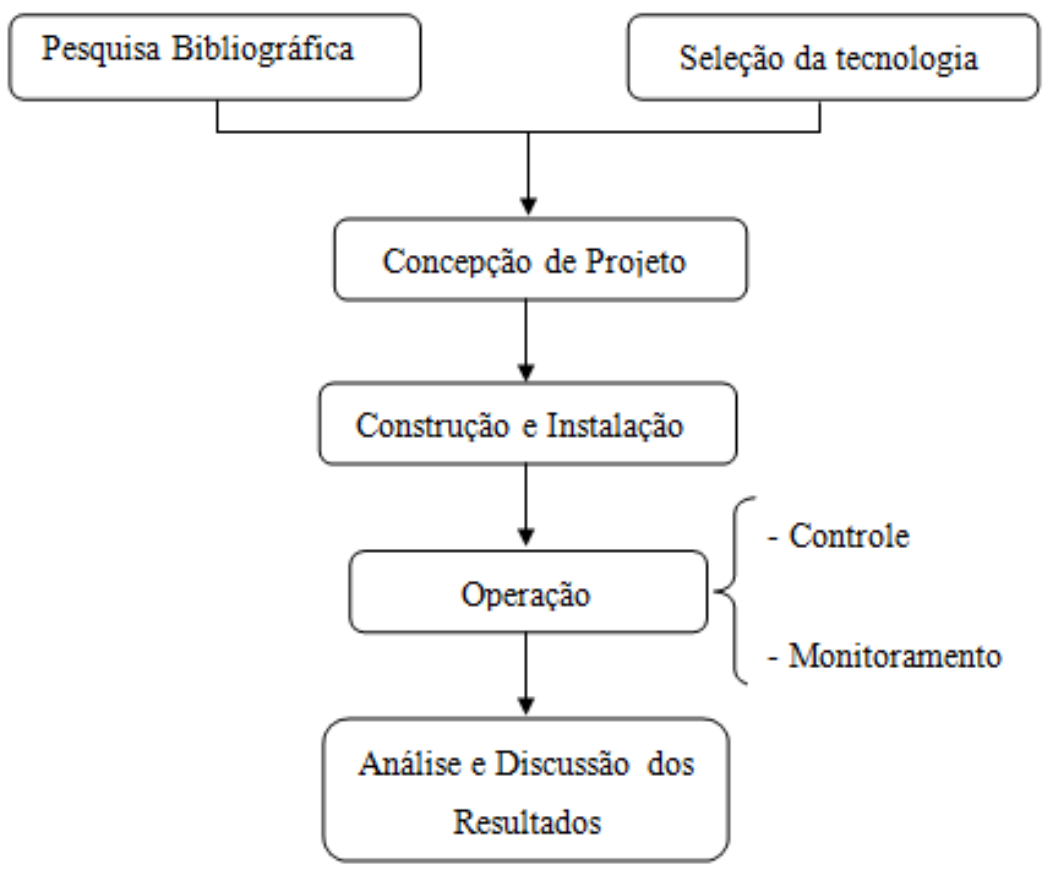

Figura 4.1: Diagrama simplificado da metodologia

O sistema foi projetado em escala de bancada, de modo a ser instalado e operado no Laboratório de Saneamento Ambiental (LSA) do Programa de Tecnologia Ambiental e Recursos Hídricos (PTARH) da Universidade de Brasília (UnB). A água residuária sintética foi produzida em laboratório com as características compatíveis a dos esgotos de uma unidade geradora unifamiliar e foi utilizada como afluente do sistema combinado de tratamento de esgoto doméstico em escala de bancada. 


\section{1 - CONCEPÇÃO DO PROJETO DE TRATAMENTO DE ESGOTOS COMPOSTO PELOS PROCESSOS FILTRO ANAERÓBIO SEGUIDO DE BIOFILTRO AERADO SUBMERSO}

Nesta etapa, foi projetado o modelo de sistema de tratamento combinado anaeróbioaeróbio, em escala de bancada, com as unidades propostas de Filtro Anaeróbio (FAn), Biofiltro Aerado Submerso (BAS) e dois decantadores, para tratar água residuária sintética que reproduzia as características de um esgoto doméstico de uma unidade unifamiliar. A vazão média de projeto adotada foi de $40 \mathrm{~L} / \mathrm{d}$ ou $0,04 \mathrm{~m}^{3} / \mathrm{d}$.

Buscou-se o desenvolvimento de um modelo de sistema de tratamento biológico em escala de bancada que fosse capaz de reproduzir em laboratório o tratamento do efluente líquido gerado por uma unidade unifamiliar com baixa produção de lodo, associando os conceitos de filtro anaeróbio e de filtro aerado de forma eficiente. De modo que, em posse dos resultados encontrados, fosse possível conceber um protótipo em escala real para instalação em uma residência.

Após realizar-se a pesquisa bibliográfica e definir o tipo de sistema combinado a ser concebido, foi realizado o delineamento do sistema, para então chegar-se à concepção de um modelo de sistema combinado constituído por um Filtro Anaeróbio, em estrutura de PVC, com 0,3 m de diâmetro e 0,5 $\mathrm{m}$ de altura total, sendo $0,09 \mathrm{~m}$ de borda livre, 0,34 m de leito filtrante e $0,07 \mathrm{~mm}$ de fundo falso, com volume total de aproximadamente $31 \mathrm{~L}$. O Filtro Anaeróbio procedeu um Biofiltro Aerado Submerso, em estrutura de PVC, com 0,2 $\mathrm{m}$ de diâmetro e $0,5 \mathrm{~m}$ de altura total, sendo $0,11 \mathrm{~m}$ de borda livre, $0,31 \mathrm{~m}$ de leito filtrante e $0,08 \mathrm{~m}$ de fundo falso, com volume total de aproximadamente $12 \mathrm{~L}$.

\subsection{1 - Dimensionamento}

Por se tratar de um projeto de bancada, o dimensionamento foi baseado em dados empíricos obtidos na literatura, uma vez que não existem parâmetros de projeto previamente estabelecidos para esse sistema. Neste caso, não se aplicam os parâmetros de projeto da NBR - 13969/97. 


\subsubsection{1 - Filtro Anaeróbio (FAn)}

O Tempo de Detenção Hidráulica (TDH) do filtro anaeróbio foi calculado aplicando a Equação (4.1) em função da vazão e volume do filtro.

$$
V o l_{\text {fan }}=Q_{\text {média }} \times T D H
$$

$\mathrm{Na}$ Equação (4.1) $\mathrm{V}_{\text {fan }}$ é o volume útil do filtro anaeróbio, expresso em m³, $\mathrm{Q}_{\text {média }}$ é a vazão média, expressa em m³/d, e TDH é o tempo de detenção hidráulica, expresso em d.

Segundo Gonçalves et al, (2001), tem-se observado que os FAn quando operados com TDH na faixa de 4 a 10h são capazes de produzir efluentes que atendem aos padrões de lançamento estabelecidos pelos órgãos ambientais, em termos de concentração de DBO. Entretanto, como a abordagem desta pesquisa foi com um sistema de bancada, usou-se um TDH de 12 horas, tomando como base Foco (2010) que utilizou o mesmo TDH e obteve resultados satisfatórios ao tratar esgoto sanitário.

A altura total do filtro anaeróbio foi calculada pela Equação (4.2), respeitando o volume em função da vazão média e do TDH.

$$
H_{\text {total }}=H_{1}+H_{2}+H_{3}
$$

$\mathrm{Na}$ Equação (4.2) a $\mathrm{H}_{\text {total }}$ é altura total do filtro, expressa em $\mathrm{m}, \mathrm{H}_{1}$ é altura do meio

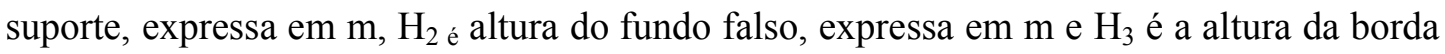
livre, expressa em m.

A área do filtro anaeróbio foi calculada pela Equação (4.3).

$$
A_{\text {filtro }}=\operatorname{Vol}_{\text {fan }} / H_{\text {total }}
$$


$\mathrm{Na}$ Equação (4.3) $\mathrm{A}_{\text {filtro }}$ é a área do filtro, expressa em $\mathrm{m}^{2}, \mathrm{~V}_{\text {fan }}$ é o volume do filtro anaeróbio, expresso em $\mathrm{m}^{3}$, e $\mathrm{H}_{\text {total }}$ é a altura total do filtro anaeróbio, expressa em $\mathrm{m}$.

O volume do meio suporte foi calculado pela Equação (4.4).

$$
\text { Vol }_{\text {meio sup. }}=A_{\text {filtro }} / H_{1}
$$

Equação (4.4)

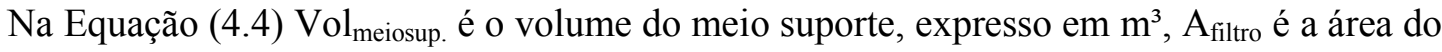
filtro anaeróbio, expressa em $\mathrm{m}^{2}$, e $\mathrm{H}_{1}$. é a altura do meio suporte, expressa em $\mathrm{m}$.

A Taxa de Aplicação Superficial foi calculada pela Equação (4.5).

$$
T A S=Q / A_{\text {filtro }}
$$

Equação (4.5)

Na Equação (4.5) TAS é a Taxa de aplicação superficial, expressa em $\mathrm{m}^{3} / \mathrm{m}^{2}$.d, Q é a vazão média ou máxima horária, expressa $\mathrm{em}^{3} / \mathrm{d}$, e $\mathrm{A}_{\text {filtro }}$ é a Área do filtro anaeróbio, expressa em $\mathrm{m}^{2}$.

A Carga Orgânica Volumétrica foi calculada pela Equação (4.6).

$$
C O V=\frac{Q_{\text {média }} \times S a}{V o l}
$$

$\mathrm{Na}$ Equação (4.6) COV é a carga orgânica volumétrica, expressa em $\mathrm{kgDBO} / \mathrm{m}^{3}$.d, $\mathrm{Q}_{\text {média }}$ é a vazão, expressa em $\mathrm{m}^{3} / \mathrm{d}$, Sa é a concentração de $\mathrm{DBO}$ de esgoto afluente ao filtro anaeróbio, expressa em $\mathrm{kgDBO} / \mathrm{m}^{3}$, e Vol é o volume total do filtro anaeróbio ou volume ocupado pelo meio suporte, expresso em $\mathrm{m}^{3}$. 
Assim, para a vazão média adotada de $0,04 \mathrm{~m}^{3} / \mathrm{d}$, chegou-se ao volume útil do FAn de 0,0197 $\mathrm{m}^{3}$, para um tempo de detenção hidráulica médio de 12 horas. A área do filtro obtida foi de $0,039 \mathrm{~m}^{2}$ e volume do meio suporte de $0,013 \mathrm{~m}^{3}$. As dimensões do filtro anaeróbio concebido são ilustradas na Figura 4.2.

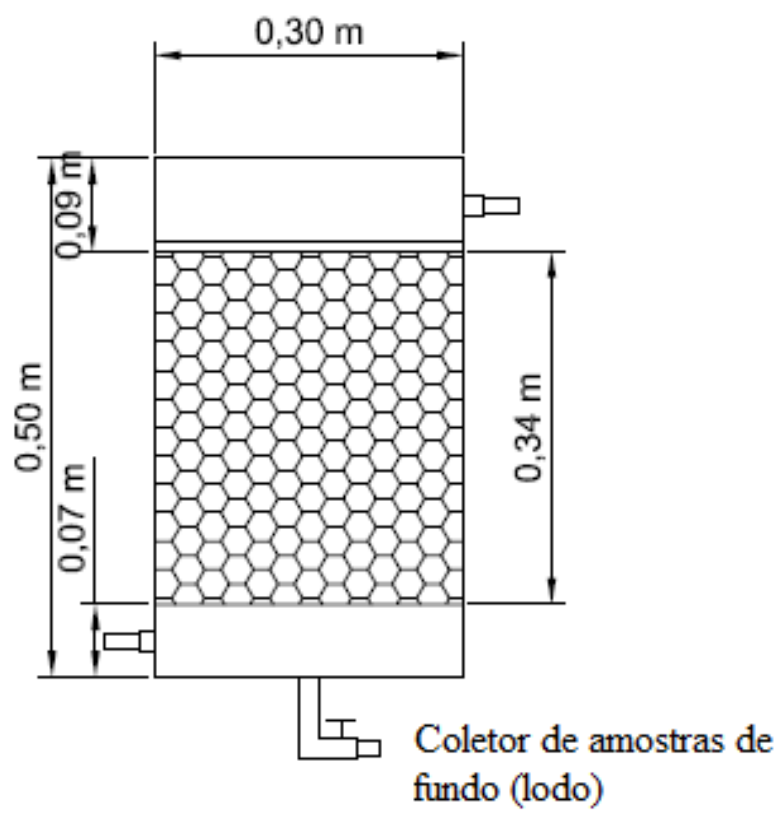

Figura 4.2: Dimensões do Filtro Anaeróbio (FAn). Unidade em metros, sem escala.

\subsubsection{2 - Biofiltro Aeróbio Submerso}

A unidade aeróbia foi projetada adotando dados empíricos obtidos em outros trabalhos, para operar como pós-tratamento do efluente da unidade FAn, com o objetivo de realizar o polimento do efluente do FAn.

O projeto do BAS foi baseado nas experiências de Barbosa (2006), Foco (2010), Gonçalves (2001) e Martins (2010), que projetaram uma unidade de BAS com parâmetros e configurações diferentes dos que foram indicados na NBR - 13696/97. Os parâmetros utilizados para o dimensionamento deste reator foram a COV e a altura do reator. Cada um dos autores mencionados adotou COV distinta e obtiveram reatores com diferentes capacidades, volumes e alturas de recheios. Contudo as configurações dos reatores foram 
as mesmas, operaram com fluxo ascendente, com somente uma única coluna de material suporte, diferentemente das recomendações da NBR-13696/97.

Por se tratar de um experimento em escala de bancada, e os parâmetros estabelecidos referirem-se à escala real, optou-se por adotar uma altura total de $0,5 \mathrm{~m}$, sendo $0,31 \mathrm{~m}$ de profundidade do leito filtrante, como se pode observar na Figura 4.3.

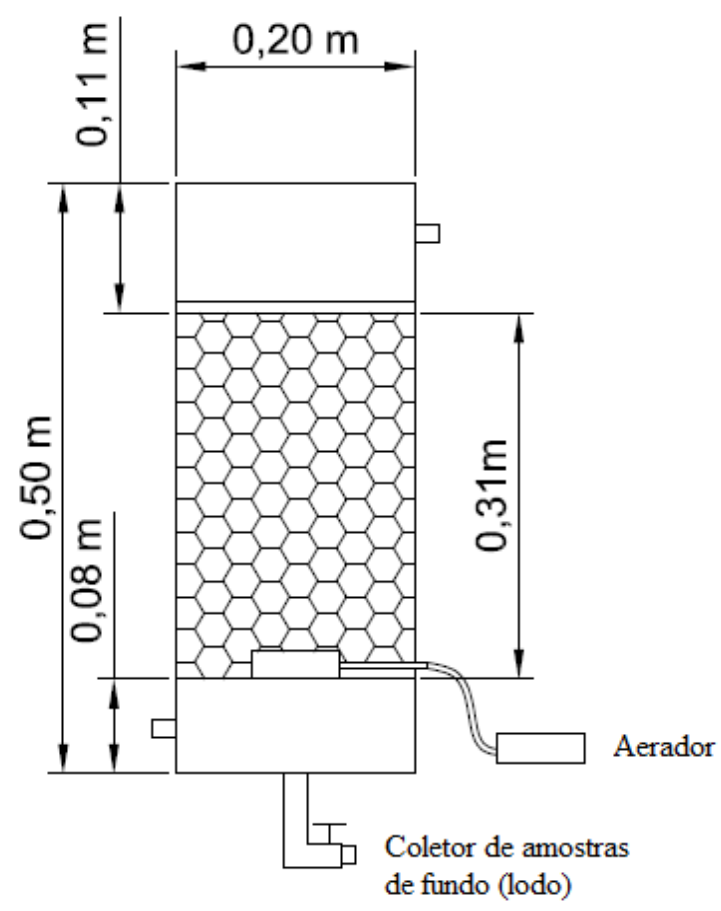

Figura 4.3: Biofiltro Aerado Submerso (BAS). Unidade em metros, sem escala.

Como o BAS foi projetado com uma altura menor que a recomendada pela literatura, foram adotados valores menores de COV e taxa de aplicação superficial para a operação da unidade.

O valor obtido após os devidos cálculos foi de $\mathrm{COV}=1,9 \mathrm{kgDQO} / \mathrm{m}^{3} . \mathrm{d}$, considerando uma $\mathrm{DQO}_{\text {média }}$ de $240 \mathrm{mg} / \mathrm{L}\left(0,24 \mathrm{~kg} / \mathrm{m}^{3}\right)$, estimando em $70 \%$ a eficiência de remoção de DQO do FAn. 
O diâmetro adotado foi de $0,2 \mathrm{~m}$, e com a altura de 0,5 $\mathrm{m}$ do BAS, obteve-se um volume útil de aproximadamente $9 \mathrm{~L}$, a vazão média adotada foi de $0,04 \mathrm{~m}^{3} / \mathrm{d}$, o TDH foi de 4,8 horas. Outro parâmetro importante foi a taxa de aplicação superficial que foi de $3 \mathrm{~m}^{3} / \mathrm{m}^{2}$.d.

\subsubsection{3 - Decantadores Secundários}

Os decantadores secundários foram projetados com objetivo de quantificar os sólidos provenientes do FAn e do BAS. O projeto teve como base o modelo utilizado por Foco (2010), reaproveitando garrafões plásticos de 20 litros, material transparente com inclinação na saída.

A distribuição de entrada do efluente foi realizada pelo fundo da unidade de decantação, e a saída pela superfície, através de uma calha perfurada, com altura de 0,15 m, 0,28 $\mathrm{m}$ de diâmetro, como é mostrado no desenho esquemático apresentado na Figura 4.4.

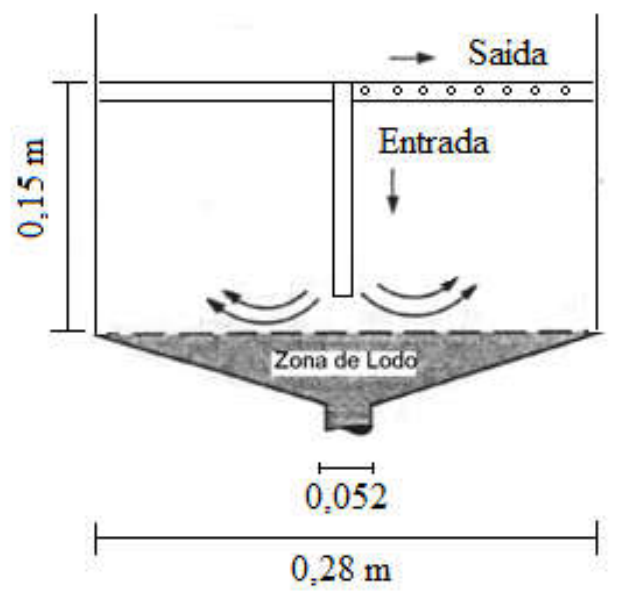

Figura 4.4: Desenho esquemático do decantador.

4.1.1.4 - Sistema combinado por Filtro Anaeróbio seguido de Biofiltro aerado submerso

Como mostra a Figura 4.5, o sistema de tratamento foi composto por um total de oito componentes, primeiramente o reservatório para armazenamento do afluente, do qual, com o auxílio de uma bomba submersa (Sarlobetter Sb 2000), era distribuído a água residuária sintética para um reservatório de nível, onde era feito o controle da vazão que era 
encaminhada para o um filtro anaeróbio de fluxo ascendente, seguido de um decantador (Dec 1), o biofiltro aerado submerso (BAS) de fluxo ascendente, um decantador (Dec 2) e por fim o reservatório de armazenamento do efluente final, onde era feito o monitoramento da vazão do sistema.

Para o armazenamento da água residuária sintética eram utilizados dois reservatórios alternadamente, durante a semana era utilizado um reservatório com capacidade máxima de 60 litros, e, aos finais de semana era utilizado um reservatório com capacidade máxima de 200 litros. Esse afluente era distribuído por ação da gravidade a partir da caixa de nível, e sua vazão era controlada por um registro do tipo agulha, que ficava na saída da caixa.

O controle da vazão foi realizado pelo sistema corta-fluxo, realizado manualmente, onde o cálculo da vazão volumétrica dava-se pelo volume coletado, em proveta, na saída do sistema em determinado tempo, usualmente 10 minutos. A aferição da vazão era realizada duas vezes ao dia, no período da manhã e no final da tarde, ou sempre que houvesse necessidade. E quando a vazão estava inferior ou superior a vazão esperada, era realizado o ajuste da vazão pelo registro do tio agulha e novamente aferia-se a vazão, até atingir a vazão pretendida.

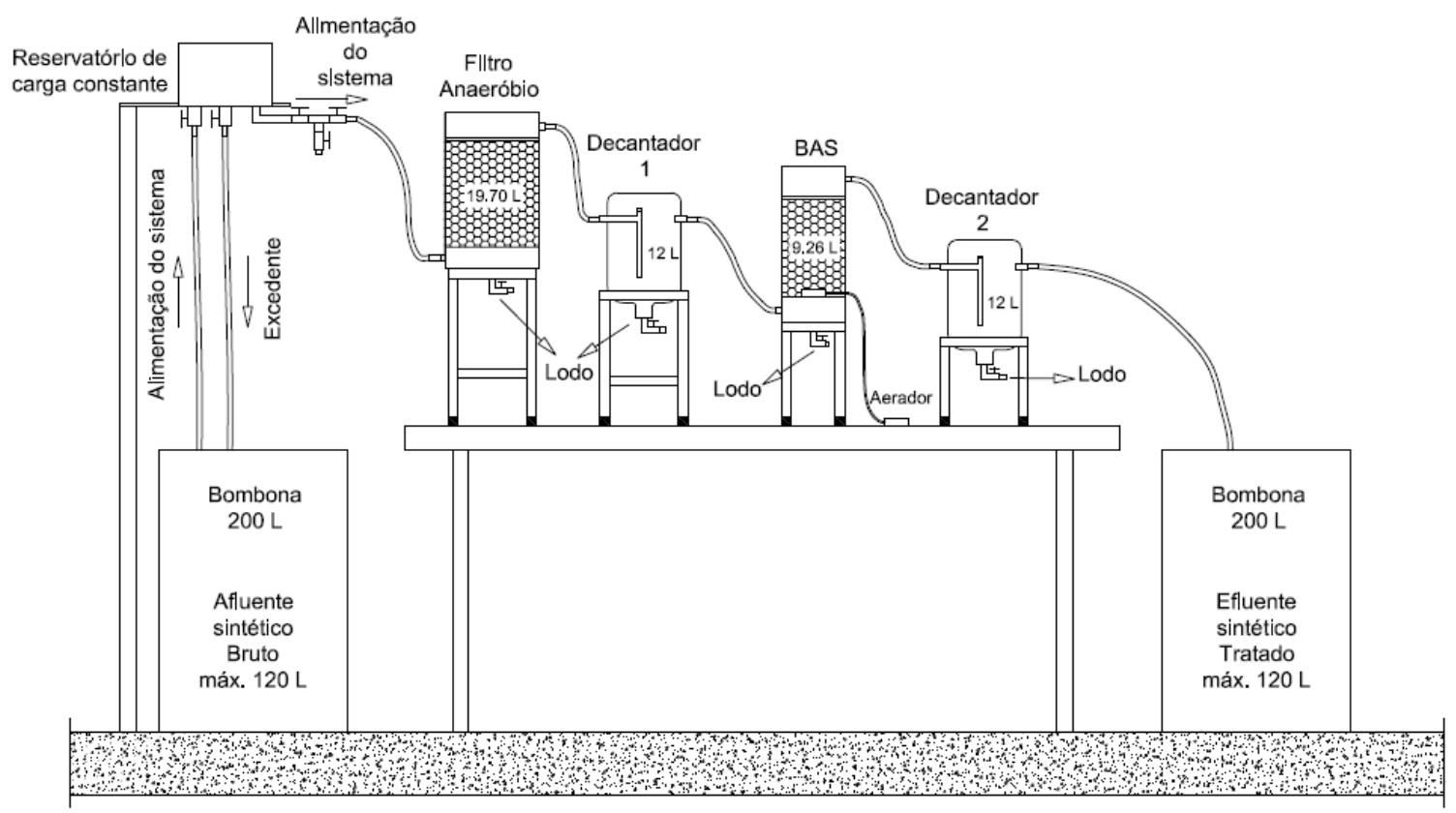

Figura 4.5: Sistema Combinado de Filtro anaeróbio (FAn) seguido do Biofiltro Aerado Submerso (BAS). 
Os decantadores, Dec 1 e Dec 2, que ficavam na saída dos filtros, tinham por finalidade servir como caixa de passagem, onde também se retiveram sólidos sedimentáveis (SSed) e realizaram-se coletas para medir a geração de lodo após a passagem do efluente pelos filtros.

\section{2 - CONSTRUÇÃO E INSTALAÇÃO DO MODELO DE ESCALA DE BANCADA DO SISTEMA DE TRATAMENTO DE ESGOTOS COMPOSTO PELOS PROCESSOS DE FILTRO ANAERÓbIO SEGUIDO DE FILTRO AERÓBIO}

\subsection{1 - Construção}

Foram definidos os seguintes itens, como definição do local para acomodação e instalação do sistema; formas e métodos de construção; especificação dos materiais e respectivas quantidades necessárias; orçamento do processo de fabricação; procedimento de fabricação; fabricação do modelo de escala de bancada propriamente dito e acabamentos.

A construção do sistema se deu pelas seguintes etapas: (1) Filtro Anaeróbio; (2) Biofiltro Aerado Submerso; (3) Decantadores; (4) Meio filtrante.

\subsubsection{1 - Filtro Anaeróbio (FAn)}

Para a confecção do Filtro Anaeróbio (FAn) foi utilizado tubo de PVC de esgoto (linha residencial soldável) com $300 \mathrm{~mm}$ de diâmetro e aproximadamente $500 \mathrm{~mm}$ de comprimento, fechado com um CAP de PVC de $300 \mathrm{~mm}$ de diâmetro em uma das extremidades, como mostrado na Figura 4.6, com volume aproximado de 31 litros. Os pontos de entrada e saída foram executados utilizando-se adaptadores com flanges da linha hidráulica roscável com diâmetro de 1/2”. Para a coleta de amostras, foi instalado um registro de esfera de $1 / 2$ " no fundo do filtro, também fixado com adaptadores com flange. Como base de sustentação do dispositivo foi idealizada uma estrutura de ferro (tipo tripé) combinada com tubos e conexões de PVC - linha hidráulica soldável - e abraçadeiras metálicas. No fundo falso foi utilizada uma placa de acrílico perfurada, para melhor distribuição do efluente. 


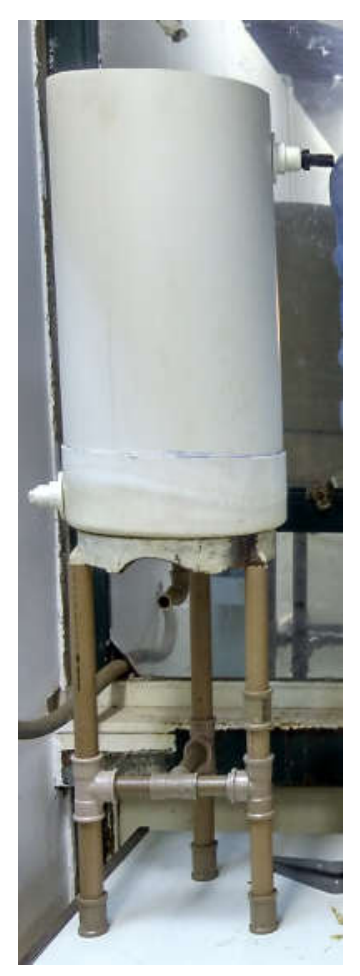

Figura 4.6: Filtro Anaeróbio (FAn) construído.

\subsubsection{2 - Biofiltro Aeróbio Submerso (BAS)}

Para a confecção do Biofiltro Aeróbio Submerso (BAS) foi utilizado tubo de PVC de esgoto (linha residencial soldável) com $200 \mathrm{~mm}$ de diâmetro e aproximadamente $500 \mathrm{~mm}$ de comprimento, fechado com um CAP de PVC de $200 \mathrm{~mm}$ de diâmetro em uma das extremidades, como mostrado na Figura 4.7 (a).

Assim como na unidade FAn, os pontos de entrada e saída foram confeccionados utilizando-se adaptadores com flanges da linha hidráulica roscável com 1/2". Para a coleta de amostras, foi instalado um registro de esfera de $1 / 2$ " de diâmetro no fundo do filtro, também fixado com adaptadores com flange. Como base de sustentação do dispositivo, foi idealizada uma estrutura de ferro (tipo tripé) combinada com tubos e conexões de PVC linha hidráulica soldável - e abraçadeiras metálicas. 


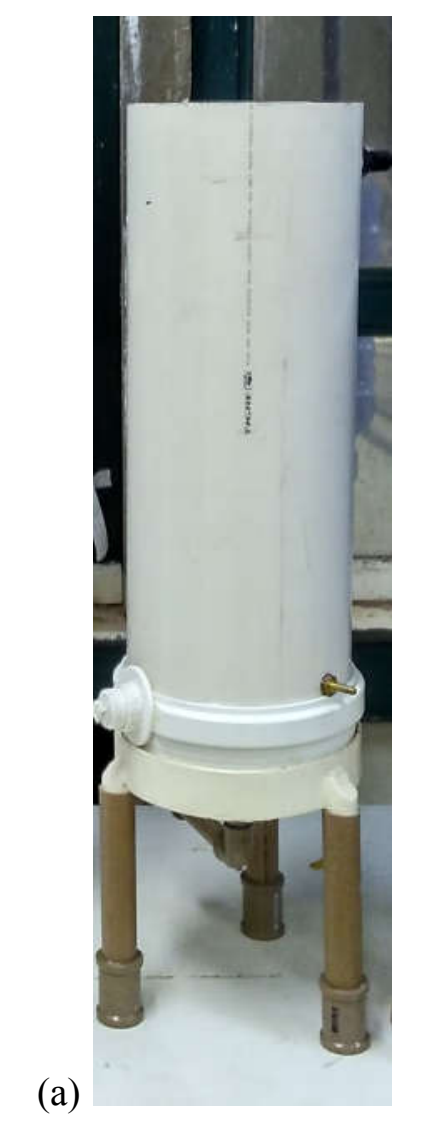

(b)

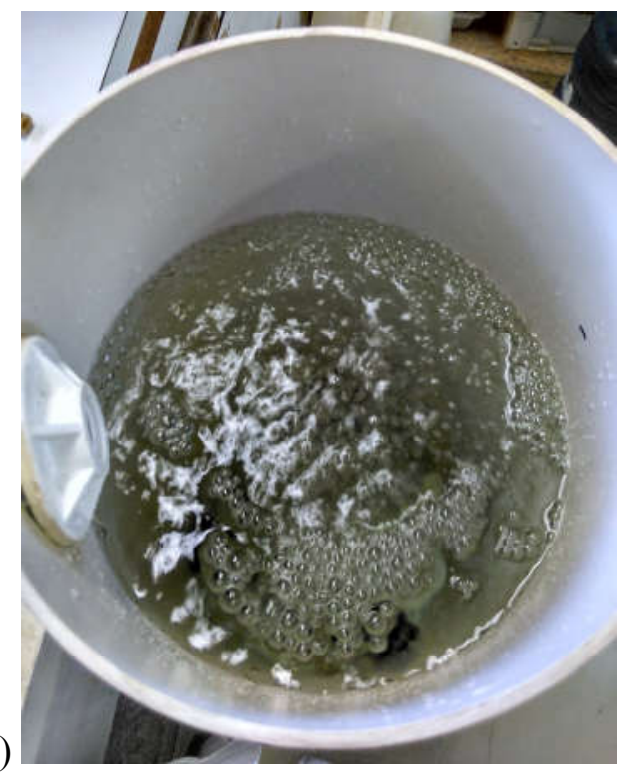

Figura 4.7: (a) Vista frontal do Biofiltro aeróbio submerso (BAS) e (b) Vista superior do BAS.

$\mathrm{Na}$ região do fundo falso, foram inseridas duas pedras porosas, conectadas a um compressor de ar (Big Air A420), utilizado em aquários, para fornecimento do oxigênio, como mostrado na Figura 4.7 (b).

\subsubsection{3 - Decantadores}

Os decantadores (Dec 1 e Dec 2) foram construídos a partir de galões plásticos comerciais utilizados para água mineral, com volume de 20 litros, como mostrado na Figura 4.8. Foram utilizados também tubos e conexões de PVC, um registro do tipo esfera, para coleta de lodo no fundo dos decantadores. Para a base também foi utilizada uma estrutura de ferro, tubos e conexões de PVC, e abraçadeiras metálicas. Os decantadores foram cobertos por sacos plásticos pretos, com intuito de evitar a entrada da luz solar. 


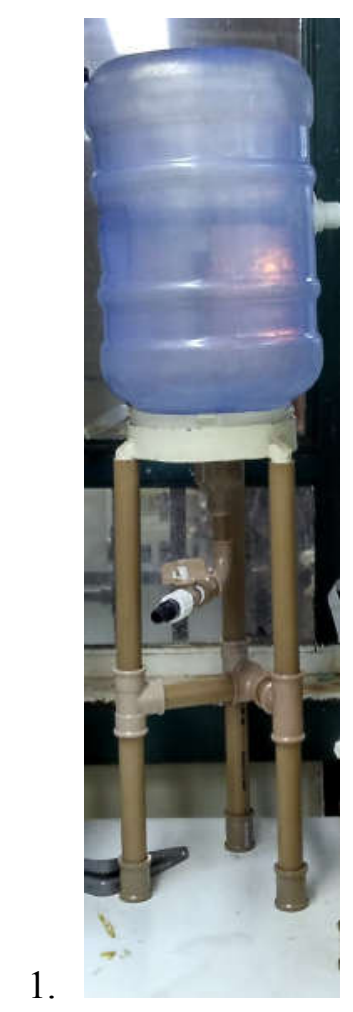

(b)
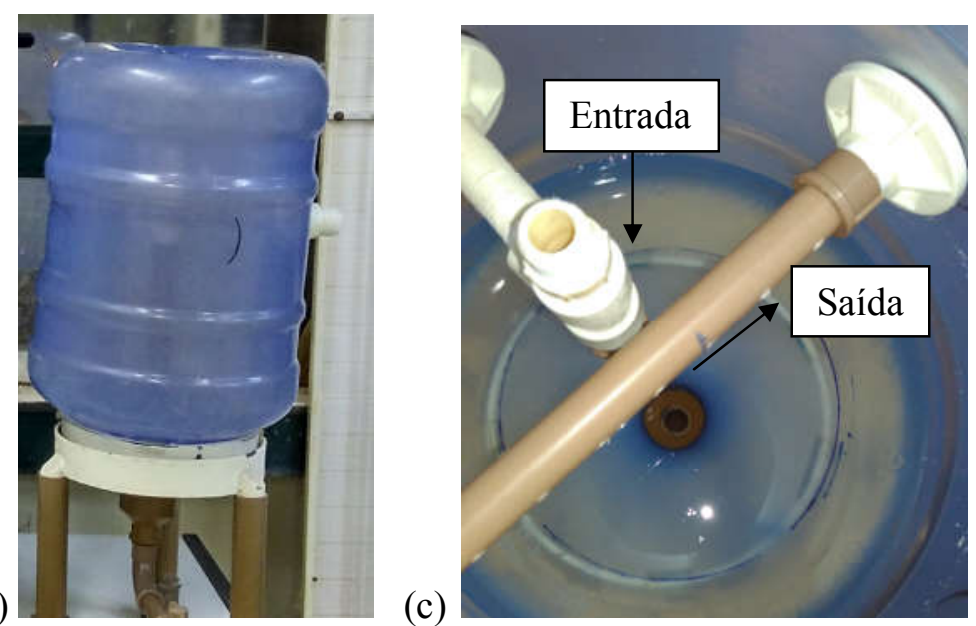

Figura 4.8: Decantadores (a) Dec 1; (b) Dec 2; (c) Vista superior do decantador

\subsubsection{4 - Meio Suporte}

Um critério de projeto muito importante também, considerado fundamental no dimensionamento do BAS, em escala de bancada, é a seleção do material de recheio. A relação do diâmetro do reator (DR) com o diâmetro da partícula do recheio (DP) influencia no "efeito parede", que, segundo Moore (2001), é minimizado quando o diâmetro do filtro é maior que 50 vezes o tamanho médio da partícula utilizada como recheio.

O meio suporte, mostrado na Figura 4.9, foi confeccionado em uma matriz de espuma de poliuretano D23 (1 cm de espessura, $3 \mathrm{~cm}$ de altura e $7 \mathrm{~cm}$ de comprimento) envolta por anéis de polipropileno (bob), com $3 \mathrm{~cm}$ de altura e $3 \mathrm{~cm}$ de diâmetro, permitindo que o efluente permeasse através do suporte.

Silva et al (2006), que utilizaram este mesmo tipo de material para meio suporte, levantaram as seguintes características deste recheio: densidade aparente de $23 \mathrm{~g} / \mathrm{L}$, porosidade $92 \%$ e área superficial de $43,8 \mathrm{~m}^{2} / \mathrm{g}$. 

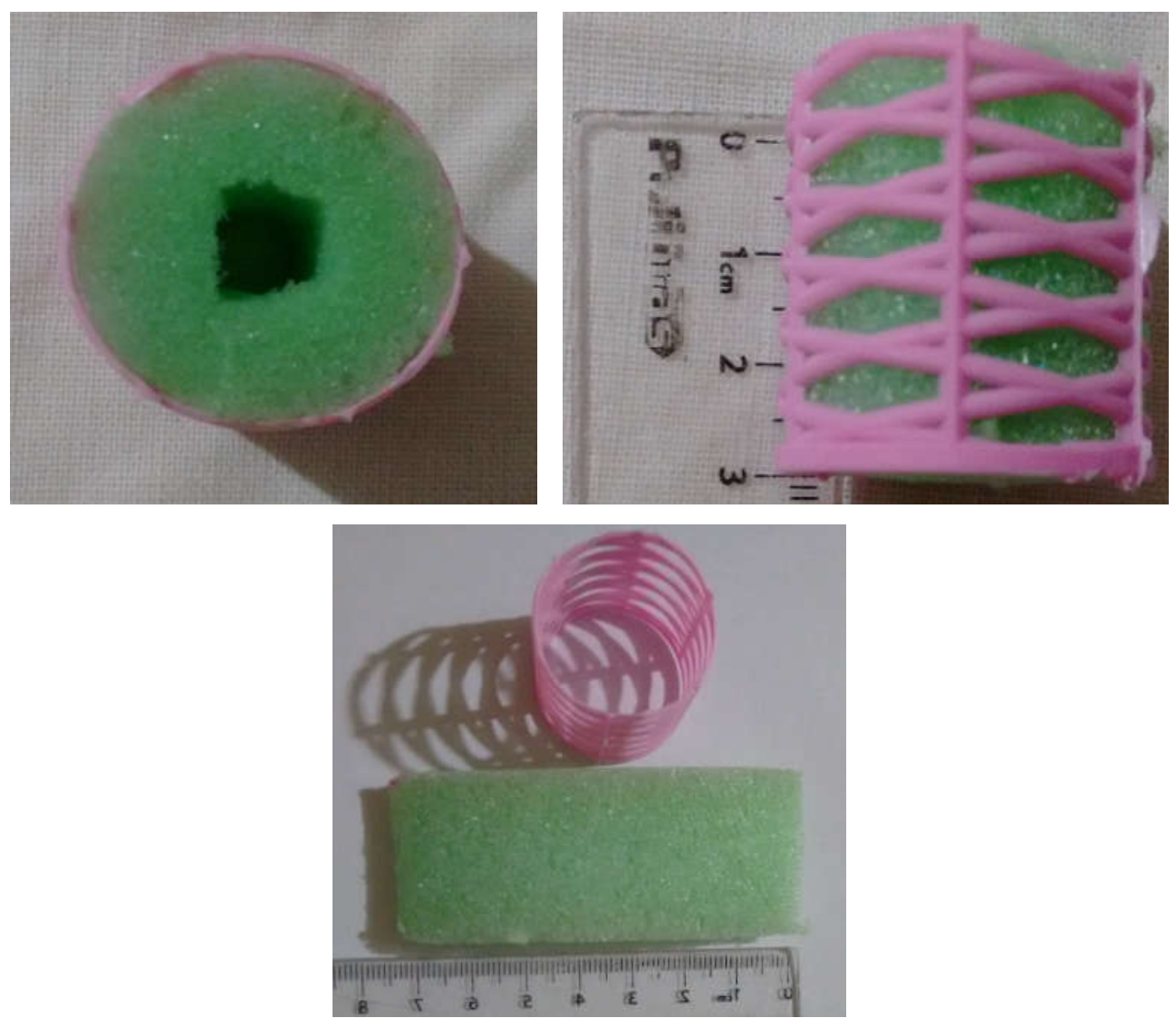

Figura 4.9: Meio suporte de espuma de poliuretano envolta do bob.

Os meios suportes, bobs já recheados com a espuma de poliuretano, foram armazenados em uma bolsa de nylon, como mostra a Figura 4.10, com objetivo de facilitar o manuseio do mesmo, caso fosse necessária a retirada para realizar manutenção nos filtros. Foram usadas 985 unidades de meios suportes, sendo que no FAn necessitou-se de 694 unidades de suportes e no BAS foram 291 unidades.

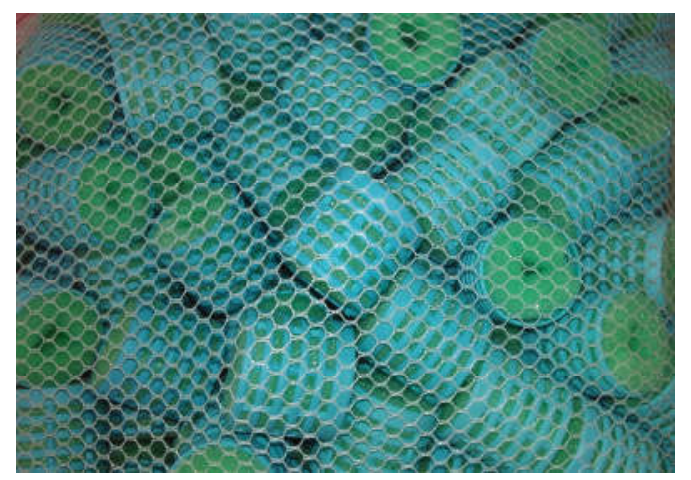

Figura 4.10: Meio suporte armazenado em bolsa de nylon 


\subsection{2 - Instalação}

A etapa de instalação do protótipo foi dividida em três atividades. A primeira delas foi à escolha do local para ser instalado o protótipo, que levou em consideração a viabilidade para a realização da pesquisa. A segunda foi o planejamento do processo de instalação do sistema e a terceira e última foi a execução do processo de instalação.

O modelo experimental foi construído e instalado no Laboratório de Saneamento Ambiental (LSA) do Programa de Pós-Graduação de Tecnologia Ambiental e Recursos Hídricos (PTARH) da Universidade de Brasília - UnB, como mostrado na Figura 4.11.

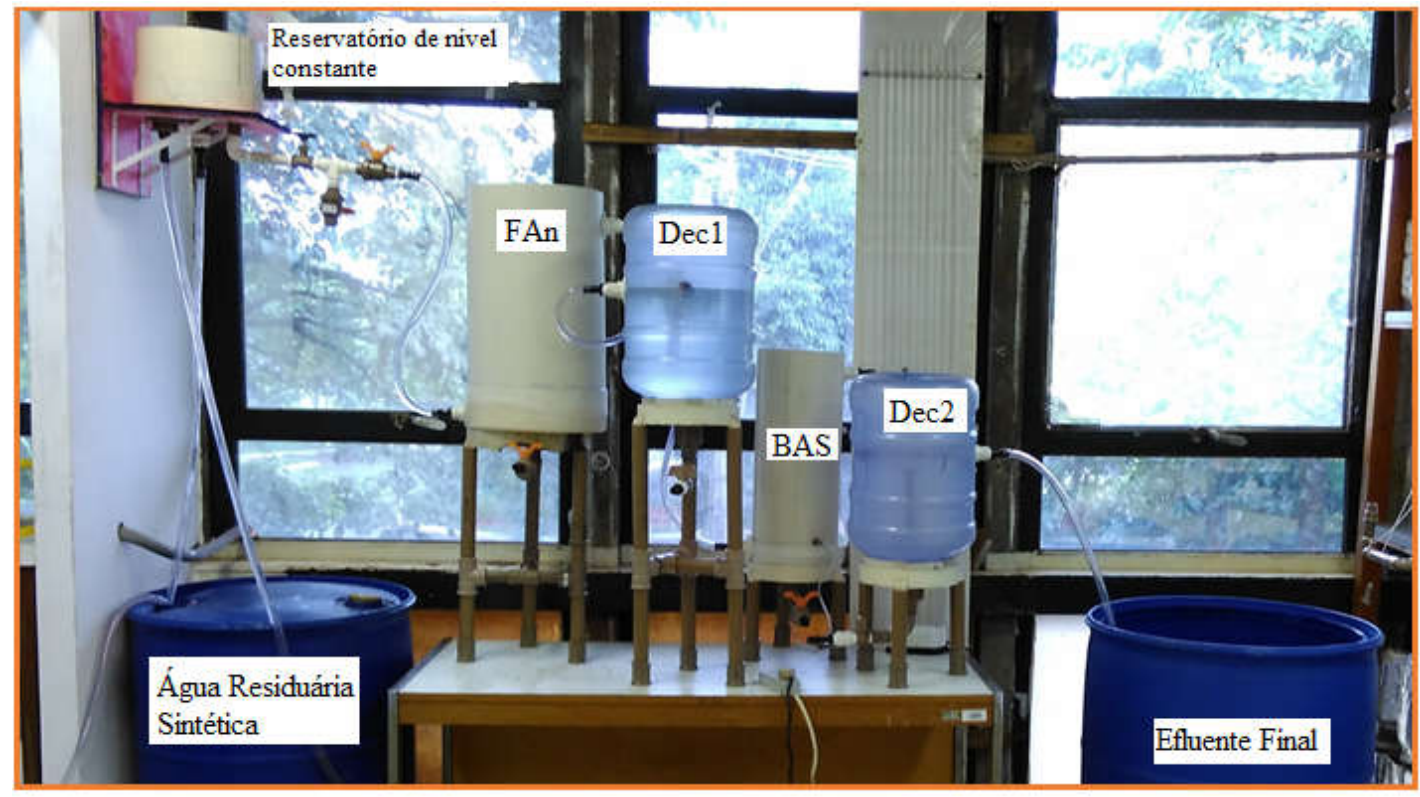

Figura 4.11: Sistema experimental construído e instalado

\section{3 - OPERAÇÃO, MANUTENÇÃO, CONTROLE E MONITORAMENTO DO SISTEMA DE TRATAMENTO DE ESGOTOS COMPOSTO PELOS PROCESSOS DE FILTRO ANAERÓBIO SEGUIDO DE BIOFILTRO AERADO SUBMERSO}

Esta etapa foi dividida em três fases. Após a instalação do sistema, deu-se início a primeira fase, a pré-operação, com objetivo de verificar possíveis vazamentos ou falhas no sistema. A fase seguinte foi a de partida do sistema, a terceira e última fase foi a de estabilidade e 
monitoramento, iniciada assim que cada filtro atingiu o percentual de remoção de DQO desejada.

\subsection{1 - Pré-Operação}

Inicialmente, encheram-se com água os filtros, sem o meio suporte, e decantadores, ficando em repouso por 24 horas, com a finalidade de verificar possíveis vazamentos. Foram testados também o compressor de ar (BAS) e a bomba submersa para verificar se atenderiam às necessidades do sistema.

Após serem corrigidos alguns vazamentos ocorridos, o sistema foi posto em operação contínua. Desta vez, os filtros operaram com o meio suporte, como mostrado na Figura 4.12. Foram verificados o desempenho da bomba submersa e compressor de ar, para uso ininterrupto, o comportamento do sistema, como por exemplo a conservação, regulação e controle da vazão pretendida, usando-se para isso a água de torneira como afluente.

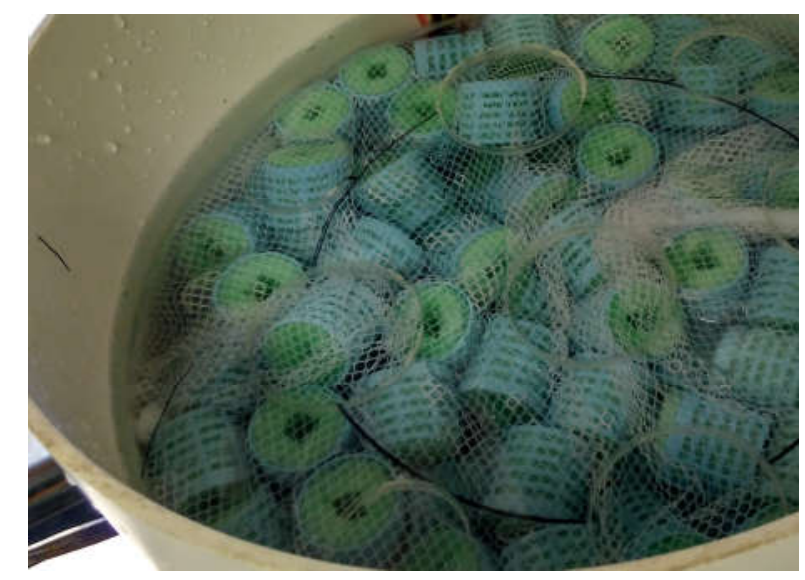

Figura 4.12: Vista superior do Filtro Anaeróbio em teste de operação

\subsection{2 - Água Residuária Sintética (ARS)}

Como o experimento foi realizado em escala de bancada, optou-se por utilizar um substrato sintético com composição orgânica e inorgânica similares a uma água residuária doméstica, a tomar por base a água residuária utilizada por Torres e Rodriguez (1996) e Moura (2011). 
Utilizou-se uma água residuária sintética com aproximadamente 800 mg.DQO.L ${ }^{-1}$, composta por proteínas (na forma de extrato de carne) e carboidratos de fácil e de difícil degradação (nas formas de sacarose e amido) contendo traços de metais e bicarbonato de sódio para tamponamento. Na Tabela 4.1 mostra-se a composição da ARS e na Tabela 4.2.

A água residuária sintética foi preparada contendo componentes e soluções enriquecidas com macro e micronutrientes devidos a compostos que estão presentes em águas residuárias domésticas.

Tabela 4.1: Composição da Água Residuária Sintética.

\begin{tabular}{|c|c|}
\hline COMPONENTE & $\begin{array}{c}\text { CONCENTRAÇÃO } \\
(800 \mathrm{mgDQO} / \mathrm{L})\end{array}$ \\
\hline \multicolumn{2}{|l|}{ Carboidratos (mg/L) } \\
\hline Sacarose & 77 \\
\hline Amido & 251 \\
\hline \multicolumn{2}{|l|}{ Proteínas (mg/L) } \\
\hline Extrato de Carne & 457 \\
\hline \multicolumn{2}{|l|}{ Solução de Sais (g/L) } \\
\hline $\mathrm{NaCl}$ & 100 \\
\hline $\mathrm{MgCl}_{2} \cdot 6 \mathrm{H}_{2} \mathrm{O}$ & 2,8 \\
\hline $\mathrm{CaCl}_{2} \cdot 2 \mathrm{H}_{2} \mathrm{O}$ & 1,8 \\
\hline \multicolumn{2}{|l|}{ Tampão (g/L) } \\
\hline $\mathrm{NaHCO3}$ & 1 \\
\hline
\end{tabular}

O modo de preparo usado foi adaptado a partir da metodologia utilizada por Torres e Rodriguez (1996) e Moura (2011), e constou do seguinte:

- Em um Becker misturava-se o extrato de carne e amido, solubilizava-se o material e então se autoclavava ( $121^{\circ} \mathrm{C}$ durante 15 minutos), para assegurar a completa dissolução e manutenção das características ao longo da operação. Deixava-se esfriar em temperatura ambiente. Este procedimento era feito no dia anterior a preparação do efluente.

- A solução de sais era preparada a partir da completa dissolução dos componentes citados na Tabela 4.1, em água destilada. Esta solução era mantida sob refrigeração. 
- A solução de micronutrientes era preparada a partir da completa dissolução dos componentes citados na Tabela 4.2, em água destilada. Esta solução era mantida resfriada.

Tabela 4.2: Composição da Solução de Micronutrientes

\begin{tabular}{|c|c|}
\hline COMPONENTE & CONCENTRAÇÃO (mg/L) \\
\hline \multicolumn{2}{|l|}{ Micronutrientes } \\
\hline $\mathrm{FeCl}_{3} .6 \mathrm{H}_{2} \mathrm{O}$ & 1,35 \\
\hline $\mathrm{MnCl}_{2} \cdot \mathbf{4} \mathrm{H}_{2} \mathrm{O}$ & 0,1 \\
\hline $\mathrm{CoCl}_{2} \cdot 6 \mathrm{H}_{2} \mathrm{O}$ & 0,024 \\
\hline $\mathrm{CaCl}_{2} \cdot 2 \mathrm{H}_{2} \mathrm{O}$ & 0,1 \\
\hline $\mathrm{ZnCl}_{2}$ anidro & 0,1 \\
\hline $\mathrm{CuCl}_{2} \cdot 2 \mathrm{H}_{2} \mathrm{O}$ & 0,025 \\
\hline $\mathrm{H}_{3} \mathrm{BO}_{3}$ & 0,01 \\
\hline $\begin{array}{c}\text { Molibdato de } \\
\text { sódio. } \mathrm{H}_{2} \mathrm{O}\end{array}$ & 0,024 \\
\hline $\mathrm{NaCl}$ & 1 \\
\hline $\mathrm{Na}_{2} \mathrm{SeO}_{3} .5 \mathrm{H}_{2} \mathrm{O}$ & 0,026 \\
\hline $\mathrm{NiCl}_{2} \cdot \mathbf{6} \mathrm{H}_{2} \mathrm{O}$ & 0,12 \\
\hline
\end{tabular}

- Após resfriada, a primeira solução era caracterizada de modo a obter as concentrações próximas a de uma água residuária doméstica, em termos de concentração de DQO. Deste modo, adicionava-se, em temperatura ambiente, $2,5 \mathrm{~mL} / \mathrm{L}$ da solução de sais, $1 \mathrm{~mL} / \mathrm{L}$ da solução de micronutriente, adicionava-se a sacarose e o bicarbonato de sódio de modo a perfazer as concentrações indicadas na Tabela 4.1.

- Agitava-se até a completa dissolução e mistura dos componentes.

Após preparada, a ARS era utilizada para alimentar o sistema e isso foi feito durante toda pesquisa. Essa ARS foi mantida em temperatura ambiente, com a temperatura mínima de $25^{\circ} \mathrm{C}$ e a máxima de $28,7^{\circ} \mathrm{C}$, por dificuldade de refrigeração de grandes volumes.

Eram produzidos diariamente, de segunda-feira a quinta-feira, 40 litros de água residuária sintética, e às sextas-feiras eram produzidos 120 litros, para alimentar o sistema durante o 
fim de semana. A ARS durava por um prazo máximo de três dias, e novamente era trocada, no intuito de evitar alterações significativas na caracterização da ARS produzida.

- A água residuária sintética fresca, ou seja, logo após ser preparada, possuía as seguintes características apresentadas na Tabela 4.3.

Tabela 4.3: Características da ARS

\begin{tabular}{cc}
\hline PARÂMETROS & $\begin{array}{c}\text { VALORES } \\
\text { MÉDIOS }\end{array}$ \\
\hline pH & 7,4 \\
\hline Temperatura $\left({ }^{\circ} \mathrm{C}\right)$ & 27,2 \\
\hline $\begin{array}{c}\text { Alcalinidade Total } \\
(\mathbf{m g C a C O 3} / \mathbf{L})\end{array}$ & 568 \\
DQO (mg/L) & 872 \\
\hline DBO (mg/L) & 406 \\
\hline SS (ml/L) & 0 \\
\hline
\end{tabular}

\subsection{3 - Partida do Sistema}

A fase de partida, normalmente longa, é o tempo necessário para formar, no meio suporte, a biomassa responsável pelo tratamento do esgoto, ou seja, é o tempo necessário para que o efluente obtenha características constantes.

Para acelerar esta fase, foi utilizado lodo anaeróbio e lodo aeróbio como inoculo no FAn e BAS, respectivamente, apresentados na Figura 4.13, procedente da Estação de Tratamento de Esgoto de Brasília - Asa Norte (ETEB-Norte), coletados do sistema de lodos ativados com reator configurado como Bardenpho ${ }^{\circledR}$, que tem divisão em zonas, havendo uma zona anaeróbia e uma zona aeróbia. $\mathrm{O}$ volume de lodo necessário para a inoculação, segundo Van Haandel e Lettinga (1994), varia de 10 a 30\% do volume do reator. 
O sistema entrou em operação no dia 24/02/2016 com a inoculação do lodo correspondente de $30 \%$ do volume útil dos filtros, ou seja, foi inserido, no FAn e no BAS, respectivamente, o volume aproximado de $6 \mathrm{~L}$ de lodo anaeróbio e $3 \mathrm{~L}$ de lodo aeróbio, cuja a caracterização está apresentada na Tabela 4.4.

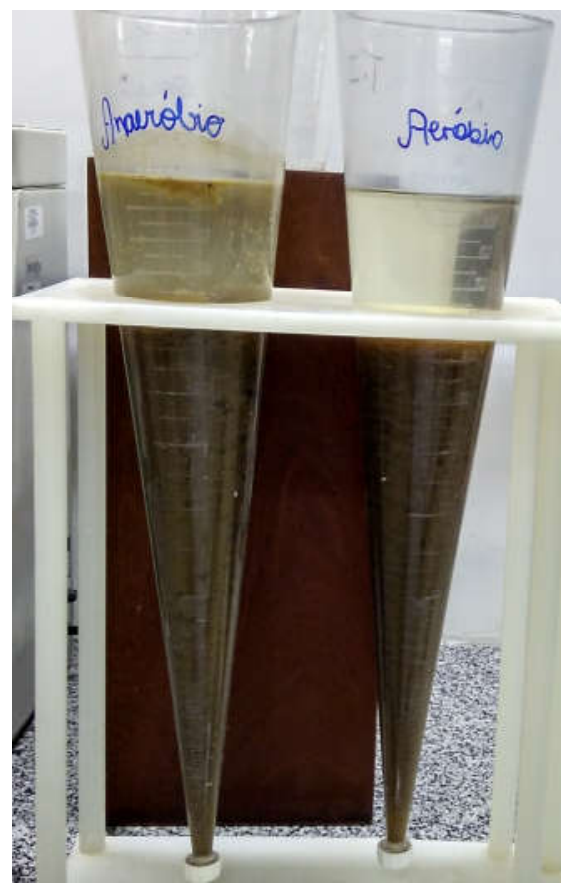

Figura 4.13: Lodo Utilizado para a Inoculação

Tabela 4.4: Caracterização do lodo da ETEB-Norte

\begin{tabular}{ccc}
\hline & LODO ANAERÓBIO & LODO AERÓBIO \\
\hline PARÂMETROS & \multicolumn{2}{c}{ VALORES } \\
\hline DQO (mg/L) & 6545 & 2885 \\
DBO (mg/L) & 122 & 386 \\
SSed (mL/L) & 600 & 600 \\
\hline
\end{tabular}

Após inserir os lodos provenientes da ETEB-Norte, o volume útil de ambos os filtros foi completado com a água residuária sintética, permanecendo em repouso por 36 horas, com aeração no BAS, conforme metodologia utilizada por Domingues (2005). O sistema 
começou a ser alimentado a uma vazão de $20 \mathrm{~mL} / \mathrm{min}$, menor que a vazão de projeto. $\mathrm{Ou}$ seja, nesta fase, o sistema foi submetido a uma carga orgânica menor do que aquela que o sistema é capaz de tratar, tendo um aumento de carga quando o sistema atingiu a estabilidade e a eficiência pretendida em projeto. Isso foi conseguido mediante o aumento da vazão e consequentemente redução do TDH.

Para determinar o momento ideal para alterar a vazão do sistema, acompanhou-se o comportamento do FAn, uma vez que o desenvolvimento e a taxa de crescimento da biomassa anaeróbia são menores se comparada à biomassa aeróbia. $\mathrm{O}$ monitoramento do filtro anaeróbio, apresentado na Tabela 4.5, baseou-se nas recomendações de Lettinga (1984) e de Chernicharo (1997).

Tabela 4.5: Condições desejáveis para estabilização do sistema.

\begin{tabular}{cc}
\hline PARÂMETRO & CONDIÇÃO DESEJÁVEL \\
\hline pH & Preferencialmente entre 6,8 e 7,2 \\
\hline $\begin{array}{c}\text { (DQmanda Química de Oxigênio } \\
\text { Alcalinidade Parcial (AP) }\end{array}$ & $\begin{array}{c}\text { Suficiente para manutenção do pH e } \\
\text { equilíbrio do sistema tampão. }\end{array}$ \\
\hline $\begin{array}{c}\text { Ácidos Graxo consequente aumento da } \\
\text { Relação AI/AP (AI = Alcalinidade } \\
\text { Intermediária) }\end{array}$ & Sempre abaixo de 200 mg HAc/L \\
\hline
\end{tabular}

Fonte: Lettinga (1984), Chernicharo (1997), adaptado.

Após o início da operação, durante o período de partida, que é o período referente à adaptação das bactérias inoculadas ao novo substrato, o desempenho do sistema foi acompanhado por uma rotina de análises dos parâmetros físicos e químicos, indicado na Tabela 4.6. As análises foram realizadas de acordo com os procedimentos descritos no 
Standard Methods for the Examination of Water and Wastewater (AWWA/APHA/WPCF, 1999).

Tabela 4.6: Parâmetros, métodos e frequência das análises durante a partida do sistema.

\begin{tabular}{|c|c|c|}
\hline PARÂMETRO & MÉTODO & FREQUÊNCIA \\
\hline pH & Potenciométrico & Diariamente \\
\hline Temperatura $\left({ }^{\circ} \mathrm{C}\right)$ & Sonda multiparâmetros & Diariamente \\
\hline $\begin{array}{l}\text { Alcalinidade Parcial } \\
\qquad\left(\mathrm{mg} \mathrm{CaCO}_{3} / \mathrm{L}\right)\end{array}$ & Titulométrico & $1 \mathrm{X} / \mathrm{semana}$ \\
\hline $\begin{array}{l}\text { Alcalinidade Total } \\
\quad(\mathrm{mg} \mathrm{CaCO} / \mathrm{L})\end{array}$ & Titulométrico & $1 \mathrm{X} /$ semana \\
\hline $\begin{array}{c}\text { Ácidos Graxos Voláteis } \\
\text { (mg HAc/L) }\end{array}$ & Titulométrico & $1 \mathrm{X} /$ semana \\
\hline $\begin{array}{l}\text { Demanda Química de } \\
\text { Oxigênio (mg/L) }\end{array}$ & Colorimétrico & $2 \mathrm{X} / \mathrm{semana}$ \\
\hline $\begin{array}{c}\text { Oxigênio Dissolvido (mg } \\
\left.\mathrm{O}_{2} / \mathrm{L}\right)\end{array}$ & Eletrométrico & $1 \mathrm{X} / \mathrm{semana}$ \\
\hline
\end{tabular}

\subsection{4 - Operação do Sistema Combinado}

À medida que o filtro anaeróbio atendeu as condições estabelecidas na Tabela 4.5, deu-se início à fase de operação do sistema combinado, que correspondeu a avaliação de desempenho do sistema combinado FAn seguido do BAS. Na rotina de monitoramento foram acrescentados outros parâmetros, apresentados na Tabela 4.7. Análises realizadas de acordo com os procedimentos descritos no Standard Methods for the Examination of Water and Wastewater (AWWA/APHA/WPCF, 1999).

Durante todo período de operação do sistema, não foi realizado nenhum procedimento de retrolavagem, e na operação, após a partida do sistema, o lodo do decantador, Dec 2, foi recirculado para a entrada do FAn, tornando assim o FAn a única fonte de geração de lodo. 
A recirculação ocorria uma vez por semana, onde eram coletados dois litros de lodo do fundo do Dec 2, mediam-se os sólidos sedimentáveis e se reinseria este lodo ao sistema.

Tabela 4.7: Parâmetros, métodos e frequência das análises durante a avaliação de desempenho do sistema

\begin{tabular}{|c|c|c|}
\hline PARÂMETRO & MÉTODO & FREQUÊNCIA \\
\hline pH & Potenciométrico & Diariamente \\
\hline Temperatura $\left({ }^{\circ} \mathrm{C}\right)$ & Sonda multiparâmetros & Diariamente \\
\hline Turbidez (NTU) & Nefelométrico & Diariamente \\
\hline Sólidos totais & Gravimétrico & $1 \mathrm{X} / \mathrm{semana}$ \\
\hline Sólidos totais voláteis & Gravimétrico & $1 \mathrm{X} /$ semana \\
\hline Sólidos totais fixos & Gravimétrico & $1 \mathrm{X} / \mathrm{semana}$ \\
\hline Sólidos suspensos totais & Gravimétrico & $1 \mathrm{X} / \mathrm{semana}$ \\
\hline Sólidos sedimentáveis & Gravimétrico & $1 \mathrm{X} /$ semana \\
\hline $\begin{array}{l}\text { Alcalinidade Parcial } \\
\left(\mathrm{mg} \mathrm{CaCO}_{3} / \mathrm{L}\right)\end{array}$ & Titulométrico & $1 \mathrm{X} /$ semana \\
\hline $\begin{array}{l}\text { Alcalinidade Total } \\
\text { (mg CaCO} \\
\text { (m) } / \mathrm{L})\end{array}$ & Titulométrico & $1 \mathrm{X} /$ semana \\
\hline $\begin{array}{l}\text { Demanda Química de } \\
\text { Oxigênio }(\mathrm{mg} / \mathrm{L})\end{array}$ & Colorimétrico & $2 \mathrm{X} /$ semana \\
\hline $\begin{array}{c}\text { Demanda Bioquímica } \\
\text { de Oxigênio }(\mathrm{mg} / \mathrm{L})\end{array}$ & Manométrico & $1 \mathrm{X} /$ semana \\
\hline $\begin{array}{c}\text { Oxigênio Dissolvido } \\
\left(\mathrm{mg} \mathrm{O} \mathrm{O}_{2} / \mathrm{L}\right)\end{array}$ & Eletrométrico & $1 \mathrm{X} / \mathrm{semana}$ \\
\hline
\end{tabular}

O método utilizado para medir a eficiência do sistema de tratamento biológico combinado, com o recheio de espuma de poliuretano envolto por anel de polipropileno, quanto à redução na produção de lodo, foi baseado na avaliação da eficiência de remoção de SST e DQO, a partir das análises de monitoramento realizadas. 


\subsection{5 - Pontos de Amostragem}

Os pontos de coleta das amostras para realizar as análises dos parâmetros físicos e químicos, estão apresentados na Figura 4.14, em que o ponto A representa o ponto de coleta de amostra da água residuária sintética afluente, após homogeneização manual; o ponto $\mathrm{B}$ representa o ponto de coleta de amostra realizada aproximadamente $2 \mathrm{~cm}$ abaixo da superfície de saída do FAn; o ponto C representa o ponto de coleta de amostra realizada aproximadamente $2 \mathrm{~cm}$ abaixo da superfície do Dec 1; o ponto D representa o ponto de coleta de amostra realizada na entrada do BAS; o ponto E representa o ponto de coleta de amostra realizada aproximadamente $2 \mathrm{~cm}$ abaixo da superfície de saída do BAS e o ponto F representa o ponto de coleta de amostra na saída do Dec 2.

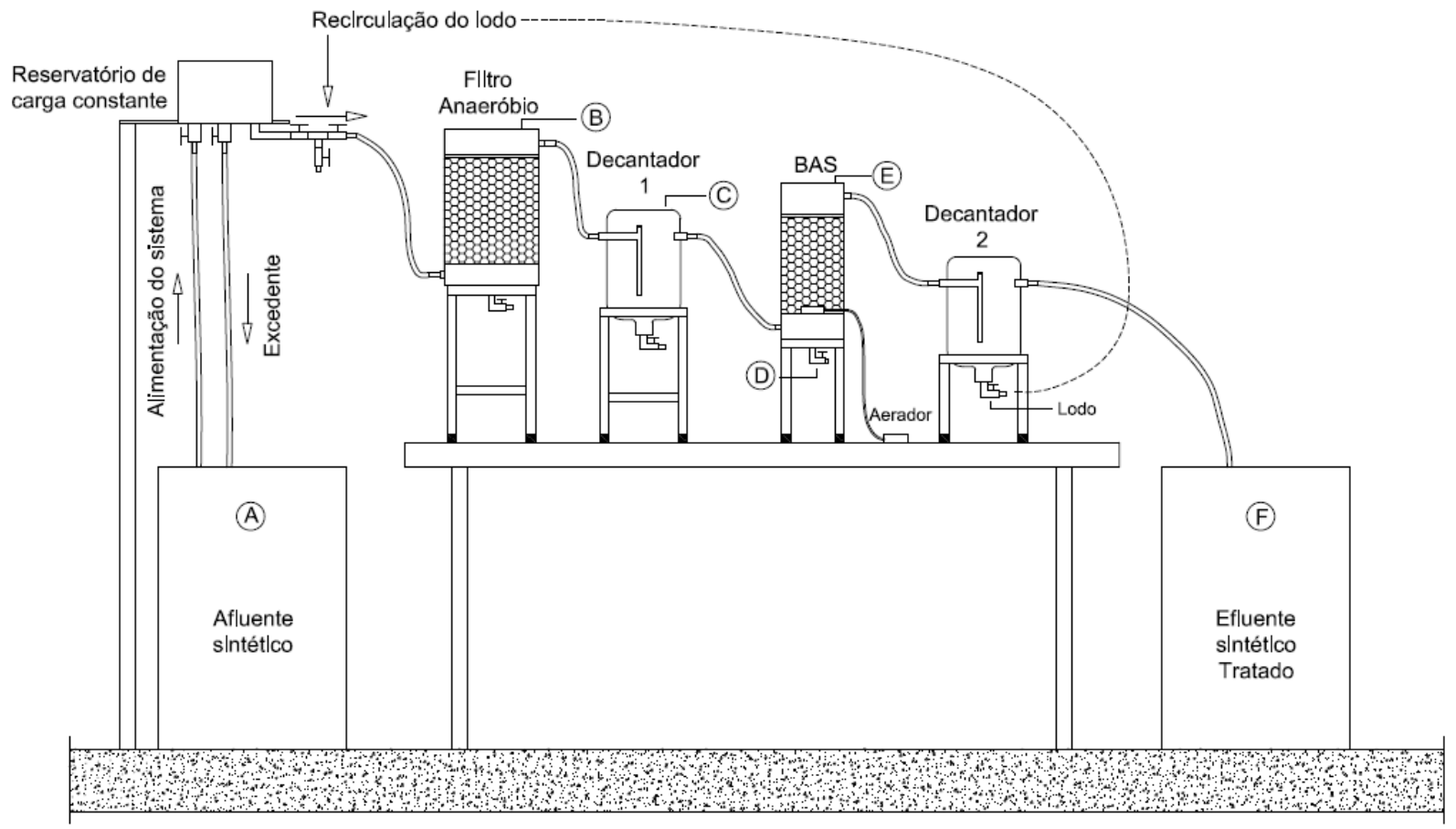

Figura 4.14: Pontos de coleta de amostra 


\subsection{6 - Caracterização Quantitativa e Qualitativa da Biomassa}

Ao final da operação do sistema combinado foi realizada a caracterização quantitativa da biomassa em suspensão e aderida à espuma de poliuretano e aos anéis de polipropileno (bob), em termos de sólidos totais e voláteis, no FAn e no BAS. Assim como foram identificados os diferentes grupos de protozoários e metazoários presentes na biomassa em suspensão e aderida à espuma de poliuretano e aos anéis de polipropileno (bob), do BAS. A metodologia utilizada foi adaptada das metodologias utilizadas por Agra (2009), Fuji (2011) e Correa (2014).

4.3.6.1 - Quantificação da biomassa aderida ao meio suporte do Filtro Anaeróbio e do Biofiltro Aeróbio Submerso

Primeiramente fez-se a pesagem dos meios suportes secos, cuja finalidade foi quantificar a biomassa aderida ao meio suporte durante o período de operação.

Foi realizada a coleta de 50 unidades do meio suporte de cada filtro. O meio suporte ficou em repouso (escorrendo) por um período de 2 horas para retirada do líquido excedente. Após esse período, os bobs com espuma de poliuretano foram pesados, divididos em 5 amostras, cada uma com 10 unidades, como mostrado na Figura 4.15.

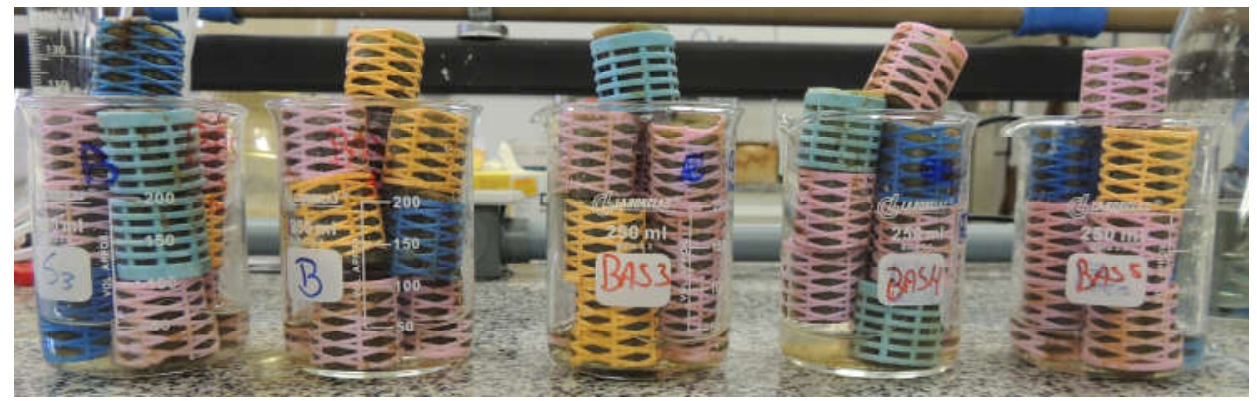

Figura 4.15: Amostras de meio suporte com biomassa aderida.

A pesagem, em balança analítica, foi realizada com uma amostra de cada vez contendo os 10 os bobs com espuma de poliuretano. O intuito dessa pesagem foi obter o valor do peso da biomassa aderida, juntamente com o peso da espuma de poliuretano umedecida (após o repouso de 2 horas). 
Após a pesagem, realizou-se o processo de extração manual da biomassa aderida na espuma de poliuretano e no bob, respectivamente por compressão e de raspagem com o auxílio de escovas de uso odontológico e água deionizada. A biomassa extraída foi acondicionada em Beckers de $500 \mathrm{~mL}$. Cada unidade de meio suporte foi raspada em suas superfícies externa e interna. Após cada extração, era coletada uma alíquota de $100 \mathrm{~mL}$ para a análise de sólidos totais e voláteis conforme o Standard Methods for the Examination of Water and Wastewater (AWWA/APHA/WPCF, 1999).

Previamente, foram umedecidas 10 unidades novas de espuma de poliuretano envolta em anel de polipropileno em água deionizada, que ficaram em repouso durante 2 horas para retirada do excesso de líquido, em seguida, sendo encaminhado para a pesagem em balança analítica, com intuito de obter o valor do peso da unidade de meio suporte com a espuma úmida. Para se obter o peso do meio suporte seco realizou-se a pesagem deles após repouso de 2 horas.

4.3.6.2 - Quantificação da biomassa em suspensão do Filtro Anaeróbio e Biofiltro Aeróbio Submerso

Foi realizada a coleta da biomassa em suspensão, obtidas nos coletores de fundo de cada filtro. Foram coletadas 5 alíquotas de $250 \mathrm{~mL}$ de cada filtro, como mostrado na Figura 4.16. Inicialmente, foi realizada uma expurga no sistema pelos coletores de fundo para a retirada das amostras da biomassa em suspensão.

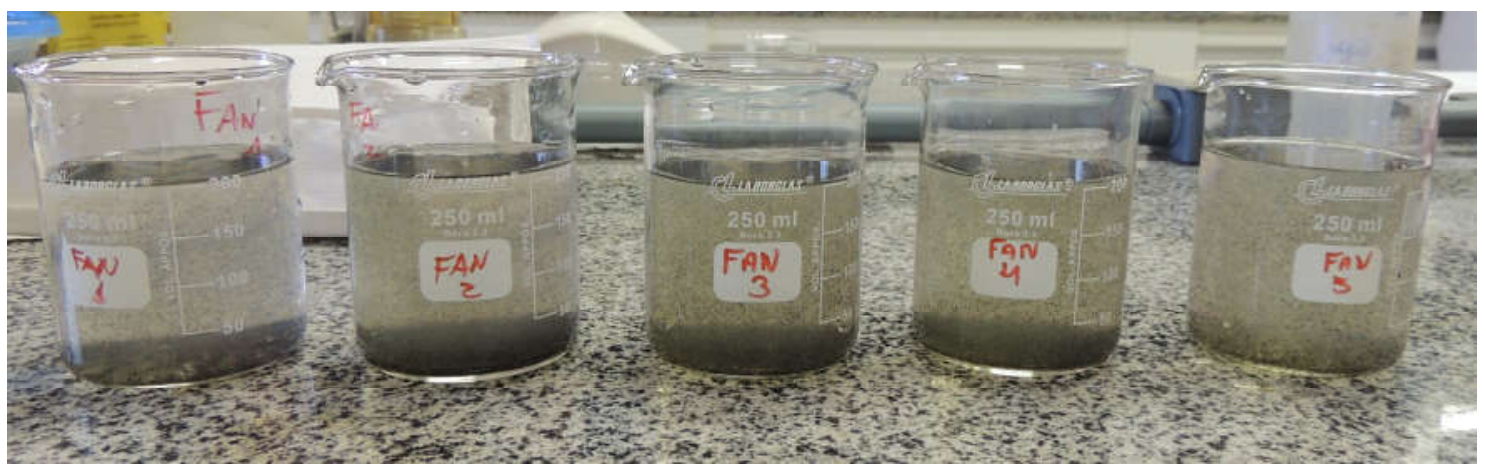

Figura 4.16: Amostras da biomassa em suspensão retiradas do fundo do FAn. 
Após a homogeneização das 5 alíquotas de $250 \mathrm{~mL}$, retiraram-se $100 \mathrm{~mL}$ da amostra para a análise de sólidos totais e voláteis.

\subsubsection{3 - Análise Microbiológica do Biofiltro Aeróbio Submerso}

A análise da microfauna existente no biofiltro aeróbio submerso foi realizada na biomassa aderida e na biomassa em suspensão.

Foram coletadas, de forma manual, 2 amostras, em Beckers de 250mL, com 5 unidades do meio suporte do biofiltro aeróbio submerso. Em seguida, realizou-se o processo de extração manual da biomassa aderida aos bobs e da espuma de poliuretano, mediante de compressão e raspagem com o auxílio de escovas de uso odontológico e água deionizada, recolhidos em Beckers de $250 \mathrm{~mL}$, como mostrado na Figura 4.17. Cada elemento foi raspado em suas superfícies externa e interna. O mesmo processo de extração foi realizado utilizando o próprio efluente, em vez de água deionizada.

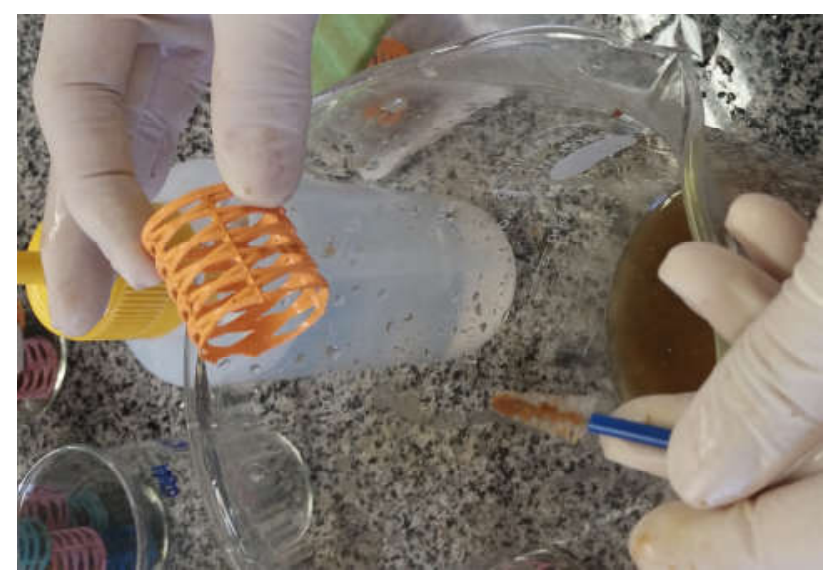

Figura 4.17: Raspagem manual com o auxílio de escovas de uso odontológico

Após a homogeneização das amostras, foram coletadas subamostras, com o auxílio de uma pipeta de $5 \mathrm{~mL}$, e transferidas para câmaras de Sedwick-Rafter com capacidade de 1,0 mL de volume para quantificação dos microrganismos em microscópio. Foram realizadas 2 contagens por amostra, totalizando 8 leituras. 
As amostras da biomassa em suspensão foram obtidas do coletor de fundo do BAS. Foram coletadas 4 alíquotas de $250 \mathrm{~mL}$, totalizando 1 litro. Anteriormente, foi realizada uma purga no sistema pelo coletor de fundo para a retirada das amostras da biomassa em suspensão.

Após a homogeneização das 4 alíquotas de $250 \mathrm{~mL}$, retiraram-se $100 \mathrm{~mL}$ da amostra e em seguida $1 \mathrm{~mL}$, com o auxílio de uma pipeta de $5 \mathrm{~mL}$, que foi transferida para câmaras de Sedwick-Rafter com capacidade de 1,0 mL de volume para quantificação da diversidade biológica em microscópio. Foram realizadas 2 contagens por amostra. Ao total, nessa etapa foram realizadas 10 leituras.

\subsection{7 - Produção de Lodo Gerado pelo Sistema Combinado}

A produção de lodo gerado pelo sistema combinado, FAn seguido de BAS, foi estimada através do cálculo do coeficiente de produção de sólidos expresso pela Equação (4.7)

$$
Y=\frac{S S T}{D Q O_{\text {aplicada }}}
$$

Equação (4.7)

$\mathrm{Na}$ Equação (4.7) o Y é o coeficiente de produção de sólidos, expresso em $\mathrm{KgSST} / \mathrm{Kg}$, SST são os sólidos suspensos totais, expressos em mg/L, e DQO ${ }_{\text {aplicada }}$ é a DQO afluente, expressa em mg/L.

Após calcular o coeficiente de produção de sólidos (Y), foi então estimada a produção de lodo gerado em cada filtro, através da Equação (4.8).

$$
P=Y \times D Q O_{\text {aplicada }}
$$


$\mathrm{Na}$ Equação (4.8), P é a produção de lodo, expressa em $\mathrm{KgSST} / \mathrm{d}$, Y é o coeficiente de produção de sólidos, expresso em $\mathrm{KgSST} / \mathrm{KgDQO}_{\text {aplicada, }}$ e $\mathrm{DQO}_{\text {aplicada }}$ é a carga de DQO aplicada, expressa em $\mathrm{kgDQO} / \mathrm{d}$.

Em que a Carga de DQO aplicada calcula-se pela Equação (4.9).

$$
D Q O_{\text {aplicada }}=Q_{\text {média }} \times S_{o}
$$

$\mathrm{Na}$ Equação (4.9), Qmédia é a vazão média afluente, expressa em m³/d, e $\mathrm{S}_{\mathrm{o}}$ é a concentração de DQO afluente, expressa em mg/L.

A produção per capita da Carga de SST é calculada pela Equação (4.10).

$$
\text { Carga SS per capita }=\frac{P}{h a b}
$$

Equação (4.10)

Na Equação (4.10), hab é o número de habitantes.

\section{4 - ANÁLISE E DISCUSSÃO DOS RESULTADOS OBTIDOS}

Para avaliar o sistema de bancada e a tecnologia propostos, os dados foram analisados empregando ferramentas estatísticas, aplicando estatística descritiva dos dados de cada característica de qualidade da água residuária analisada. Calculando o número de dados analisados, a média aritmética e geométrica, a mediana, os valores máximos e mínimos, e percentis $10,25,75$ e $90 \%$.

Os resultados obtidos foram comparados com dados já obtidos em outros trabalhos. Para tal comparação, propôs-se a avaliação da eficiência de tratamento e do desempenho operacional do sistema.

Os microrganismos avaliados na biomassa do BAS foram identificados e classificado conforme a sistemática de Canler et al.(1999), Madoni (1994) e Streble e Krauter (1987). 


\section{5 - RESULTADOS E DISCUSSÃO}

\section{1 - ÁGUA RESIDUÁRIA SINTÉTICA}

A água residuária sintética, usada no sistema FAn-BAS, reproduziu as características de um esgoto doméstico unifamiliar. Como bases tomaram-se as características do esgoto doméstico unifamiliar utilizado no sistema concebido e analisado por Achaval (2014). Na Tabela 5.2 estão apresentadas as características desse esgoto doméstico, previamente tratado por Tanque Imhoff modificado e da água residuária sintética reproduzida e utilizada durante os 115 dias de operação do sistema FAn-BAS.

A temperatura e o pH são parâmetros bastante relevantes, por interferirem na atividade microbiana, podendo afetar o equilíbrio entre as espécies e todo o sistema de degradação do processo anaeróbio, que apresenta melhor desempenho quando o esgoto possui temperaturas maiores que $20^{\circ} \mathrm{C}$ e $\mathrm{pH}$ próximo à neutralidade, condições estas consideradas satisfatórias para manutenção das atividades microbianas do sistema concebido.

A ARS atendeu satisfatoriamente quanto ao parâmetro temperatura, o que resultou do período de operação coincidir com as boas condições climáticas para tal, uma vez que a ARS ficou armazenada em bombonas de 200 litros, em temperatura ambiente.

$\mathrm{O}$ controle do $\mathrm{pH}$ próximo à neutralidade é importante, pois pode reduzir o período de partida, além de que as archeas metanogênicas sobrevivem a um pH ótimo entre 7,0 e 7,2 e as bactérias acidogênicas, entre 5,8 e 6,2. Se há grande decréscimo no $\mathrm{pH}$, ocorrerá uma diminuição da taxa de crescimento das archeas metanogênicas, aumentando a concentração de ácidos voláteis, o que indica que a etapa acidogênica prevalece.

Já no que se referiu ao $\mathrm{pH}$, algumas amostras apresentaram valores acima do esperado, o que pode ter interferido no tempo de partida, ou seja, caso houvesse um controle maior nesse parâmetro, o tempo de partida poderia ter sido menor, apesar de que os valores medidos tenham ficado próximos aos valores de $\mathrm{pH}$ ótimo entre 7,0 e 7,2. 
A alcalinidade e o nitrato apresentaram concentrações maiores que as apresentadas pela água residuária utilizada por Achaval (2014), que já era mais concentrado do que a literatura indica, que seria de $200 \mathrm{mg} \mathrm{CaCO} / \mathrm{L}$ para alcalinidade e o nitrato próximo a zero (Von Sperling, 2005).

A alta alcalinidade indica uma elevada capacidade de tamponamento, ou seja, a manutenção do $\mathrm{pH}$ próximo à neutralidade, o que favorece o bom desempenho do FAn. Como o pH manteve-se abaixo de 8,3, pode-se dizer que a água residuária sintética apresentou apenas concentrações de bicarbonatos.

A caracterização, quanto às concentrações de sólidos, da ARS está apresentada na Tabela 5.1 .

Tabela 5.1: Concentrações da série de sólidos presentes na ARS.

\begin{tabular}{|c|c|c|c|c|c|}
\hline & $\begin{array}{l}\text { Número de } \\
\text { amostras }\end{array}$ & Média & Mediana & Máx. & Min. \\
\hline Sólidos Totais - ST (mg/L) & 16 & 1299 & 1275 & 1994 & 553 \\
\hline $\begin{array}{l}\text { Sólidos Totais Voláteis - STV } \\
\text { (mg/L) }\end{array}$ & 16 & 908 & 845 & 1781 & 301 \\
\hline Sólidos Totais Fixos - STF (mg/L) & 16 & 391 & 407 & 898 & 206 \\
\hline $\begin{array}{l}\text { Sólidos Suspensos Totais - SST } \\
(\mathrm{mg} / \mathrm{L})\end{array}$ & 16 & 111 & 118 & 222 & 28 \\
\hline
\end{tabular}

Como se pode observar, de maneira geral, não foram mantidas as mesmas concentrações do esgoto utilizado por Achaval (2014), esses desvios dos valores dos parâmetros podem ser justificados pelo uso de diferentes marcas do composto extrato de carne. Já a condutividade elevada deu-se pela alta concentração de sais utilizada pela metodologia para reproduzir de ARS. Vale ressaltar que concentrações de DQO apresentadas na Tabela 5.2 são resultantes de análises feitas no mesmo dia da preparação da ARS. 
Tabela 5.2: Características do esgoto doméstico unifamiliar, previamente tratado por Tanque Imhoff Modificado e da Água Residuária Sintética.

\begin{tabular}{|c|c|c|c|c|c|c|c|c|c|c|}
\hline \multicolumn{6}{|c|}{ Tanque Imhoff Modificado } & \multicolumn{5}{|c|}{ Água Residuária Sintética } \\
\hline & $\begin{array}{c}\text { Número } \\
\text { de } \\
\text { amostras }\end{array}$ & Média & Mediana & Máx. & Min. & $\begin{array}{l}\text { Número de } \\
\text { amostras }\end{array}$ & Média & Mediana & Máx. & Min. \\
\hline Temperatura $\left({ }^{\circ} \mathrm{C}\right)$ & 43 & 23,36 & 23,8 & 25,6 & 19,5 & 23 & 27,2 & 27,6 & 28,7 & 25 \\
\hline pH & 43 & 6,61 & 6,61 & 6,94 & 6,07 & 44 & 7,4 & 7,3 & 6,5 & 8,3 \\
\hline $\begin{array}{l}\text { Alcalinidade } \\
(\mathrm{mgCaCO3} / \mathrm{L})\end{array}$ & 43 & 254,88 & 257,5 & 390 & 100 & 9 & 543 & 519 & 643 & 435 \\
\hline $\begin{array}{l}\text { Condutividade } \\
(\mu \mathrm{S} / \mathrm{cm})\end{array}$ & 43 & 582,43 & 551 & 842 & 372 & 41 & 82 & 55 & 447 & 30 \\
\hline $\mathrm{DBO}_{5}(\mathrm{mg} / \mathrm{L})$ & 32 & 491,25 & 468 & 664 & 230 & 44 & 1409,3 & 1387 & 1967 & 1093 \\
\hline DQO (mg/L) & 32 & 919,95 & 885 & 1355 & 618 & 7 & 406 & 412 & 488 & 328 \\
\hline SST & 11 & 142,03 & 136 & 176 & 108 & 33 & 872 & 840 & 1009 & 751 \\
\hline
\end{tabular}


Avaliando as concentrações obtidas nas análises das séries de sólidos (ST, STV, STF e SST) da ARS, pode-se dizer que a ARS reproduziu as características quanto aos ST e STF, apresentando uma concentração maior quanto a STV e uma concentração menor para SST dos esgotos domésticos, que segundo Von Sperling (2005), está na faixa de 700 - 1350 $\mathrm{mg} / \mathrm{L}$, os STV na faixa de $365-700 \mathrm{mg} / \mathrm{L}$, os STF na de $340-50 \mathrm{mg} / \mathrm{L}$ e os SST na faixa de $200-450 \mathrm{mg} / \mathrm{L}$.

A água residuária sintética caracterizada neste item, foi utilizada como afluente do sistema combinado durante toda sua operação que iniciou em 24/02/2016 e terminou no dia 17/06/2016. A operação foi dividida em duas fases, a fase 2 referente ao tempo de duração da estabilização do sistema e a fase 3 referente ao tempo de operação com o sistema estável, fase em que foram realizadas as análises físico-químicas para avaliar a eficiência do sistema de tratamento proposto. Na Tabela 5.3 estão apresentadas as características operacionais pertinentes a cada fase do sistema global.

Tabela 5.3: Características operacionais de cada fase

\begin{tabular}{lcc}
\hline & \multicolumn{2}{c}{ Fase } \\
\hline Características & $\mathbf{2}$ & $\mathbf{3}$ \\
Vazão & $20 \mathrm{~mL} / \mathrm{min}$ & $27 \mathrm{~mL} / \mathrm{min}$ \\
TDH & $2,4 \mathrm{~d}$ & $1,2 \mathrm{~d}$ \\
Início & $24 / 02 / 2016$ & $12 / 04 / 2016$ \\
Duração & $48 \mathrm{~d}$ & $67 \mathrm{~d}$ \\
\hline
\end{tabular}

\section{2 - AVALIAÇÃO DO DESEMPENHO DO SISTEMA DURANTE A PARTIDA}

Esta fase teve duração de 48 dias, apresentando grande instabilidade quanto à remoção de DQO. O sistema começou a apresentar estabilidade entre o $17^{\circ}$ e o $24^{\circ}$ dia de operação, quando avaliado de maneira global, porém apresentou maior estabilidade após a partida do FAn, que ocorreu entre os dias $45^{\circ}$ e $49^{\circ}$, quando os resultados são analisados isoladamente, como se pode observar na Figura 5.1. 
Durante toda a operação do sistema combinado, a concentração de OD no BAS manteve-se acima de $2 \mathrm{mg} / \mathrm{L}$, na unidade BAS, visando garantir a condição favorável ao desenvolvimento da biomassa aeróbia heterotrófica.

Em relação à remoção de DQO, os resultados apresentados pelo sistema podem ser considerados satisfatórios, a eficiência alcançou $80 \%$ no início da fase de partida e manteve-se acima deste valor durante todo período avaliado.

Observando-se a Figura 5.1, o tempo de partida do sistema ficou dentro do esperado, tomando por base o sistema experimental de Domingues (2005), que apresentou maior estabilidade no sistema FA-BAS por volta do $28^{\circ}$ dia, enquanto o FA, isolado, por volta do $54^{\circ}$ dia. Após o período de partida do sistema, observado no dia 12/04/2016, deu-se início à fase de estabilidade operacional.

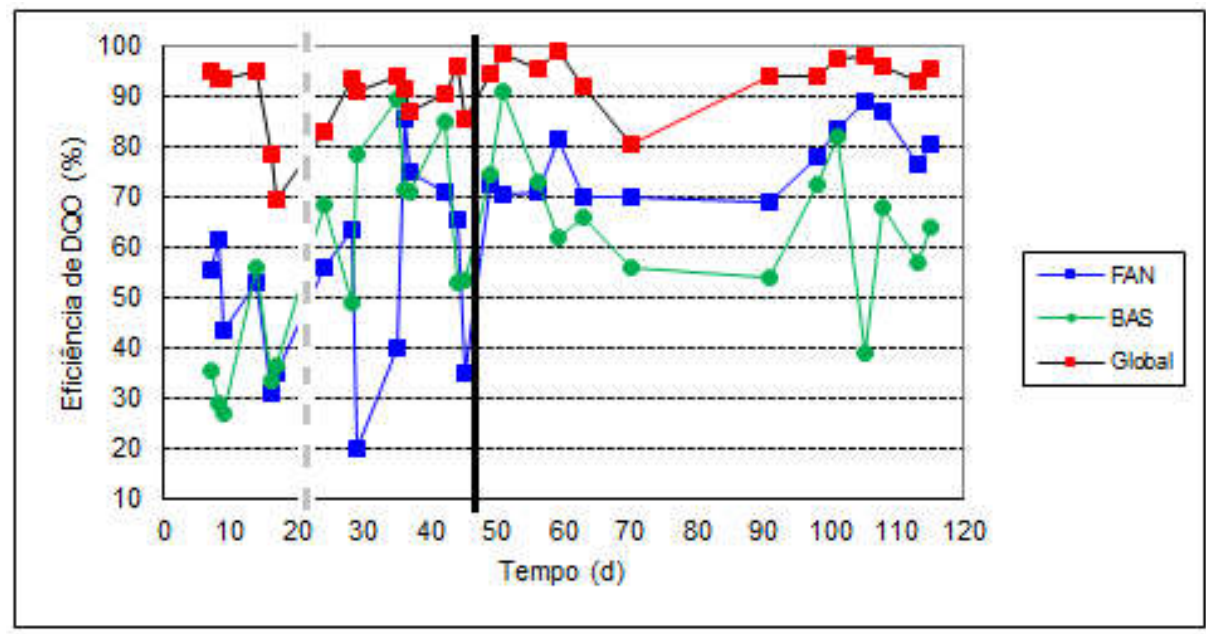

Figura 5.1: Gráfico do comportamento das eficiências de remoção de DQO nos efluentes de cada filtro, e do sistema combinado, ao longo do período de operação.

A estabilidade do sistema confirmou-se no $49^{\circ}$ dia de operação, uma vez que além da eficiência de remoção de DQO, o sistema atendeu também aos demais parâmetros condicionais, como a relação AI/AP $(\leq 0,30)$, ácidos graxos ( $200 \mathrm{mgHAc} / \mathrm{L})$ e a alcalinidade elevada, garantindo a manutenção do $\mathrm{pH}$ próximo à neutralidade. Na Tabela 5.4 podem-se observar a média, valor máximo e valor mínimo de cada parâmetro analisado nesta fase. 
Durante a partida, o pH na unidade FAn variou entre 8,2 e 6,8, com valor médio de 7,2. Este resultado encontra-se na faixa de $\mathrm{pH}$ considerada ótima para digestão anaeróbia, situada entre 6,8 e 7,5 .

Os valores de ácidos graxos voláteis, durante todo período, mantiveram-se dentro da faixa considerada ideal ( de $200 \mathrm{mgHAc} / \mathrm{L}$ ). Quanto à relação $\mathrm{AI} / \mathrm{AP}$, os valores estiveram acima do valor ideal $(0,30)$ na maior parte do tempo, indicando a instabilidade do sistema, em acordo com os demais parâmetros que indicavam a instabilidade do sistema.

Tabela 5.4: Média, valores máximos e valores mínimos dos parâmetros relevantes a fase 2

ARS

\section{Média \pm DP}

$27,3 \pm 1,1$

$7,4 \pm 0,5$

$8,3-6,7$

pH

Temperatura $\left({ }^{\circ} \mathrm{C}\right)$

H

(2)

(

Alc. Total (mgCaCO3/L)

$543 \pm 86$

$643-435$

$633 \pm 124$

$780-400$

Alc. Parcial (mgCaCO3/L)

Ácidos Graxos (mgHAc/L)

$439 \pm 104$

$555-305$

$464 \pm 96$

$610-293$

Efluente FAn

$0,4-0,1$

$0,4 \pm 0,1$

$0,2-0,5$

DQO (mg/L)

$735 \pm 174$

$1009-435$

$392 \pm 207$

$903-85$ 


\section{3 - Avaliação do Desempenho do Sistema Combinado após a Partida}

A avaliação teve início no $49^{\circ}$ dia de operação, logo após a avaliação de partida do FAn, e compreendeu um período de 67 dias, cujas condições operacionais que estão apresentadas na Tabela 5.5. Onde o TDH global do sistema combina foi de 1,2 dias, em que o FAn operou com TDH de 12 horas, o BAS com TDH de 4,8 horas e cada decantador operou com TDH de 6 horas.

Tabela 5.5: Características de avaliação de desempenho global do sistema combinado.

\begin{tabular}{cc}
\hline Características & Valores \\
\hline Vazão & $27 \mathrm{~mL} / \mathrm{min}$ \\
TDH & $1,2 \mathrm{~d}$ \\
Início & $12 / 04 / 2016$ \\
Duração & $67 \mathrm{~d}$ \\
\hline
\end{tabular}

Nesta fase da operação, deu-se início à recirculação do lodo proveniente do Dec 2 (efluente do BAS), realizada semanalmente. O reciclo era feito manualmente com volume de dois litros, inserido na entrada do FAn, sendo que antes era realizada a quantificação de sólidos sedimentáveis, o que é mostrado na Figura 5.2.

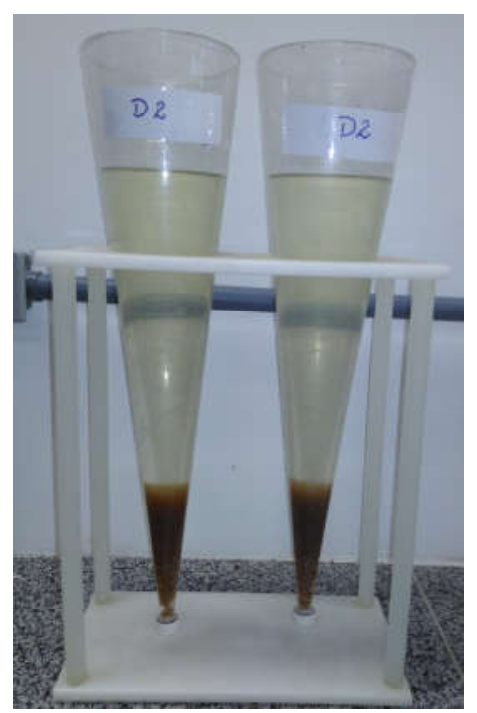

Figura 5.2: Análise de sólidos sedimentáveis do lodo do Dec 2. 
$\mathrm{Na}$ Tabela 5.6 está apresentado um resumo dos valores obtidos para os parâmetros de maior interesse empregados para avaliar o sistema combinado FAn-BAS, com as respectivas faixas de variação, médias aritméticas e desvios padrão.

Tabela 5.6: Variação dos valores obtidos para os parâmetros empregados na avaliação do Sistema.

\begin{tabular}{|c|c|c|c|c|c|c|}
\hline & \multicolumn{2}{|c|}{ ARS } & \multicolumn{2}{|c|}{ Efluente FAn } & \multicolumn{2}{|c|}{ Efluente BAS } \\
\hline & Média $\pm D P$ & Variação & Média $\pm D P$ & Variação & Média \pm DP & Variação \\
\hline $\begin{array}{l}\text { Temperatura } \\
\left({ }^{\circ} \mathrm{C}\right)\end{array}$ & $27,5 \pm 1$ & $28,5-25$ & $27 \pm 1$ & $28,3-25,2$ & $26,8 \pm 1$ & $28,3-24,6$ \\
\hline pH & $7,4 \pm 0,4$ & $8,1-6,5$ & $7,3 \pm 0,3$ & $8,0-6,8$ & $7,7 \pm 0,3$ & $8,2-7,2$ \\
\hline $\begin{array}{l}\mathrm{OD} \\
\left(\mathrm{mgO}_{2} / \mathrm{L}\right)\end{array}$ & - & - & - & - & $4,5 \pm 0,7$ & $5,2-3,1$ \\
\hline $\begin{array}{l}\text { Turbidez } \\
\text { (NTU) }\end{array}$ & $82 \pm 74$ & $447-30$ & $35 \pm 17$ & $90-12$ & $2 \pm 2,2$ & $12-0,5$ \\
\hline $\begin{array}{l}\mathrm{AT} \\
(\mathrm{mgCaCO3} / \mathrm{L})\end{array}$ & $543 \pm 86$ & $643-435$ & $584 \pm 14$ & $680-573$ & $415 \pm 104$ & $531-330$ \\
\hline DQO (mg/L) & $599 \pm 165$ & $928-350$ & $138 \pm 55$ & $245-52$ & $48 \pm 32$ & $113-13$ \\
\hline $\mathrm{DBO}_{5}(\mathrm{mg} / \mathrm{L})$ & $406 \pm 49$ & $488-328$ & $71 \pm 38$ & $149-45$ & $14 \pm 3$ & $18-9$ \\
\hline ST (mg/L) & $1299 \pm 325$ & 1994-553 & $1057 \pm 320$ & $1695-256$ & $1411 \pm 224$ & 1411-309 \\
\hline STV (mg/L) & $908 \pm 344$ & $1781-301$ & $776 \pm 266$ & $1365-153$ & $747 \pm 258$ & $1261-4$ \\
\hline STF (mg/L) & $391 \pm 171$ & 898-206 & $281 \pm 121$ & $453-103$ & $277 \pm 113$ & $457-102$ \\
\hline SST (mg/L) & $111 \pm 49$ & $222-28$ & $51 \pm 47$ & $173-8$ & $18 \pm 5$ & $59-1$ \\
\hline
\end{tabular}

$\mathrm{Na}$ Tabela 5.7, estão discriminados os resultados obtidos nas análises de sólidos sedimentáveis realizadas antes de cada reciclo. Esta operação de recirculação do lodo proveniente do Dec 2, foi realizada oito vezes, ao todo foram 16 litros de lodo, sendo 124 $\mathrm{mg} / \mathrm{L}$ de lodo sedimentado. 
Tabela 5.7: Quantificação de Sólidos Sedimentados Recirculado. (N=8)

\begin{tabular}{cc}
\hline Dia & SSed (mg/L) \\
\hline $\mathbf{5 3}^{\circ}$ & 47 \\
\hline $\mathbf{5 8}^{\mathbf{o}}$ & 14 \\
\hline $\mathbf{6 5}^{\mathbf{0}}$ & 20 \\
\hline $\mathbf{7 2}^{\mathbf{0}}$ & 8 \\
\hline $\mathbf{8 0}^{\mathbf{0}}$ & 10 \\
$\mathbf{8 6}^{\mathbf{0}}$ & 6 \\
\hline $\mathbf{9 4}^{\mathbf{0}}$ & 9 \\
\hline $\mathbf{1 0 4}^{\mathbf{0}}$ & 10 \\
\hline
\end{tabular}

\subsection{1 - Avaliação Geral das Condições Ambientais}

Observando-se a que apresenta os resultados obtidos para os parâmetros físicos e químicos, pode-se concluir que as condições ambientais desejáveis à manutenção da biomassa (anaeróbia e aeróbia) foram atendidas. No FAn, a faixa de pH desejável para a manutenção da estabilidade da metanogênese após a partida (entre 6,0 e 8,0) foi mantida. A estabilidade do sistema tampão no FAn foi indicada pela elevação nos valores da alcalinidade em relação aos valores da ARS e pela manutenção dos valores dos ácidos graxos voláteis abaixo de $200 \mathrm{mg} / \mathrm{L}$.

Fazendo uma comparação com a literatura pesquisada, o sistema obteve médias próximas ao sistema de Domingues (2005), composto por Filtro Anaeróbio (FA) seguido de Biofiltro Aerado Submerso (BAS), no qual o $\mathrm{pH}$ em média foi de 7,3 para o esgoto bruto, 7,3 para o FA e 7,5 para o BAS. O sistema de Foco (2010), composto por Filtro Anaeróbio (FA) seguido de Biofiltro Aerado Submerso (BAS), durante a fase 3, apresentou valores médios de $\mathrm{pH}$ de 6,3 para o esgoto bruto, de 7,0 para o FA e 7,7 para o BAS. Já no sistema de Barbosa (2006), composto por tanque séptico (TS) seguido de Biofiltro Aerado Submerso 
(BAS), o valor médio de $\mathrm{pH}$ para a água residuária sintética foi de 6,9 , para o TS foi de 7,1 e para o BAS foi de 7,4 .

As condições de aeração para o desenvolvimento da biomassa aeróbia heterotrófica e nitrificante no BAS foram atendidas, mantendo-se sempre o OD $>2 \mathrm{mgO}_{2} / \mathrm{L}$, com OD médio de 4,5 $\mathrm{mgO}_{2} / \mathrm{L}$. Confirmou-se a anaerobiose no FAn através das medições do OD na saída do FAn, apresentando OD médio de $0,07 \mathrm{mgO}_{2} / \mathrm{L}$, conforme apresentado na Tabela 5.8 .

Tabela 5.8: Concentrações de OD no BAS e no FAn. $(\mathrm{N}=10)$.

\begin{tabular}{lcc}
\hline \multicolumn{1}{c}{ OD } & BAS & FAn \\
\hline Média & 4,5 & 0,07 \\
\hline Mínimo & 3,1 & 0,01 \\
\hline Máximo & 5,2 & 0,25 \\
\hline $\begin{array}{l}\text { Coef. de } \\
\text { Variação }\end{array}$ & 6,4 & 0,8 \\
\hline
\end{tabular}

A temperatura ótima para nitrificação, entre 25 e $35^{\circ} \mathrm{C}$, foi alcançada, favorecida pela estação do ano em que o sistema operou, uma vez que o sistema operou em temperatura ambiente sem qualquer tipo de controle de temperatura do efluente dentro dos filtros. Os valores de $\mathrm{pH}$ no afluente ao BAS, em três medições $\left(69^{\circ}, 77^{\circ}\right.$, e $113^{\circ}$ dia) estiveram abaixo (entre 7,1 e 7,2) da faixa em que a nitrificação é constante, entre 7,2 e 8,0, mas dentro da faixa considerada ideal para a atividade dos microrganismos nitrificantes, entre 7,0 e 9,0 .

\subsection{2 - Demanda Química de Oxigênio (DQO)}

As análises de DQO bruta, para medir a eficiência do sistema, eram sempre realizadas após um dia de operação com a ARS que havia sido trocada, ou seja, nunca era feito com a ARS “fresca", e sim após o segundo dia de operação com este afluente. 
Variações significativas das concentrações desses parâmetros na água residuária sintética podem ter ocorrido em função de problemas de amostragem e análise e/ou devido às variações que a ARS sofreu enquanto armazenada. A Tabela 5.9 apresenta os resultados das concentrações de DQO bruta nos seis pontos coletados. As concentrações médias foram de $598 \mathrm{mg} / \mathrm{L}$ na ARS, $138 \mathrm{mg} / \mathrm{L}$ no efluente do FAn, $170 \mathrm{mg} / \mathrm{L}$ no Dec 1, $141 \mathrm{mg} / \mathrm{L}$ no afluente ao BAS, $48 \mathrm{mg} / \mathrm{L}$ no efluente do BAS e $30 \mathrm{mg} / \mathrm{L}$ no efluente final.

Tabela 5.9: Resultados das concentrações de DQO nos seis pontos coletados. $(\mathrm{N}=13)$

\section{DQO (mg/L)}

\begin{tabular}{lcccccc}
\hline & ARS & FAN-E & DEC 1 & BAS-A & BAS-E & FINAL \\
\hline Média & 598 & 138 & 170 & 141 & 48 & 30 \\
\hline Mínimo & 350 & 51,5 & 83,5 & 70 & 13 & 7 \\
\hline Máximo & 927,5 & 245 & 341,5 & 256 & 113 & 110 \\
\hline Coef. Var & 0,28 & 0,40 & 0,46 & 0,40 & 0,66 & 0,85 \\
\hline
\end{tabular}

A apresentação dos resultados de DQO foi dividida entre as análises do FAn, diferença entre as concentrações obtidas do afluente e do efluente do FAn (pontos de coleta: A - B); do Dec 1, diferença entre as concentrações obtidas do afluente e efluente do Dec 1 (pontos de coleta: B-C); do BAS, diferença entre as concentrações obtidas do afluente e o efluente do BAS (pontos de coleta: D - E); e do sistema Global, diferença entre as concentrações obtidas da ARS e efluente final (pontos de coleta: A - F).

Entre os dias $63^{\circ}$ e $70^{\circ}$, o sistema operou com baixas cargas, ocasionadas pela falta de reagente para a produção de ARS nas características pré-estabelecidas, possibilitando a continuidade da operação, evitando a parada na alimentação do sistema. Consequentemente observou-se nesse período uma leve queda na eficiência do sistema global, porém o FAn manteve-se operando com $70 \%$ de eficiência.

Nas Figura 5.3, Figura 5.4, Figura 5.5 e Figura 5.7, observa-se que houve variação na frequência das análises de monitoramento, entre os dias 63 e o 90, decorrente da falta e atraso ocorrido na entrega de reagentes para realizar estas análises. 
Observa-se na Figura 5.3, onde estão apresentadas as concentrações de DQO bruta obtidas do afluente e efluente do FAn, que a eficiência de remoção de DQO média foi de $74 \%$, sistema FAn foi condizente com as cargas a que ele foi submetido ao longo da operação.

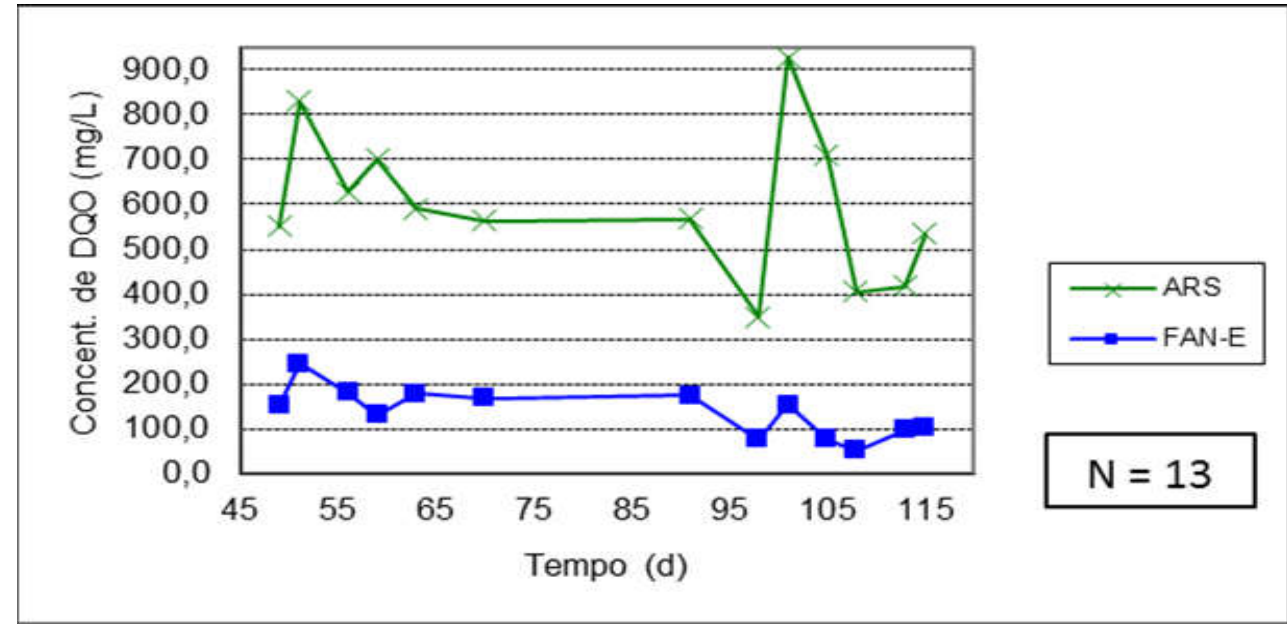

Figura 5.3: Concentrações de DQO bruta obtidas no afluente e efluente do FAn.

Na Figura 5.4, observam-se as concentrações de DQO obtidas na entrada (BAS-A) e saída do BAS (BAS-E). Pode-se afirmar que, de modo geral, a eficiência média de remoção de DQO foi de $68 \%$, condizente com as cargas a que ele foi submetido.

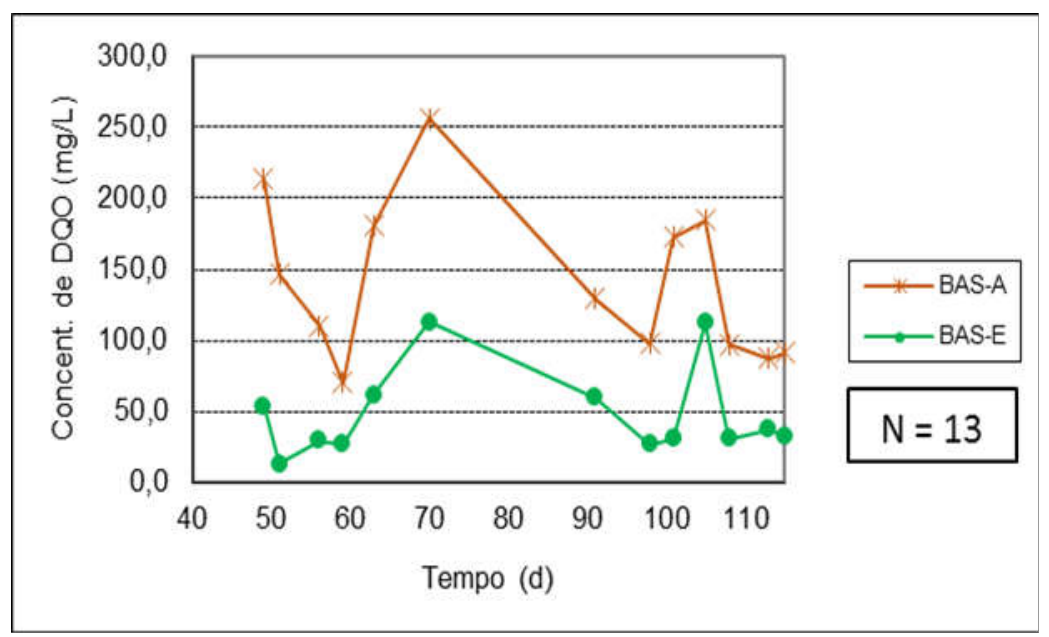

Figura 5.4: Concentrações de DQO bruta obtidas no afluente (BAS-A) e efluente (BAS-E) do BAS. 
O sistema quando analisado de modo global, segundo a Figura 5.5, demonstrou uma excelente eficiência, com remoção média de DQO de 93\%, quando comparado ao sistema FAn isoladamente, obtendo concentração média de $30 \mathrm{mg} / \mathrm{L}$, enquanto o FAn obteve concentração média de $138 \mathrm{mg} / \mathrm{L}$.

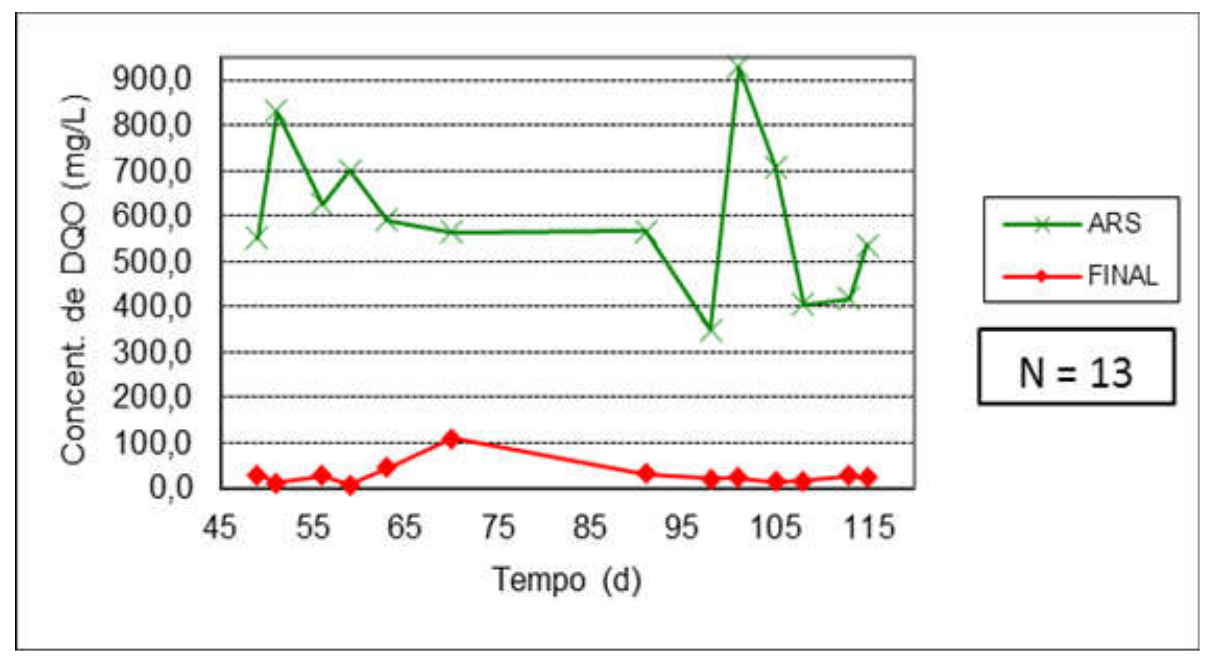

Figura 5.5: Concentrações de DQO bruta obtidas no sistema combinado FAn-BAS.

A Figura 5.6 apresenta o Gráfico box-plot da DQO, demonstrando que, no afluente (ARS), $50 \%$ dos dados estão abaixo de $568 \mathrm{mg} / \mathrm{L}$ (valor da mediana). Na saída do FAn (FAn-E), 90\% dos resultados apresentaram concentrações abaixo de $190 \mathrm{mg} / \mathrm{L}$ e a mediana é 152 $\mathrm{mg} / \mathrm{L}$. No Dec 1, 50\% dos dados estão entre 129 e $205 \mathrm{mg} / \mathrm{L}$ e que a mediana é $148 \mathrm{mg} / \mathrm{L}$. Na entrada do BAS (BAS-A), 50\% dos dados estão entre 97 e $181 \mathrm{mg} / \mathrm{L}$ e a mediana é 129 mg/L. Na saída do BAS (BAS-E), 90\% dos dados obtidos estão abaixo de $100 \mathrm{mg} / \mathrm{L}$ e o valor da mediana é $33 \mathrm{mg} / \mathrm{L}$ e no efluente Final, 50\% dos dados estão entre 17 e $30 \mathrm{mg} / \mathrm{L}$ e a mediana é $24 \mathrm{mg} / \mathrm{L}$. Observa-se que no Dec 1 houve uma elevação das concentrações quando comparadas ao efluente do FAn, situação está justificada pelo baixo desempenho obtido por esta unidade, durante toda a operação, em termos de ST e SST. 


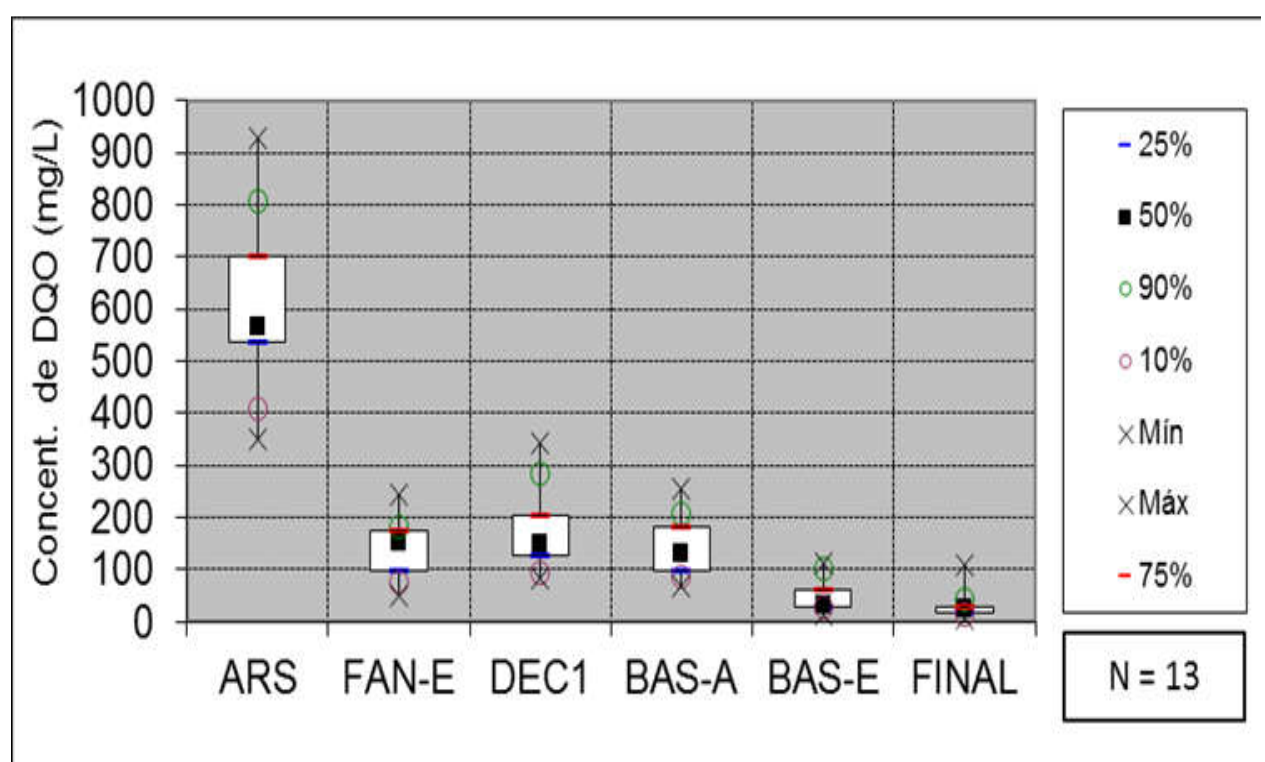

Figura 5.6: Box-plot das concentrações de DQO bruta.

Já na Figura 5.7, são apresentadas as eficiências do FAn e BAS isoladamente e do sistema combinado, podendo observar que o FAn manteve desempenho constante, de modo geral, quanto à eficiência, removendo DQO em média com eficiência de $77 \%$ e eficiência máxima de $89 \%$. Já o BAS funcionou como uma etapa de polimento ao tratamento, uma vez que, quando aumentou a eficiência do FAn, baixou a eficiência do BAS, o qual obteve uma eficiência média de $66 \%$ e máxima de $91 \%$.

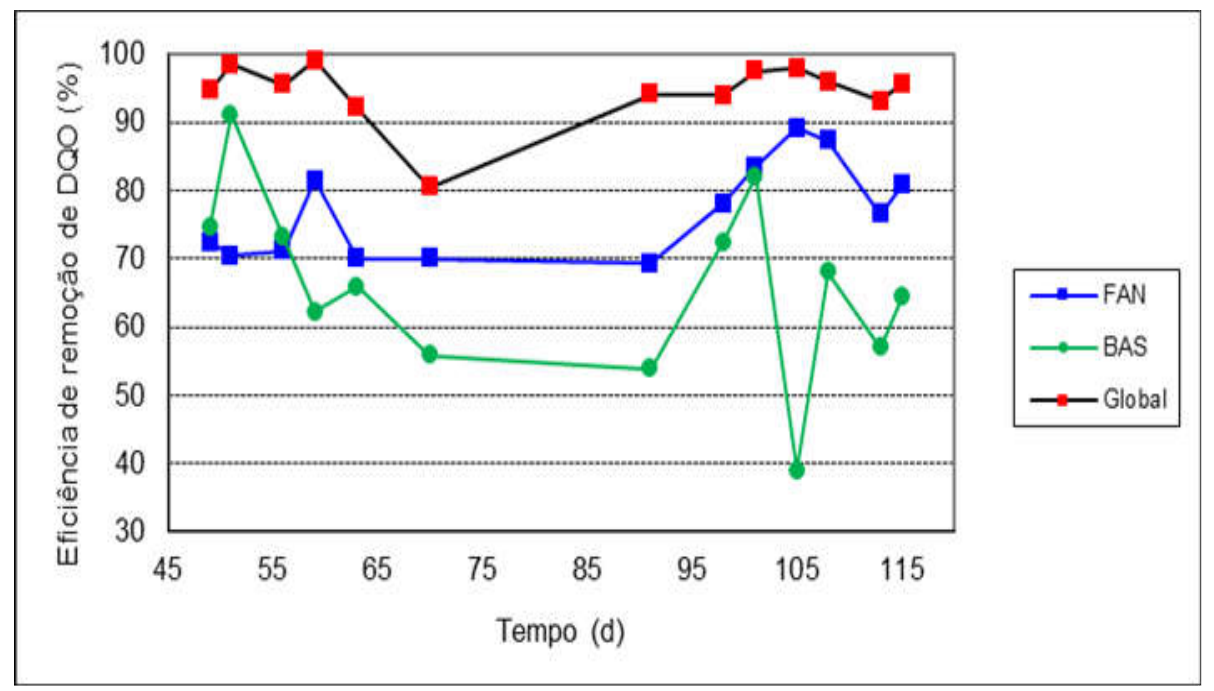

Figura 5.7: Eficiências de DQO bruta nos efluentes de cada filtro, e do sistema combinado, durante o monitoramento após a partida. 
O sistema combinado apresentou excelente desempenho, mantendo a eficiência, de modo geral, acima de $90 \%$, com baixa apenas no período em que o sistema operou com baixas cargas, contudo a eficiência global não apresentou valores inferiores a $80 \%$. O Sistema combinado operou com eficiência média de 94\%.

A Figura 5.8 apresenta o Gráfico box-plot da DQO, demonstrando que, no FAn, $50 \%$ dos dados estão entre 70 e $80 \%$ e que a mediana é $77 \%$. No BAS, $50 \%$ dos dados estão entre 60 e $70 \%$ e a mediana é $66 \%$ e no sistema combinado, 50\% dos dados estão entre 90 e 100 \% e a mediana é 96\%. É possível observar que o BAS sofreu mais variações de eficiência, e o sistema combinado manteve-se constante, comparado ao FAn e ao BAS, isoladamente.

Fazendo uma comparação com a literatura pesquisada, o sistema estudado obteve uma eficiência global elevada, uma vez que o sistema de Barbosa (2006), TS+BAS, obteve eficiência média de $89,8 \%$ e máxima de 95,8\%. O sistema de Domingues (2005), FA+BAS, obteve eficiência média de $87 \%$ e máxima de $95 \%$. Segundo Gonçalves et al (2001), as eficiências de remoção esperadas para sistemas combinados anaeróbio-aeróbio, são de 80 a $90 \%$ de DQO.

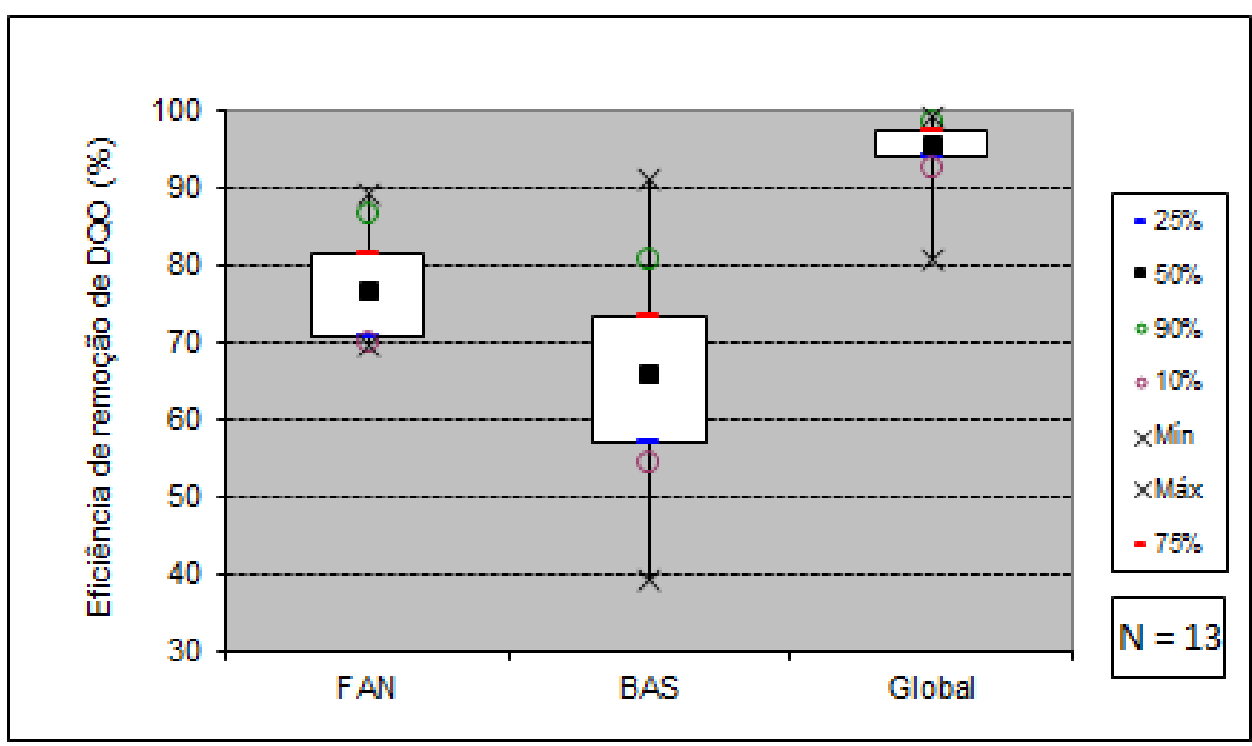

Figura 5.8: Box-plot do resultado da eficiência de DQO bruta. 


\subsection{3 - Demanda Bioquímica de Oxigênio $\left(\mathrm{DBO}_{5}\right)$}

As análises de $\mathrm{DBO}_{5}$ foram realizadas com menor frequência, devido a ser este um exame mais demorado, obtendo assim um conjunto de dados menor. As concentrações de DBO no efluente do BAS não sofreram grandes variações, com concentração média de $14 \mathrm{mg} / \mathrm{L}$, e desvio padrão de 3,0 mg/L. A ARS apresentou grandes variações, as mesmas oscilações observadas nas concentrações de DQO.

A Tabela 5.10 apresenta os resultados das concentrações de DBO das sete análises nos seis pontos coletados. As concentrações médias foram de $406 \mathrm{mg} / \mathrm{L}$ na ARS, $71 \mathrm{mg} / \mathrm{L}$ no efluente do FAn, $90 \mathrm{mg} / \mathrm{L}$ no Dec 1, $37 \mathrm{mg} / \mathrm{L}$ no afluente ao BAS, $14 \mathrm{mg} / \mathrm{L}$ no efluente do BAS e $12 \mathrm{mg} / \mathrm{L}$ no efluente final.

Tabela 5.10: Resultados das concentrações de $\mathrm{DBO}_{5}$ nos seis pontos coletados. $(\mathrm{N}=7)$

\begin{tabular}{lccccccc}
\hline \multicolumn{7}{c}{ DBO $_{5}$} \\
& Afluente & FAN-S & DEC 1 & BAS-E & BAS-S & FINAL \\
\hline Média & 406 & 71 & 90 & 37 & 14 & 12 \\
\hline Mínimo & 328 & 45 & 52 & 18 & 9 & 8 \\
\hline Máximo & 488 & 149 & 224 & 74 & 18 & 17 \\
\hline Coef. Var & 0,12 & 0,53 & 0,68 & 0,56 & 0,21 & 0,25 \\
\hline
\end{tabular}

A Figura 5.9 apresenta os resultados da concentração de DBO obtidas no efluente do FAn e do BAS, assim como no efluente final. A concentração mediana de DBO obtida na ARS foi de $412 \mathrm{mg} / \mathrm{L}$. O efluente do FAn apresentou valores de DBO mediana de $57 \mathrm{mg} / \mathrm{L}$, porém uma concentração elevada, acima do padrão do lançamento de efluentes, no $56^{\circ}$ dia de operação. No efluente do BAS, a concentração mediana de $15 \mathrm{mg} / \mathrm{L}$ e no efluente final mediana foi de $12 \mathrm{mg} / \mathrm{L}$. 


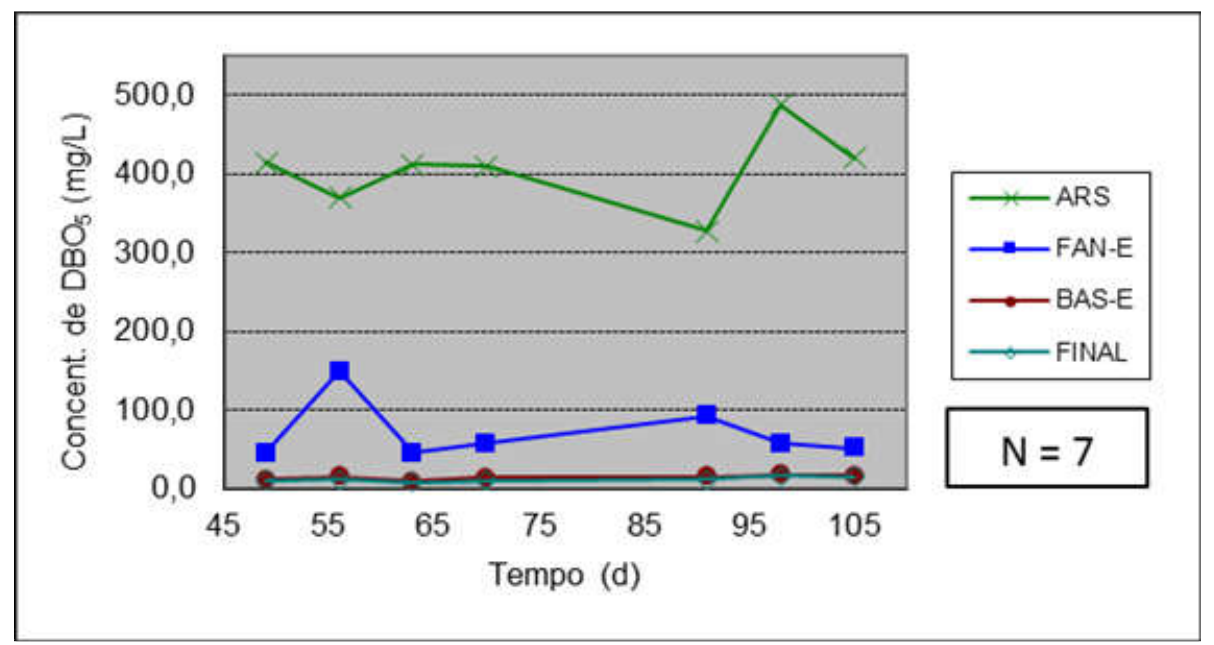

Figura 5.9: Perfil de variação (Comportamento da DBO).

A Figura 5.10 apresenta o Gráfico box-plot da DBO, demonstrando que, no afluente (ARS), 50\% dos dados estão entre 390 e $417 \mathrm{mg} / \mathrm{L}$ e que a mediana é $412 \mathrm{mg} / \mathrm{L}$. No FAn, a mediana, percentil 50, equivale a $57 \mathrm{mg} / \mathrm{L}$. Isso indica um redução de $86 \%$ da concentração de DBO que alimentou o FAn. No Dec 1, 50\% dos dados estão entre 56 e 89 $\mathrm{mg} / \mathrm{L}$ e que a mediana é $66 \mathrm{mg} / \mathrm{L}$. No afluente do BAS (BAS-E), 75\% dos dados amostrais apresentam valores abaixo de $45 \mathrm{mg} / \mathrm{L}$ e a mediana é $30 \mathrm{mg} / \mathrm{L}$. No efluente do BAS (BASS), $50 \%$ dos dados estão entre 13 e $16 \mathrm{mg} / \mathrm{L}$ e a mediana é $15 \mathrm{mg} / \mathrm{L}$ e no Efluente Final $50 \%$ dos dados estão entre 11 e $14 \mathrm{mg} / \mathrm{L}$ e a mediana é $12 \mathrm{mg} / \mathrm{L}$. No Dec 1 a elevação das concentrações decorreu pela baixa eficiência obtida por esta unidade, durante toda a operação, assim como observado nas análises de DQO e SST.

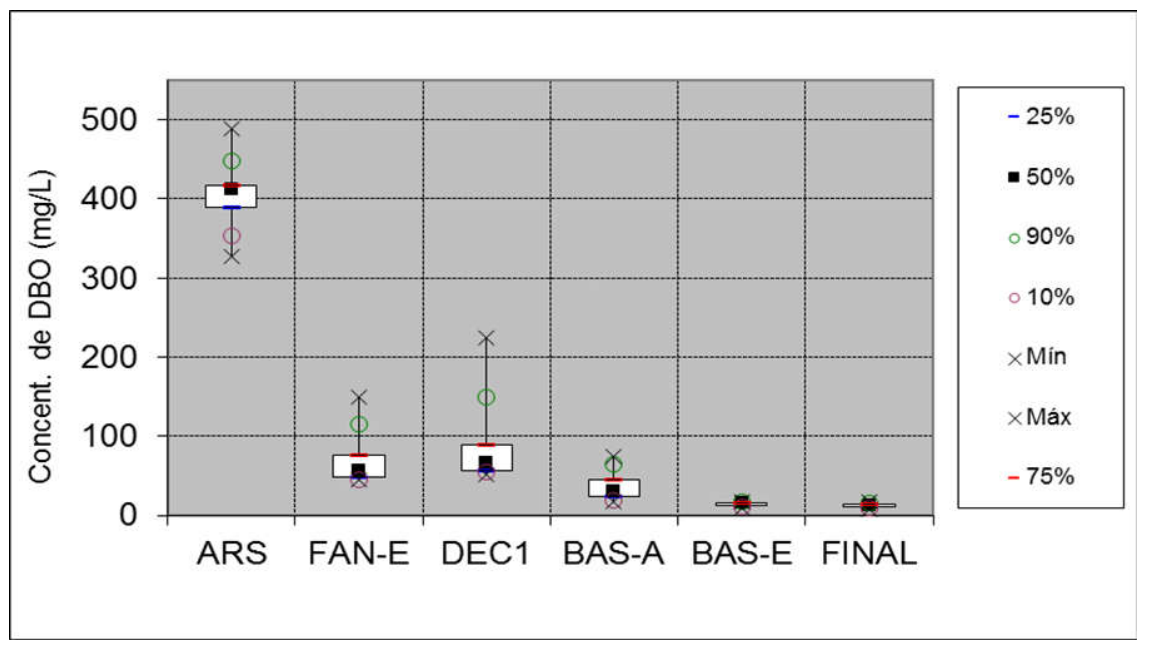

Figura 5.10: Box-Plot das concentrações de DBO. 
As eficiências obtidas na remoção de DBO estão apresentadas na Figura 5.11, em que o FAn obteve eficiência média de $82 \%$ e mediana de $88 \%$, o BAS obteve eficiência média de $54 \%$ e mediana de $53 \%$ e o sistema global obteve uma elevada eficiência, de $97 \%$ na média e mediana, com desvio padrão foi 0,7 .

Em relação a DBO, conclui-se que o sistema, quando avaliado em sistema isolado ou combinado, atendeu ao padrão de lançamento de efluentes de Sistemas de Tratamento de Esgotos Sanitários (CONAMA 430/2011), na esfera federal, que o limita a uma concentração máxima de $120 \mathrm{mg} / \mathrm{L}$ de $\mathrm{DBO}_{5}$ ou eficiência de remoção de $60 \%$ de DBO.

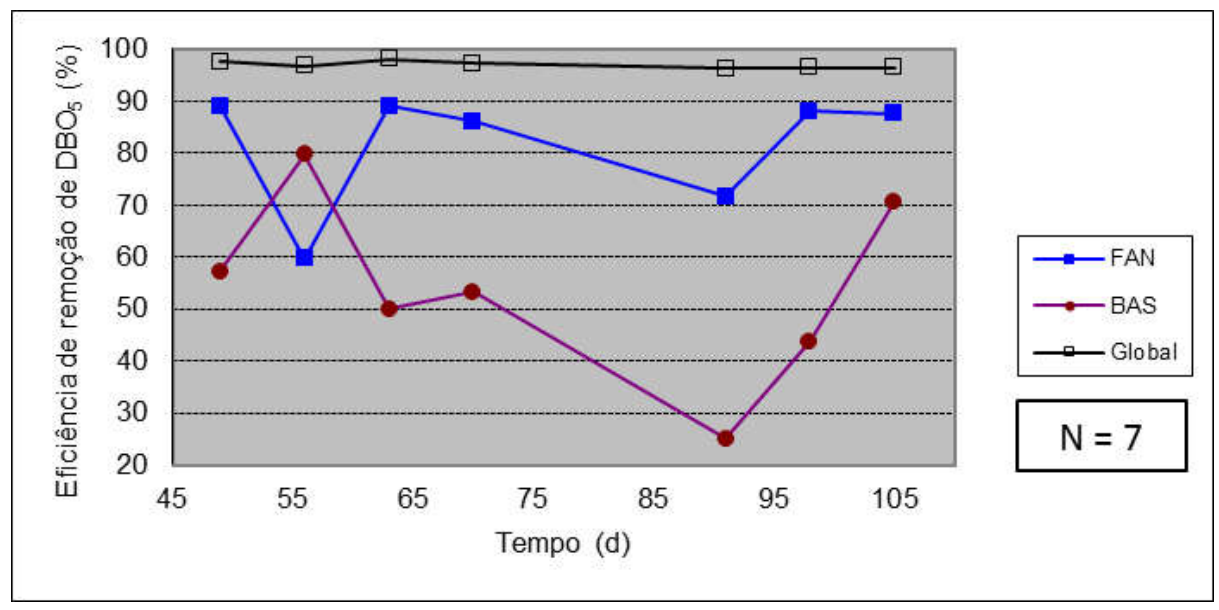

Figura 5.11: Eficiências de DBO.

A Figura 5.12 apresenta o Gráfico box-plot obtido com as eficiências de remoção de DBO, demonstrando que, no FAn, $50 \%$ dos dados estão entre 79 e $89 \%$ e que a mediana é $88 \%$. No BAS, $50 \%$ dos dados estão entre 47 e $64 \%$ e a mediana é $53 \%$ e no sistema combinado, $50 \%$ dos dados estão entre 96 e $97 \%$ e a mediana é 97\%. Considerando-se os padrões de lançamento da NBR 13969/97, que é mais restritiva (DBO máxima de 30 mg/L), o sistema FAn não atendeu às exigências, já o BAS e o sistema combinado atenderam em 100 \% a exigência para lançamento.

Quando comparado a outros sistemas pesquisados na literatura, conclui-se que este tipo de sistema combinado apresentou uma eficiência média elevada de 97\% e máxima de $98,1 \%$ de remoção de DBO, enquanto que Barbosa (2006) obteve eficiência média de 90,4\% e 
máxima de 97,2\%. O sistema de Domingues (2005) obteve eficiência média de 91\% e máxima de 95\%. O sistema de Foco (2010) obteve eficiência média de 97\%. Segundo Gonçalves et al (2001), as eficiências de remoção esperadas para sistemas combinados anaeróbio-aeróbio, são de 85 a 95\% de DBO.

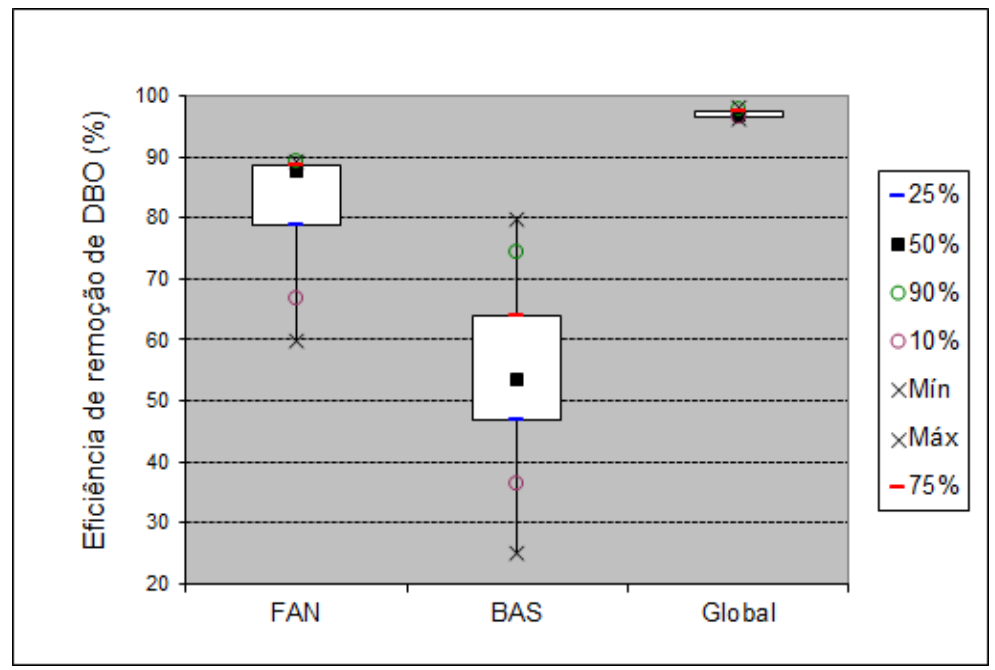

Figura 5.12: Box-Plot do resultado das eficiências de DBO.

\subsection{4 - Série de Sólidos (ST, STV, STF, SST)}

Os resultados da série de sólidos, Sólidos Totais (ST), Sólidos Totais Voláteis (STV), Sólidos Totais Fixos (STF) e Sólidos Suspensos Totais (SST), serão apresentados nos itens seguintes.

\subsubsection{1 - Sólidos Totais (ST)}

A Tabela 5.11 apresenta os resultados dos ST das dez análises nos seis pontos coletados. Assim, as concentrações médias foram de $1229 \mathrm{mg} / \mathrm{L}$ na ARS, $957 \mathrm{mg} / \mathrm{L}$ no efluente do FAn, 994 mg/L no Dec 1, 1063 mg/L no afluente ao BAS, 953 mg/L no efluente do BAS e $809 \mathrm{mg} / \mathrm{L}$ efluente final.

As concentrações do ST são apresentadas graficamente em box-plot na Figura 5.13, onde pode-se observar que, no afluente (ARS), 50\% dos resultados estão entre 1108 e 1289 $\mathrm{mg} / \mathrm{L}$ e que a mediana é $1230 \mathrm{mg} / \mathrm{L}$. No efluente do FAn 50\% dos resultados estão entre 
932 e $1058 \mathrm{mg} / \mathrm{L}$ e mediana é $1003 \mathrm{mg} / \mathrm{L}$. No efluente do BAS, 50\% dos resultados estão entre 963 e $1052 \mathrm{mg} / \mathrm{L}$ e mediana é $1003 \mathrm{mg} / \mathrm{L}$. Já no efluente final, 50\% dos resultados estão entre 522 e 990 mg/L e a mediana é 950 mg/L.

Tabela 5.11: Resultado das concentrações de ST das dez análises nos seis pontos coletados. $(\mathrm{N}=10)$.

\begin{tabular}{ccccccc}
\hline \multicolumn{7}{c}{ Sólidos Totais (mg/L) } \\
\hline & ARS & FAn & Dec 1 & BAS-E & BAS-S & E. Final \\
\hline Média & 1229 & 957 & 994 & 1063 & 953 & 809 \\
\hline Mediana & 1230 & 1003 & 1055 & 1081 & 1003 & 950 \\
\hline Máximo & 1814 & 1273 & 1342 & 1260 & 1171 & 1114 \\
\hline Mínimo & 553 & 256 & 207 & 658 & 309 & 375 \\
\hline $\begin{array}{c}\text { Desvio } \\
\text { Padrão }\end{array}$ & 333 & 275 & 312 & 162 & 236 & 292 \\
\hline
\end{tabular}

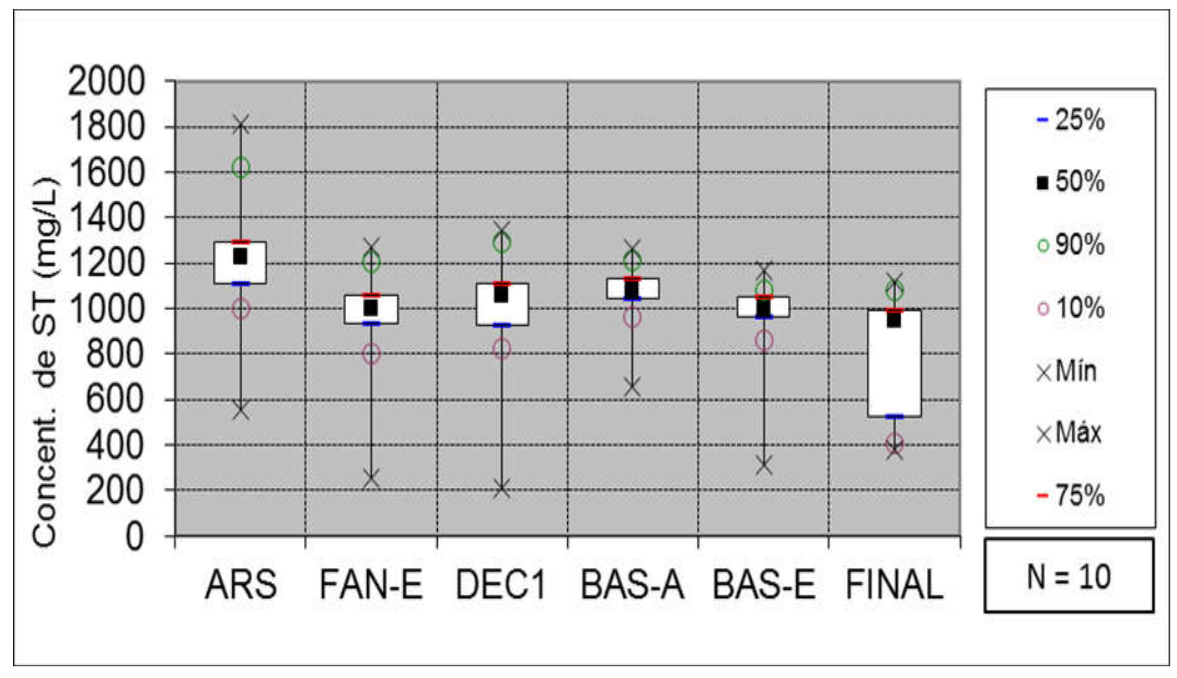

Figura 5.13: Box-Plot das concentrações de ST. 
O gráfico apresentado na Figura 5.14 mostra o comportamento do sistema global quanto as concentrações de ST, observando apenas as concentrações afluente e efluente do sistema.

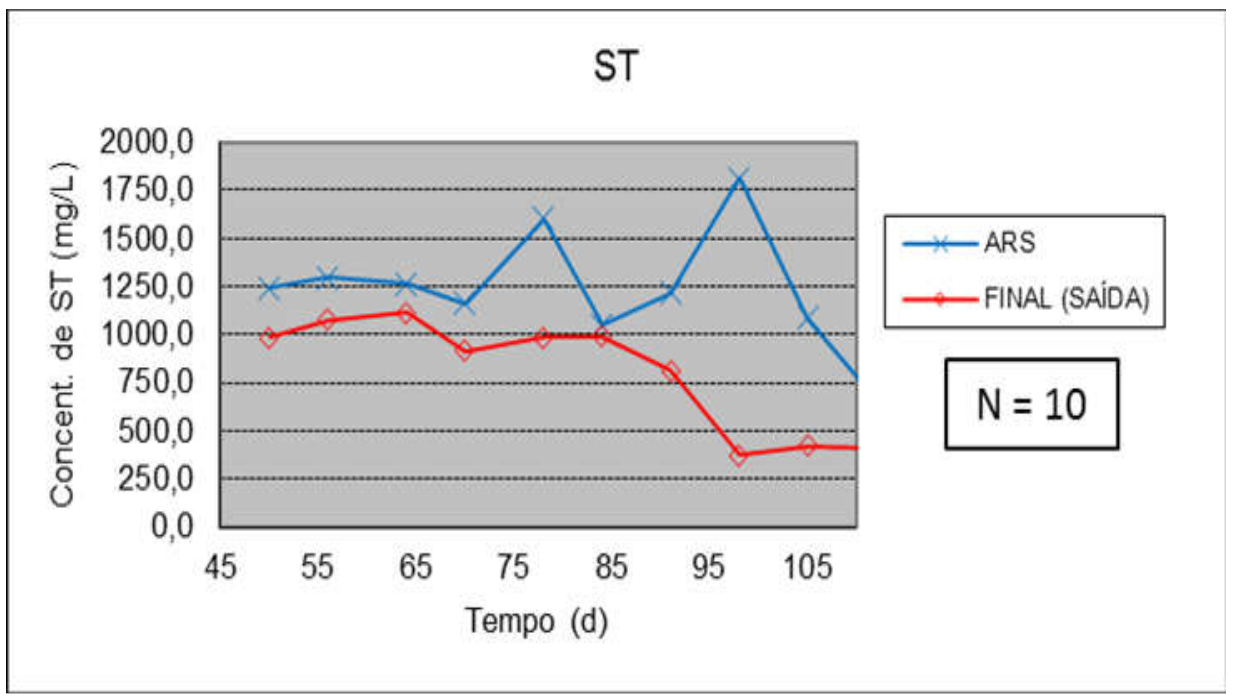

Figura 5.14: Concentrações de ST.

A eficiência global de remoção de ST do sistema combinado, como apresentada na Figura 5.15, estiveram próximas as eficiências do FAn, analisado isoladamente, porém a partir do $90^{\circ}$ dia, apresentou eficiências melhores. A eficiência global teve média de 31,5\%,22\% para o FAn e 12\% para o BAS, como pode-se ver na Figura 5.16.

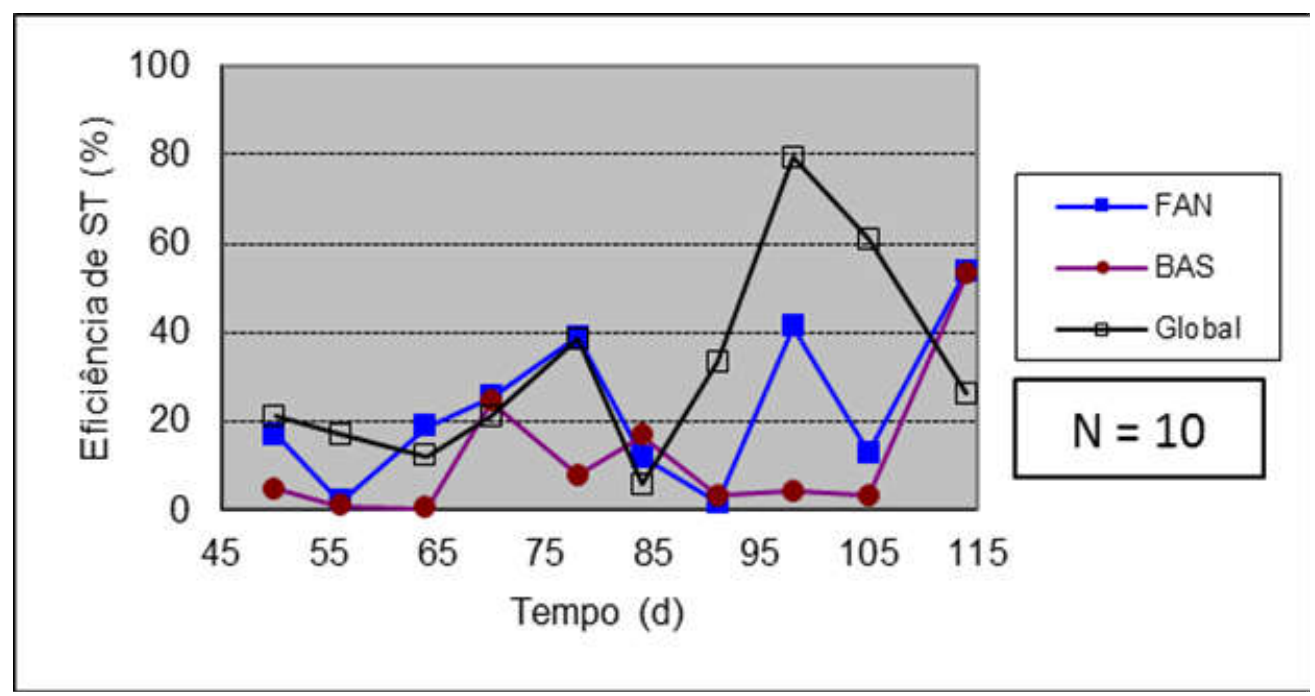

Figura 5.15: Gráfico de eficiência de remoção de ST 


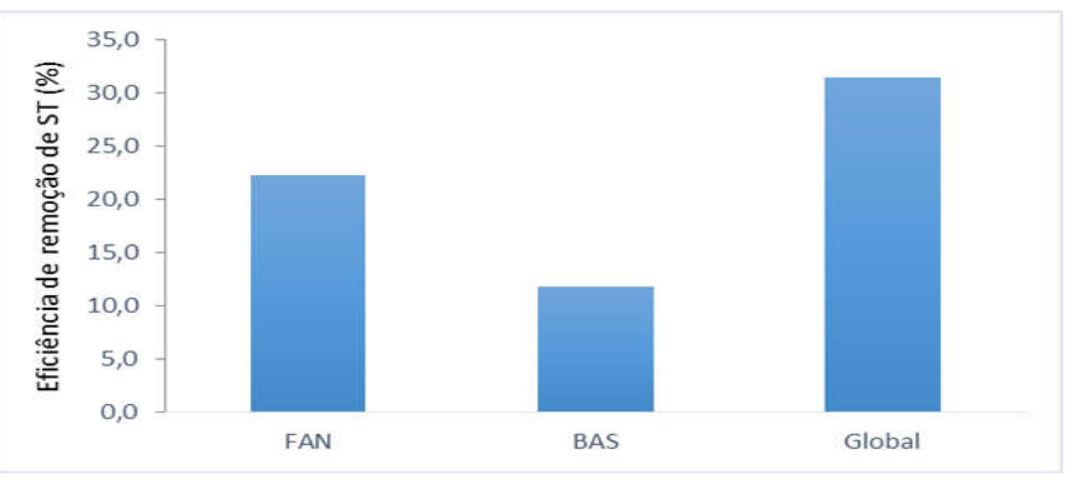

Figura 5.16: Gráfico comparativo das eficiências de remoção de ST do sistema. (N=10)

O Gráfico Box-plot na Figura 5.17, apresenta ainda a variação e mediana obtida em relação as eficiências de ST, onde 50\% dos resultados do efluente FAn estão entre 12 e $36 \%$ e a mediana é 18\%, no efluente BAS 50\% dos resultados do efluente FAn estão entre 3 e 14\% e a mediana é $4 \%$, já no sistema combinado $50 \%$ dos resultados obtidos estão entre 18 e $37 \%$ e a mediana é $24 \%$.

Avaliando o sistema global, com eficiência de remoção de ST de 31,5\%, obteve-se eficiência elevada, se comparada à pesquisa de Araújo e Freitas (2014), que obteve eficiência média de $6 \%$, utilizando água residuária sintética e o mesmo meio suporte, em um sistema combinado UASB+BAS. Mas obteve eficiência média baixa se comparada ao sistema utilizado por Achaval (2014), que obteve 47\% de remoção para ST, utilizando esgoto doméstico unifamiliar e realizando tratamento em sistema anaeróbio.

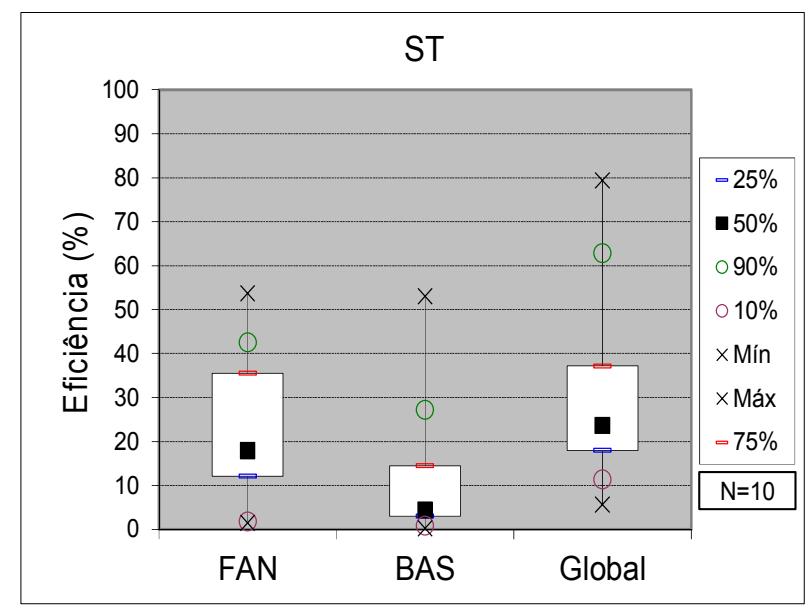

Figura 5.17: Box-plot das eficiências de remoção de ST. 


\subsubsection{2 - Sólidos Totais Fixos (STF)}

A Tabela 5.12 apresenta os resultados para STF nos seis pontos coletados. Foram obtidas concentrações médias de $393 \mathrm{mg} / \mathrm{L}$ na ARS, $230 \mathrm{mg} / \mathrm{L}$ no efluente do FAn, $198 \mathrm{mg} / \mathrm{L}$ no Dec 1, $200 \mathrm{mg} / \mathrm{L}$ no afluente ao BAS, $260 \mathrm{mg} / \mathrm{L}$ no efluente do BAS e $220 \mathrm{mg} / \mathrm{L}$ efluente final.

A maior concentração de STF observada no BAS justifica-se pelos sólidos fixos representarem a matéria inorgânica, substâncias minerais dissolvidas, que não são usualmente removidas, mas com pouca influência, por ser um material inerte. Porém, quando em excesso, isso aumenta as possibilidades de entupimento e saturação dos filtros.

Tabela 5.12: Resultado das concentrações de STF. $(\mathrm{N}=10)$.

\begin{tabular}{cccccccc}
\hline \multicolumn{7}{c}{ Sólidos Totais Fixos (mg/L) } \\
\hline & ARS & FAn & Dec 1 & BAS-E & BAS-S & E. Final \\
\hline Média & 393 & 230 & 198 & 200 & 260 & 220 \\
\hline Mediana & 373 & 205 & 155 & 162 & 252 & 221 \\
\hline Máximo & 898 & 453 & 537 & 457 & 438 & 303 \\
\hline Mínimo & 208 & 103 & 54 & 103 & 121 & 95 \\
\hline Desvio Padrão & 193 & 122 & 139 & 103 & 87 & 68 \\
\hline
\end{tabular}

As concentrações do STF são apresentadas graficamente em box-plot na Figura 5.18, em que se observa em 50\% dos resultados do afluente (ARS) concentrações entre 279 e 410 $\mathrm{mg} / \mathrm{L}$ e que a mediana é $373 \mathrm{mg} / \mathrm{L}$. No efluente do FAn, 50\% dos resultados estão entre 155 e $240 \mathrm{mg} / \mathrm{L}$ e mediana é $205 \mathrm{mg} / \mathrm{L}$. No efluente do BAS, 50\% dos resultados estão entre 226 e $304 \mathrm{mg} / \mathrm{L}$ e mediana é $252 \mathrm{mg} / \mathrm{L}$. Já no efluente final, 50\% dos resultados estão entre 208 e $266 \mathrm{mg} / \mathrm{L}$ e a mediana é $221 \mathrm{mg} / \mathrm{L}$. 


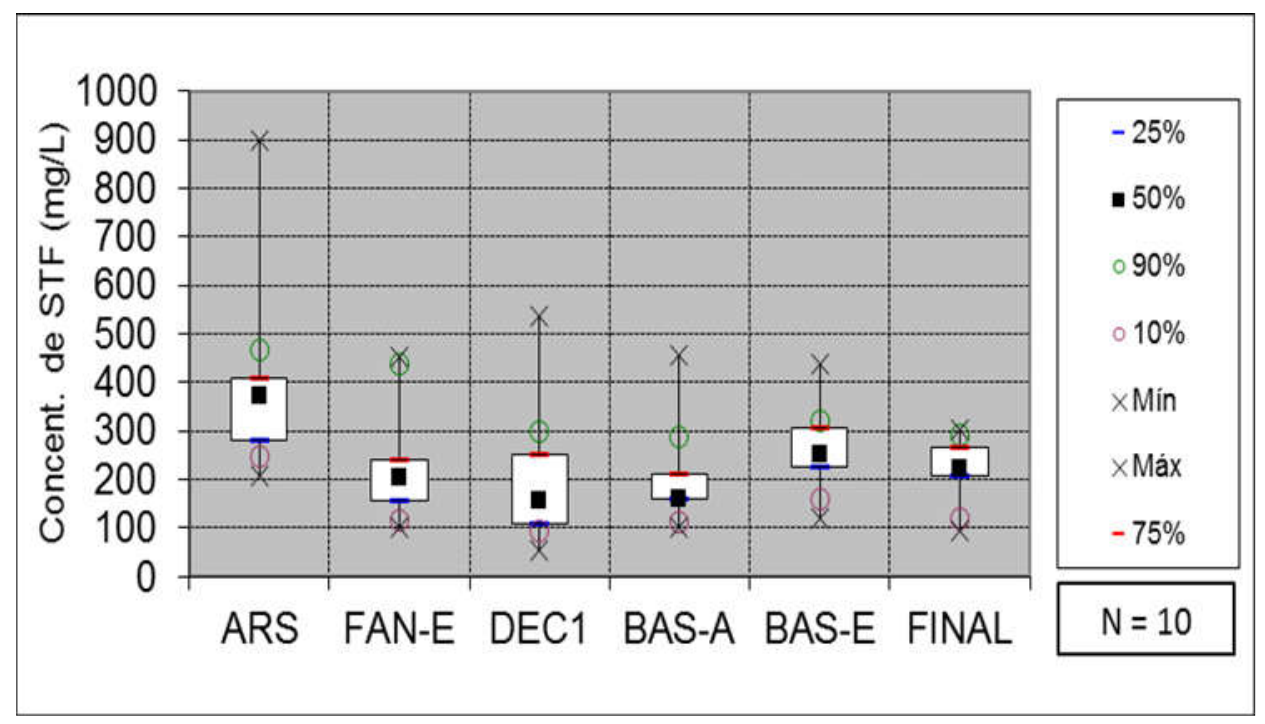

Figura 5.18: Gráfico Box-plot das concentrações de STF

A eficiência média global de remoção dos STF do sistema combinado, como apresentada na Figura 5.19, esteve próxima a eficiência média do FAn, quando analisado isoladamente. As eficiências apresentadas na Figura 5.20, obtiveram média de 38\% para o sistema combinando, $36 \%$ para o FAn e de - $49 \%$ para o efluente do BAS.

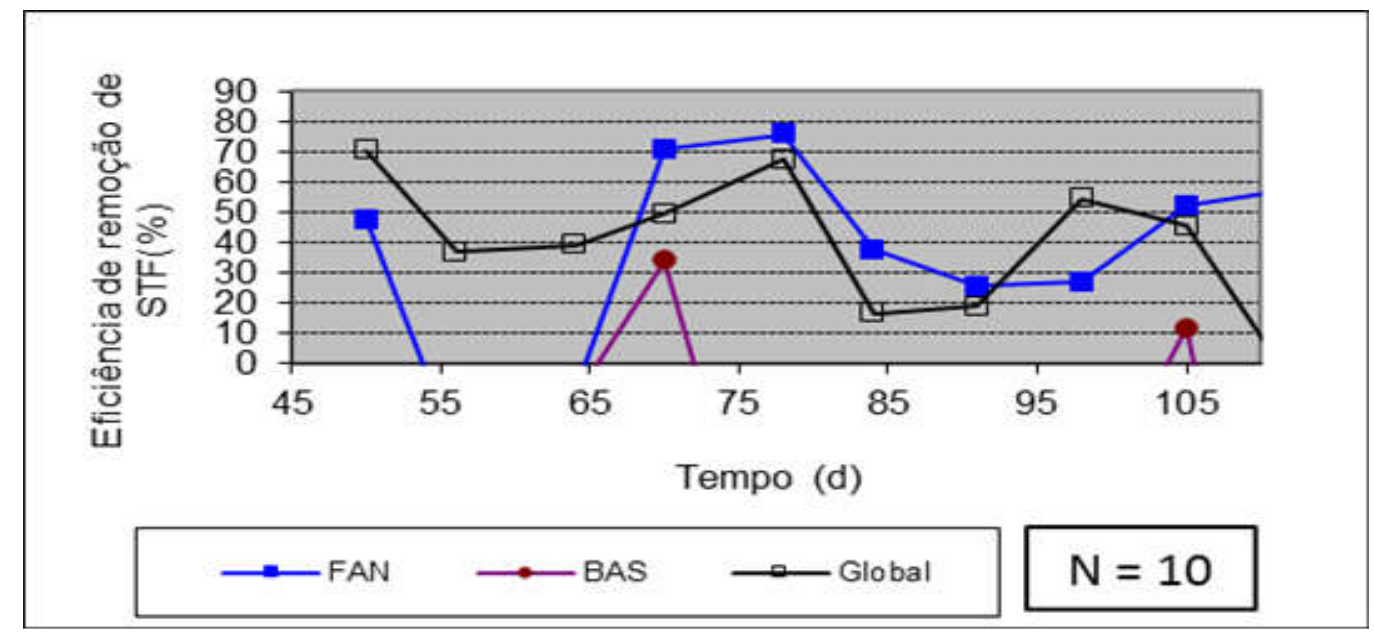

Figura 5.19: Gráfico comparativo das eficiências obtidas ao longo do sistema. 


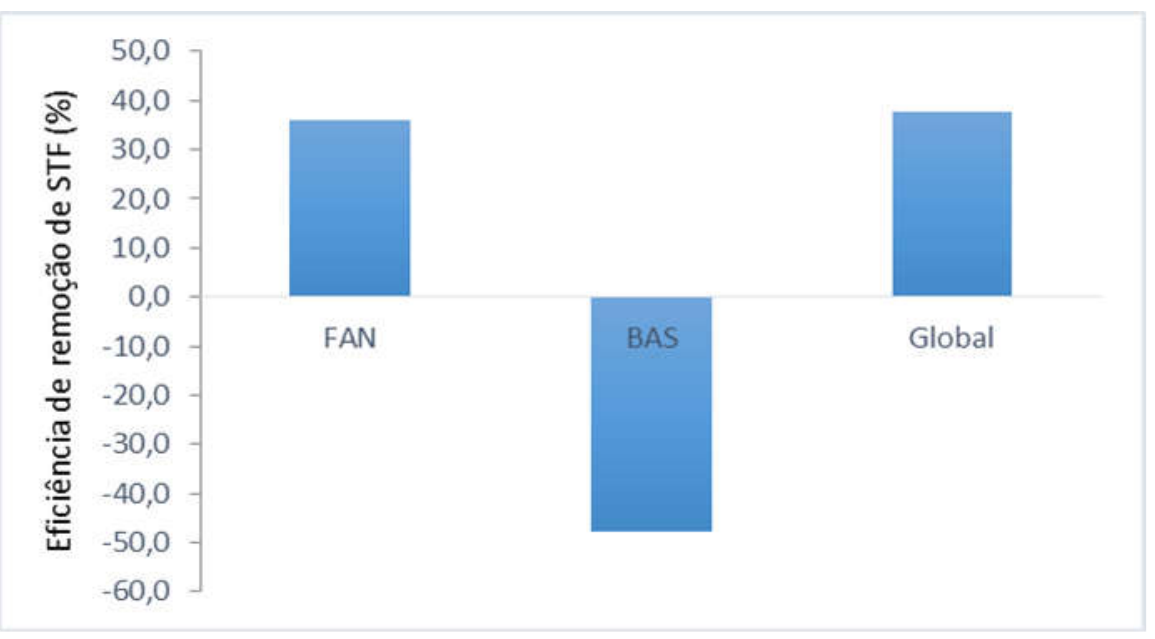

Figura 5.20: Gráfico comparativo das eficiências de remoção de STF. $(\mathrm{N}=10)$.

Na Figura 5.21 estão apresentados, em Gráfico box-plot, os dados obtidos referentes a eficiência remoção de STF, onde 50\% dos resultados do efluente FAn estão entre 26 e $57 \%$ e a mediana é $43 \%$, no efluente BAS $50 \%$ dos resultados estão entre - 85 e - 3\% e a mediana é - 32\%, já no sistema combinado $50 \%$ dos resultados obtidos estão entre 23 e $53 \%$ e a mediana é $42 \%$. No BAS não houve remoção de STF, o que resultou em eficiências de remoção de STF negativa.

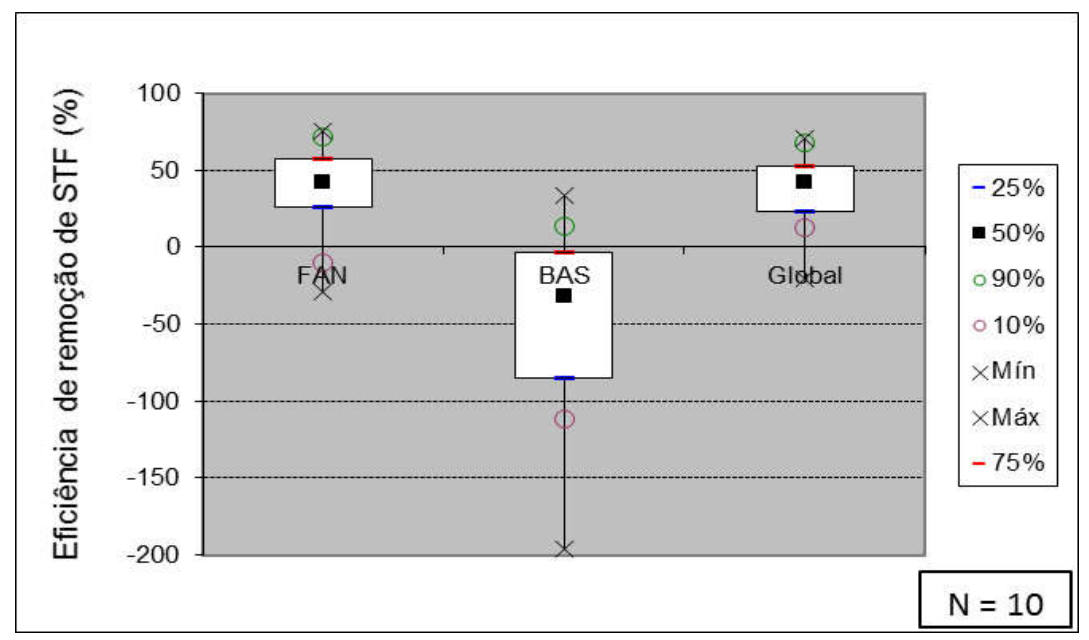

Figura 5.21: Box-plot das eficiências de remoção de STF 


\subsubsection{3 - Sólidos Totais Voláteis (STV)}

Os resultados para STV, nos seis pontos coletados, estão apresentados na Tabela 5.13. Pode-se observar que o sistema obteve concentrações médias de $836 \mathrm{mg} / \mathrm{L}$ para ARS, 727 $\mathrm{mg} / \mathrm{L}$ para o efluente do FAn, $784 \mathrm{mg} / \mathrm{L}$ no Dec 1, $863 \mathrm{mg} / \mathrm{L}$ no afluente ao BAS, 693 $\mathrm{mg} / \mathrm{L}$ para o efluente do BAS, e $589 \mathrm{mg} / \mathrm{L}$ efluente final. Na Figura 5.22 está apresentado o gráfico Box-plot das concentrações de STV.

Tabela 5.13: Resultado das concentrações de STV. $(\mathrm{N}=10)$.

\begin{tabular}{cccccccc}
\hline & \multicolumn{7}{c}{ Sólidos Totais Voláteis (mg/L) } \\
\hline & ARS & FAn & Dec 1 & BAS-E & BAS-S & E. Final \\
\hline Média & 836 & 727 & 784 & 863 & 693 & 589 \\
\hline Mediana & 812 & 761 & 837 & 883 & 791 & 701 \\
\hline Máximo & 1606 & 951 & 1129 & 1045 & 913 & 863 \\
\hline Mínimo & 301 & 153 & 52 & 555 & 4 & 105 \\
\hline Desvio Padrão & 324 & 226 & 293 & 128 & 265 & 291 \\
\hline
\end{tabular}

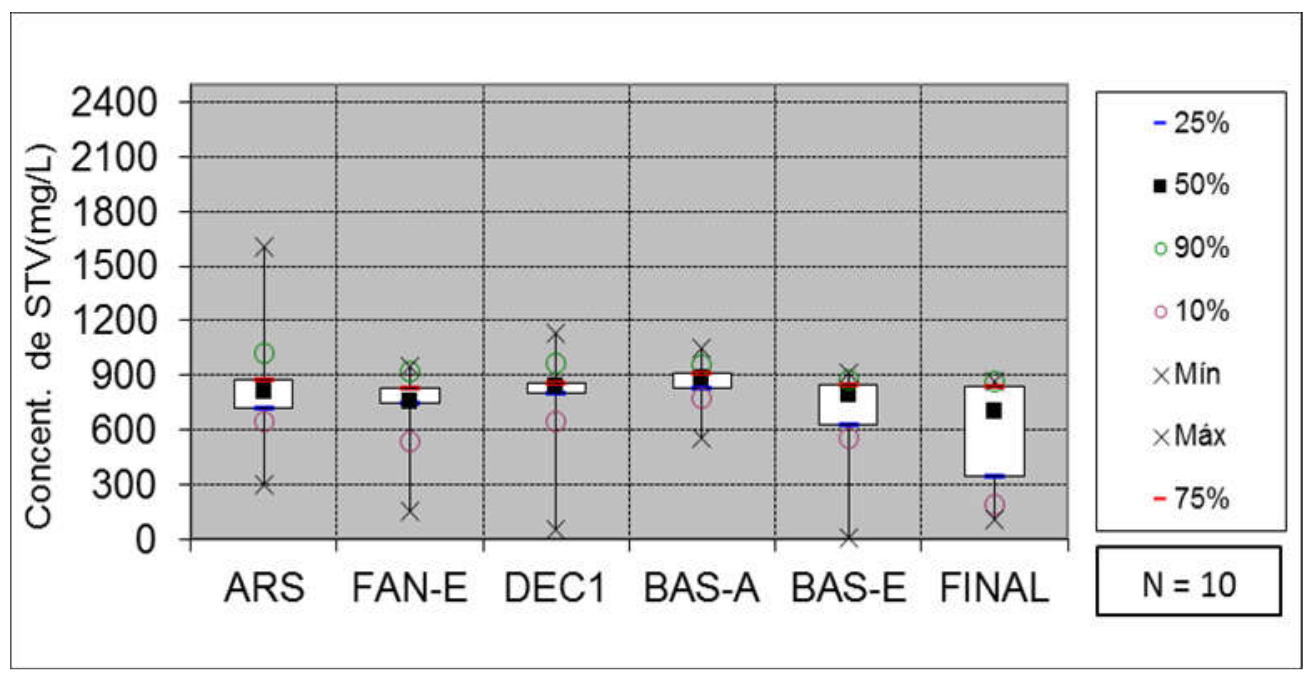

Figura 5.22: Gráfico Box-plot das concentrações de STV. 
O sistema combinado obteve melhor eficiência de remoção dos STV quando comparado a cada unidade do sistema, que obtiveram eficiências menores, como apresentado na Figura 5.23. Foram obtidas eficiências médias de $27,1 \%$ para o sistema combinado, $11,7 \%$ para o FAn e de $22,4 \%$ para o efluente do BAS. Na Figura 5.24, observa-se que, a partir do $85^{\circ}$ dia, o sistema global melhorou seu desempenho, mantendo-se superior as eficiências encontradas no FAn e BAS isolados.

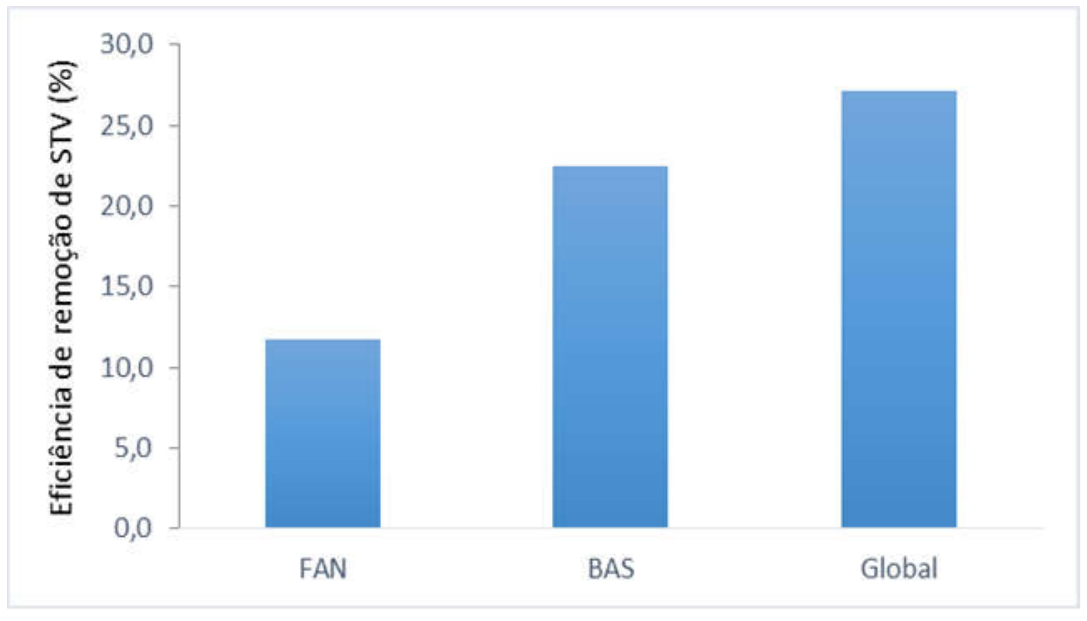

Figura 5.23: Gráfico comparativo das eficiências de remoção de STV. (N=10).

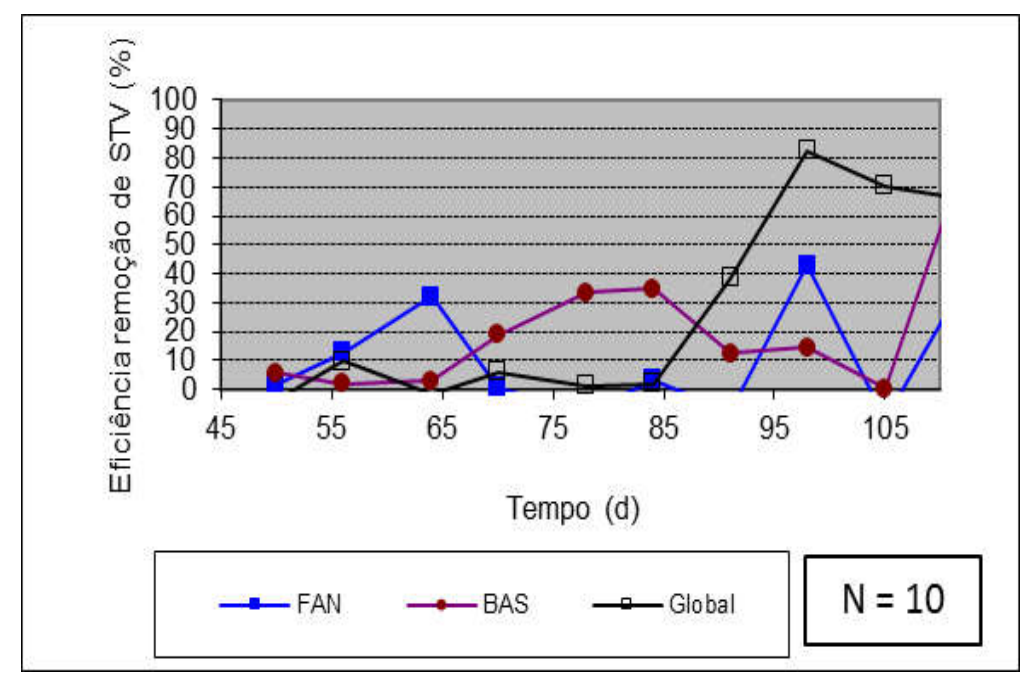

Figura 5.24: Gráfico das eficiências de remoção de STV. 
Na Figura 5.25 estão apresentados, em Gráfico box-plot, os dados obtidos referentes à eficiência remoção de STV, onde 50\% dos resultados do efluente FAn estão entre -5 e 27\% e a mediana é $3 \%$.

No efluente BAS, $50 \%$ dos resultados estão entre 4 e $30 \%$ e a mediana é $13 \%$, já no sistema combinado, $50 \%$ dos resultados obtidos estão entre 2 e $58 \%$ e a mediana é $8 \%$.

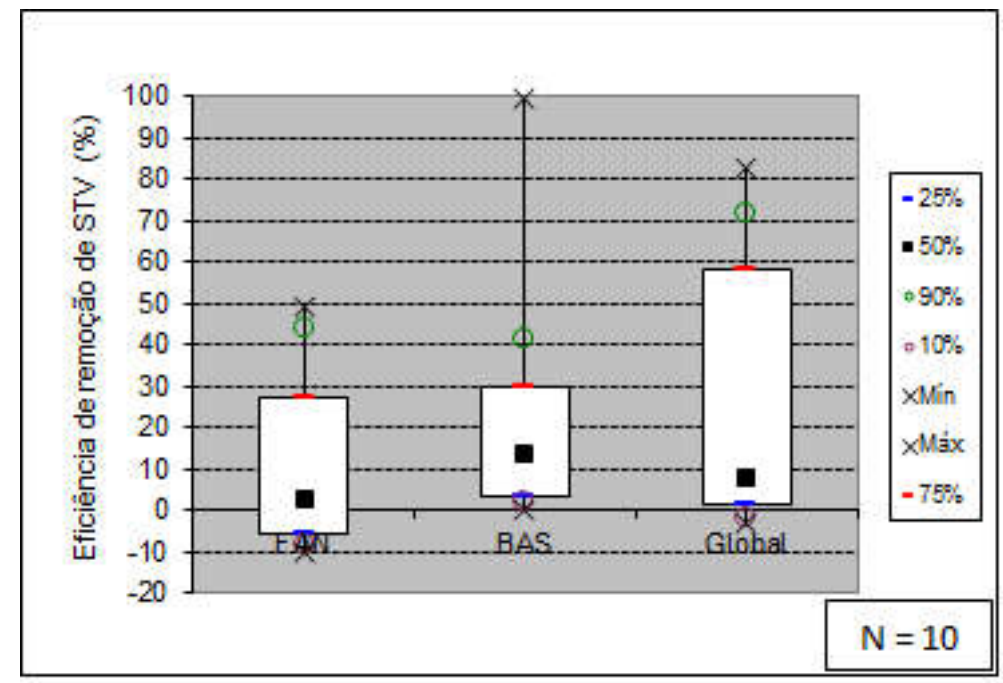

Figura 5.25: Gráfico Box-plot das eficiências de STV.

\subsubsection{4 - Sólidos Suspensos Totais (SST)}

A Tabela 5.14 apresenta os resultados obtidos para SST nos seis pontos coletados. Obtendo concentrações médias de $91 \mathrm{mg} / \mathrm{L}$ na ARS, $22 \mathrm{mg} / \mathrm{L}$ no efluente do FAn, $21 \mathrm{mg} / \mathrm{L}$ no Dec $1,25 \mathrm{mg} / \mathrm{L}$ no afluente ao BAS, $8 \mathrm{mg} / \mathrm{L}$ no efluente do BAS e $6 \mathrm{mg} / \mathrm{L}$ efluente final.

Tabela 5.14: Resultados das concentrações de SST. $(\mathrm{N}=10)$

\section{Sólidos Suspensos Totais (mg/L)}

\begin{tabular}{ccccccc}
\hline & ARS & FAn & Dec 1 & BAS-E & BAS-S & E. Final \\
\hline Média & 91 & 22 & 21 & 25 & 8 & 6 \\
Mediana & 88 & 22 & 20 & 24 & 8 & 6 \\
\hline Máximo & 150 & 33 & 37 & 47 & 19 & 13 \\
\hline Mínimo & 28 & 8 & 4 & 11 & 1 & 2 \\
\hline Desvio Padrão & 41 & 9 & 10 & 10 & 5 & 3 \\
\hline
\end{tabular}


As concentrações do SST são apresentadas graficamente em Box-plot na Figura 5.26, em que se observa em 50\% dos resultados do afluente (ARS) concentrações entre 73 e 118 $\mathrm{mg} / \mathrm{L}$ e que a mediana é $73 \mathrm{mg} / \mathrm{L}$. No efluente do FAn 50\% dos resultados estão entre 15 e $20 \mathrm{mg} / \mathrm{L}$ e mediana é $22 \mathrm{mg} / \mathrm{L}$. No efluente do BAS 50\% dos resultados estão entre 7 e 9 $\mathrm{mg} / \mathrm{L}$ e mediana é $8 \mathrm{mg} / \mathrm{L}$. Já no efluente final, $50 \%$ dos resultados estão entre 5 e $6 \mathrm{mg} / \mathrm{L}$ e a mediana é $7 \mathrm{mg} / \mathrm{L}$.

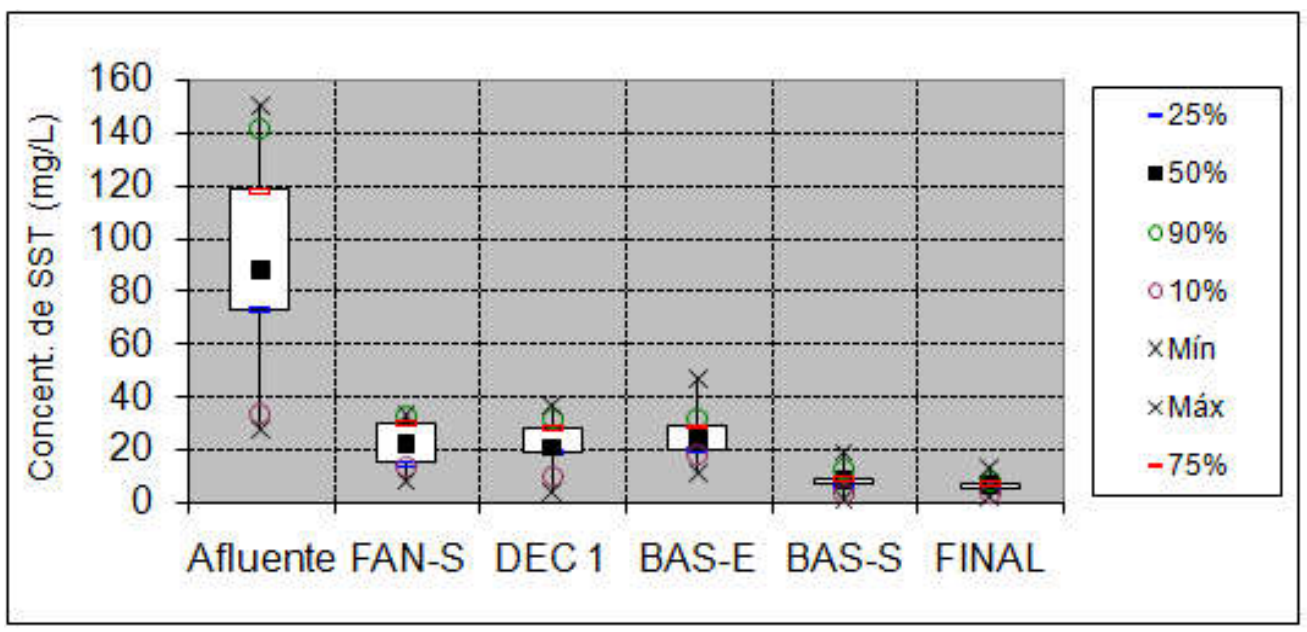

Figura 5.26: Gráfico Box-plot das concentrações de SST

Como se observa na Figura 5.27, a eficiência no sistema combinado manteve-se constante na maior parte do tempo acima de $90 \%$ de remoção, exceto no $70^{\circ}$ dia, o que pode ter sido ocasionado pela falta de reagentes. Porém, a queda na eficiência do sistema global acompanhou a queda nos sistemas FAn e BAS, analisados isoladamente.

A concentração média de SST da ARS foi de $91 \mathrm{mg} / \mathrm{L}$, bem inferior à concentração típica de sólidos suspensos totais no esgoto doméstico, que varia de 200 a $450 \mathrm{mg} / \mathrm{L}$. (Jordão e Pessoa, 2005).

Na Figura 5.28 estão apresentados, em Gráfico Box-plot, os dados obtidos referentes à eficiência de remoção de SST, onde 50\% dos resultados do efluente FAn estão entre 66 e $76 \%$ e a mediana é $73 \%$. 


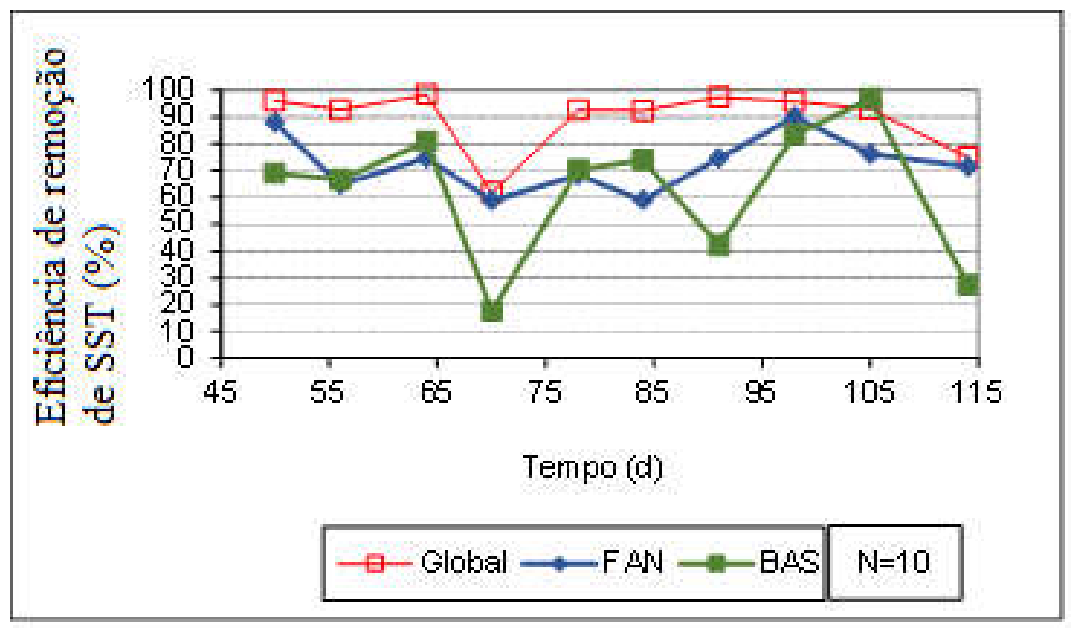

Figura 5.27: Gráfico comparativo da eficiência de remoção de SST

No efluente BAS $50 \%$ dos resultados estão entre 48 e $79 \%$ e a mediana é $70 \%$, já no sistema combinado, $50 \%$ dos resultados obtidos estão entre 92 e $96 \%$ e a mediana é $93 \%$. Como se pode observar, houve maior variação no BAS, o que não causou muito impacto no sistema combinado, que apresentou pouca variação.

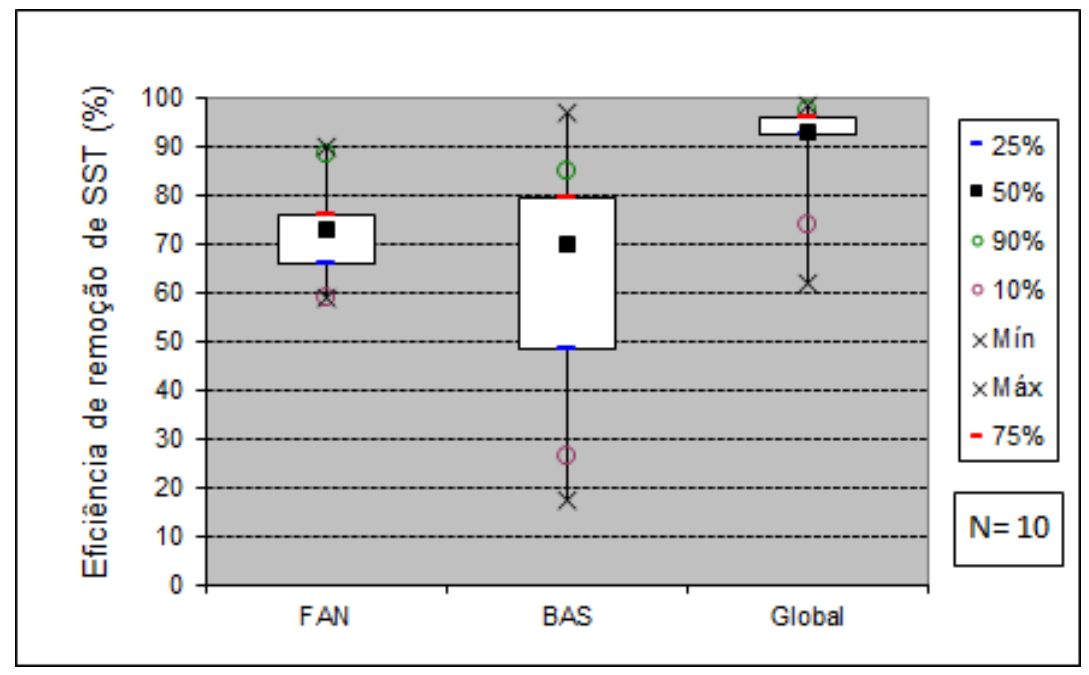

Figura 5.28: Box-plot das eficiências de remoção de SST

O sistema combinado proposto operou com $50 \%$ das eficiências obtidas entre 92 e $96 \%$, com mediana de 93\% e eficiência máxima de 98,3\%. O sistema teve excelente performance recuperando-se rapidamente após operar de modo contingencial, mantendo a eficiência acima de 90\%, como apresentado na Figura 5.29. 
Fazendo uma comparação com a literatura pesquisada, o sistema obteve uma eficiência de remoção de SST global satisfatória, uma vez que o sistema de Barbosa (2006) obteve eficiência média 85,6\%. O sistema de Domingues (2005) obteve eficiência média de $92 \%$ e máxima de 98\%. O sistema combinado de Araújo e Freitas (2014) apresenta eficiência média de 47\%. Foco (2010) obteve 98\% remoção média, em seu sistema combinado. Segundo Gonçalves et al. (2001), as eficiências de remoção esperadas para sistemas combinados anaeróbio-aeróbio, são de 85 a 95\% de SST.

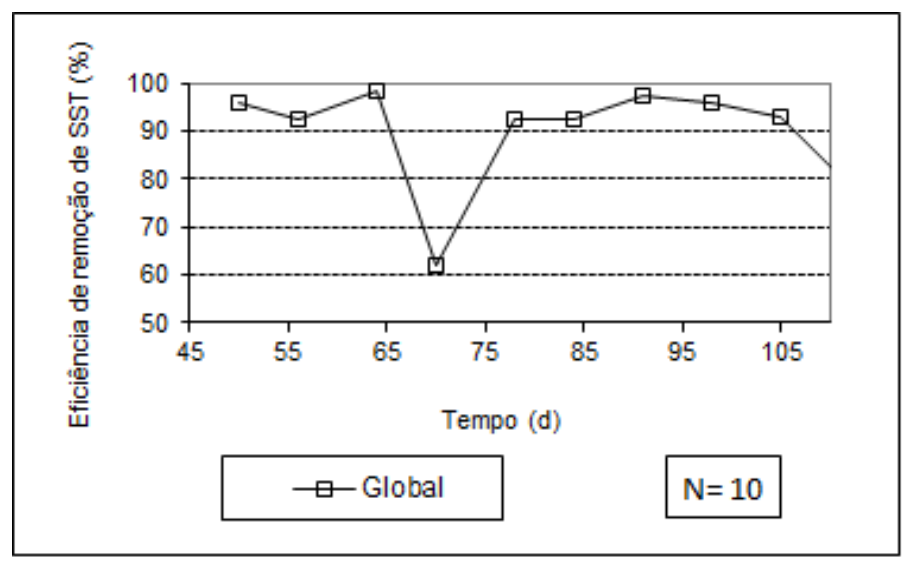

Figura 5.29: Gráfico da eficiência global

\subsection{5 - Turbidez}

A turbidez dá-se por uma grande variedade de sólidos em suspensão, então assim como os SST, obteve-se uma excelente eficiência neste sistema combinado para turbidez, com remoção mínima de 79,7\%, máxima de $99,9 \%$ e média de $97 \%$ e desvio padrão de 4,4. Verificou-se 50\% dos resultados estiveram entre 96,7 e 99,2, com mediana de 98,7\%. Observou-se um efluente final bastante clarificado, com concentrações de turbidez mínima de 0,3 NTU, máxima de 10,2 NTU e média de 1,6 NTU.

No gráfico, apresentado na Figura 5.30, observa-se uma uniformidade nos resultados obtidos para turbidez, com maiores concentrações nos dias $76^{\circ}$ e $105^{\circ}$, provavelmente ocasionados por arraste de sólidos. Diante dos resultados, 50\% estiveram entre 0,6 e 1,2 NTU, com mediana de 1 NTU. 


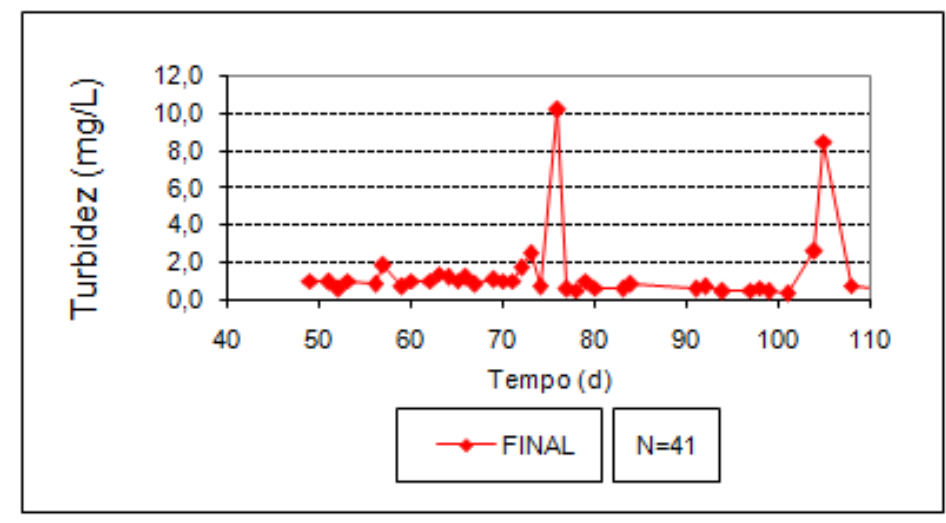

Figura 5.30: Concentrações de turbidez no efluente final.

\subsection{6 - Caracterização Quantitativa e Qualitativa da Biomassa}

5.3.6.1 - Quantificação da biomassa em suspensão e aderida ao meio suporte do Filtro Anaeróbio e do Biofiltro Aeróbio Submerso

$\mathrm{Na}$ Tabela 5.15 estão apresentados os resultados obtidos nas análises de sólidos totais e voláteis realizadas no FAn e no BAS, para a quantificação da biomassa aderida ao meio suporte e a biomassa suspensa retirada do fundo de cada filtro.

Tabela 5.15: Resultados das análises de ST e STV realizadas no FAn e no BAS.

\begin{tabular}{cccc}
\hline Unidade & Característica & ST (mg/L) & STV (mg/L) \\
\hline \multirow{2}{*}{ Filtro anaeróbio } & Biomassa aderida & 925 & 308 \\
\cline { 2 - 4 } & Biomassa em suspensão & 738 & 626 \\
\hline \multirow{2}{*}{ Filtro aeróbio } & Biomassa aderida & 1482 & 657 \\
\cline { 2 - 4 } & Biomassa em suspensão & 334 & 295 \\
\hline
\end{tabular}

De acordo com os resultados obtidos, é possível concluir que o BAS apresentou maior aderência da biomassa quando comparado ao FAn, tanto em termos de ST e de STV, como pode-se observar na Figura 5.31. Em termos de sólidos totais na biomassa aderida, a concentração no BAS foi de $1482 \mathrm{mg} / \mathrm{L}$, porém com menor concentração, de $334 \mathrm{mg} / \mathrm{L}$, na biomassa em suspensão, em comparação ao FAn que obteve maior concentração de biomassa suspensa, com $738 \mathrm{mg} / \mathrm{L}$. 
No BAS, a concentração de sólidos voláteis nos meios em suspensão representou em média $88 \%$ dos sólidos totais e nos meios aderidos em média 44\%. Já no FAn, 33\% dos ST estavam representados em forma de STV na biomassa aderia e em média $85 \%$ da biomassa em suspensão estava representada em STV.

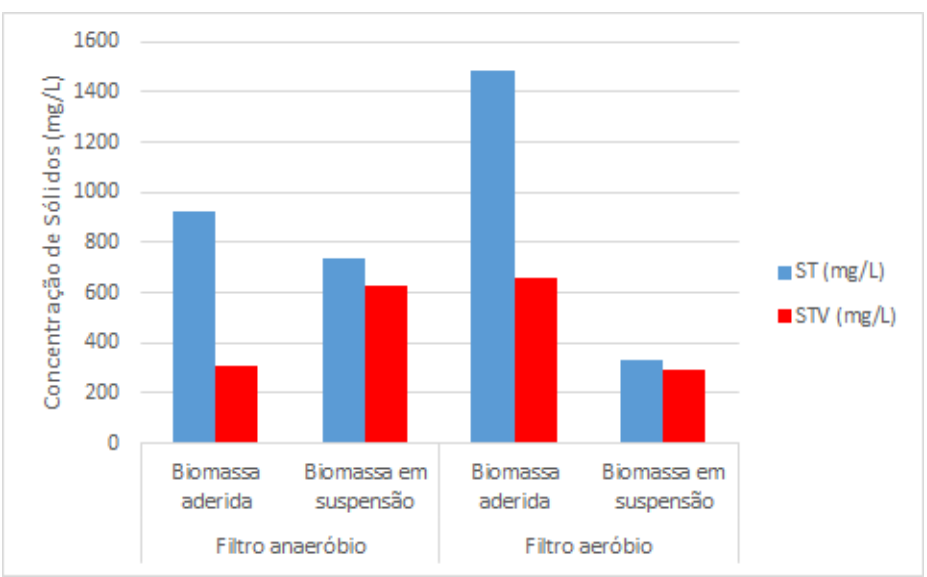

Figura 5.31: Comparação das concentrações de sólidos totais e voláteis obtidas em cada filtro.

Foi realizada a pesagem do meio suporte para a quantificação, em gramas, de biomassa aderida a cada unidade. Na Tabela 5.16 e Tabela 5.17 estão apresentados os valores referentes ao peso de cinco amostras com 10 unidades de meio suporte de cada filtro.

Tabela 5.16: Média do peso da biomassa aderida ao FAn, realizada em 5 conjunto de 10 unidades de meio suporte.

\section{FILTRO ANAERÓBIO}

\begin{tabular}{|c|c|c|c|}
\hline Amostras & $\begin{array}{c}\text { Peso dos } \\
\text { bobs+espuma } \\
\text { c/biomassa } \\
\text { (molhados) }\end{array}$ & $\begin{array}{c}\text { Peso dos } \\
\text { bobs+espuma } \\
\text { molhados } \\
\text { s/biomassa }\end{array}$ & $\begin{array}{l}\text { Peso referente } \\
\text { a biomassa } \\
\text { aderida }\end{array}$ \\
\hline Conj. 1* & 75,1 & 33,3 & 41,9 \\
\hline Conj. 2* & 73,6 & 32,8 & 40,8 \\
\hline Conj. 3* & 81,0 & 31,7 & 49,4 \\
\hline Conj. 4* & 78,7 & 32,6 & 46,1 \\
\hline Conj. 5* & 84,7 & 32,6 & 52,2 \\
\hline Média & 78,7 & 32,6 & 46,1 \\
\hline Média do peso unitário & 7,9 & 3,3 & 4,6 \\
\hline
\end{tabular}

Nota: Foram pesados 5 conjuntos cada um contendo 10 bobs+espuma 
Tabela 5.17: Média do peso da biomassa aderida ao BAS, realizada em 5 conjunto de 10 unidades de meio suporte.

BIOFILTRO AERÓBIO SUBMERSO

\begin{tabular}{|cccc|}
\hline Amostras & $\begin{array}{c}\text { Peso dos } \\
\text { bobs+espuma } \\
\text { c/biomassa } \\
\text { (molhados) }\end{array}$ & $\begin{array}{c}\text { Peso dos } \\
\text { bobs+espuma } \\
\text { molhados } \\
\text { s/biomassa }\end{array}$ & $\begin{array}{c}\text { Peso referente } \\
\text { a biomassa } \\
\text { aderida }\end{array}$ \\
\hline Conj. 1* & 136,3 & 33,2 & 103,0 \\
\hline Conj. 2* & 141,8 & 32,8 & 108,9 \\
\hline Conj. 3* & 150,8 & 31,7 & 119,1 \\
\hline Conj. 4* & 138,9 & 32,6 & 106,3 \\
\hline Conj. 5* & 136,2 & 32,6 & 103,6 \\
\hline Média & $\mathbf{1 4 0 , 8}$ & $\mathbf{3 2 , 6}$ & $\mathbf{1 0 8 , 2}$ \\
\hline Média do peso & $\mathbf{1 4 , 1}$ & $\mathbf{3 , 3}$ & $\mathbf{1 0 , 8}$ \\
\hline unitário & & & \\
\hline
\end{tabular}

*Foram pesados 5 conjuntos cada um contendo 10 bobs+espuma

\subsubsection{2 - Análise Microbiológica no Biofiltro Aeróbio Submerso.}

Os microrganismos foram identificados até o nível de gênero e para a classificação foi utilizada a sistemática de Canler et al.(1999), Madoni (1994) e Streble e Krauter (1987). Os microrganismos foram agrupados em quatro grupos: Classe Ciliata, representada pelos protozoários: livres natantes, ciliados fixos ou pedunculados, ciliados móveis de fundo ou predadores de floco, flagelados e amebas; Classe Rotífera, representada pelos rotíferos; Classe Nematodes, representada pelos nematóides; Classe Clitellata, tipo Annelida, representada pelos anelídeos.

De um modo geral, foram observados em maior presença os protozoários ciliados pedunculados e metazoários, como Rotíferos, Nematóides e Anelídeos, as amostras foram classificadas como organismos mais frequentes e eventuais. Na Figura 5.32 são mostradas imagens adquiridas dos principais grupos encontrados no BAS.

Não foram observadas diferenças em relação à diversidade biológica na biomassa aderida utilizando água deionizada e o efluente. Nos bobs observou-se a presença mais frequente 
de ciliados. Entretanto, houve uma diferença significativa entre a presença de organismos na biomassa em suspensão, notando-se principalmente o aumento da presença de ciliados pedunculados, rotíferos e aelosomas.

A presença de ciliados pedunculados no sistema aeróbio indica operação estável e a ocorrência de formas coloniais é verificada quando a idade do lodo é elevada. A presença do Epistylis sp. Peritrichia, mostrado em colônia na Figura 5.32 (a), está associada a uma operação correta e estável, seu desenvolvimento está relacionado a períodos de anoxia. Este organismo alimenta-se de bactérias, é típico de zona anóxica e sua presença indica boa qualidade do efluente e baixas cargas orgânicas.

Observou-se também a presença dos ciliados Tetrahymena pyriformis sp. Holotricha, mostrado na Figura 5.32 (b), que indica altas cargas e aeração satisfatória; e do Tokophrya sp. Suctoria, mostrado na Figura 5.32 (c), que indicam baixas cargas orgânicas, esse organismo se alimentam de protozoários nadadores e sua presença independe do grau de purificação do sistema.

$\mathrm{Na}$ amostra obtida da raspagem da biomassa aderida ao bob, foram observados os organismos mais frequentes, a saber: rotíferos, oligotrichias, ciliados pedunculados e gastrotriquia. Outros organismos não tão frequentemente observados foram as Tokophrya sp. Suctoria. Nas leituras da biomassa em suspensão foram encontrados ciliados e predominância de rotíferos em todas as amostras.

Segundo Black (2002), os metazoários observados nos sistemas são indicadores de um lodo com certo período de retenção celular, e também são responsáveis pela clarificação do sistema, pois se alimentam dos protozoários e da matéria orgânica ligada ao lodo.

Os rotíferos observados na biomassa do BAS foram o Digononta, mostrado na Figura 5.32 (d), e Monogononta, mostrado na Figura 5.32 (e), indicadores de sistema com baixas cargas orgânicas, elevada idade do lodo (com no mínimo 15 dias) e de eficiência satisfatória do processo de depuração biológica, uma vez que são muito eficientes no consumo de bactérias, dispersas ou aderidas ao floco, e pequenas partículas de matéria orgânica. 
Foi identificada, na biomassa aderida e suspensa, a presença de Aelosomas sp., mostrado na Figura 5.32 (f), da ordem oligocheta. A predominância desse anelídeo indica um efluente com qualidade satisfatória, baixas cargas orgânicas, condições satisfatórias de aeração, eficiência da nitrificação.

Observaram-se também organismos da Classe Nematodes, mostrado na Figura 5.32 (a), ordem gastrotriquia. Os Nematoda sp. não podem ser considerados como um indicador da qualidade do tratamento, estão presentes em todas as cargas orgânicas e são resistentes a baixos níveis de aeração.
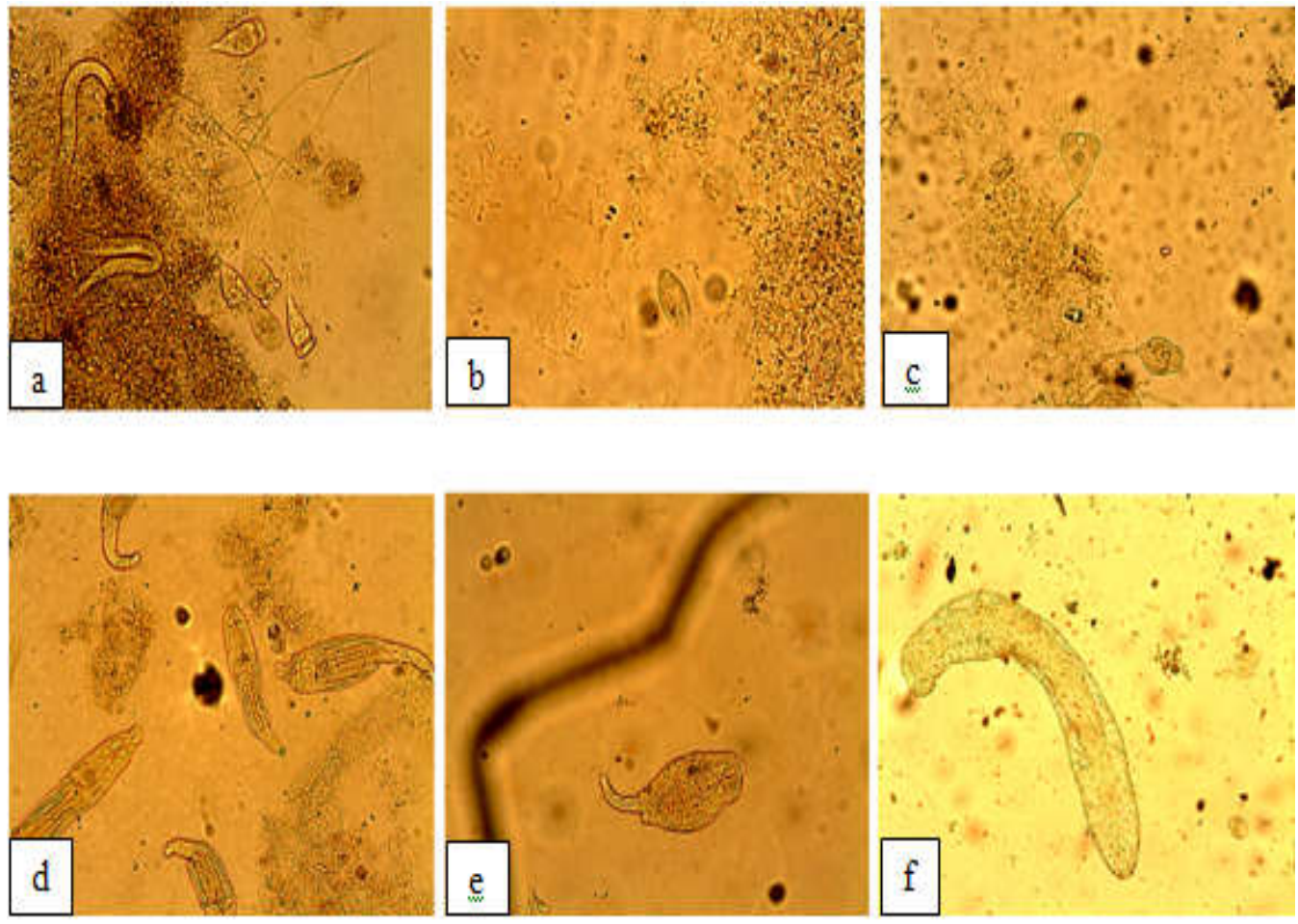

Figura 5.32: Microfauna presente no BAS.

\section{4 - AVAliAÇÃo do SISTEMA COMBINADO QUANTO À PRODUÇÃo DE LODO}

A recirculação de lodo do Dec 2 não causou alterações no desempenho do FAn, assim como nos trabalhos de Domingues (2005), Goffi (2013) e Aisse et al. (2001), reforçando a recomendação de Gonçalves et al. (2001). 
Evidenciou-se a importância de combinar os sistemas anaeróbio e aeróbio, na redução de produção de lodo, uma vez que o FAn e o BAS, analisados isoladamente, geram mais lodo do que quando comparados ao sistema combinado.

Pode-se afirmar que o sistema combinado proposto, com recirculação de lodo aeróbio, admitindo o FAn como único gerador final de lodo, apresentou baixa produção de lodo, $\left(0,03 \mathrm{kgSST} / \mathrm{KgDQO}_{\text {aplicada }}\right)$, quando comparada às estimativas de produção de lodo, por diferentes tipos de tratamento, apresentadas por Von Sperling (2001), que estima, numa

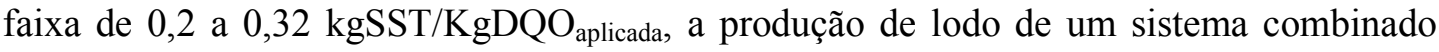
entre UASB seguido de pós-tratamento aeróbio (lodos ativados, biofiltro aerado submerso e filtro biológico).

Quando o sistema combinado (FAn+BAS) é analisado por unidades, estima-se que o FAn gerou em média $0,03 \mathrm{kgSST} / \mathrm{KgDQO}_{\text {aplicada }}$ e o BAS gerou $0,06 \mathrm{kgSST} / \mathrm{KgDQO}_{\text {aplicada }}$ de lodo. Isso se encontra abaixo da faixa de geração de lodo estimada por Von Sperling (2001), para quem essa faixa, para lodo anaeróbio (UASB), ficaria entre 0,12-0,18, e, para o lodo aerado (lodos ativados), entre 0,08 e 0,14 kgSST/KgDQO $\mathrm{K}_{\text {aplicada. }}$

Pode-se associar a baixa produção de lodo, no sistema unitário ou combinado, ao tipo de meio suporte utilizado. As espumas de poliuretano apresentaram elevada capacidade de adesão dos microrganismos, que pode ser atribuída à elevada porosidade e adsorção.

A baixa geração de lodo está relacionada aos bons resultados de eficiência obtidos nas análises de SST, ao longo do monitoramento operacional. O sistema combinado deste trabalho atendeu aos parâmetros para dimensionamento propostos por Gonçalves et al. (2001), que estimaram uma faixa de remoção de 80 - 90\% de DQO e 85 a 95\% de SST, para sistemas combinados (processo anaeróbio seguido de processo aeróbio).

Ao estabelecer uma comparação também em relação às eficiências de remoção de DQO e SST, obtidas por outros sistemas combinados, que operaram com diferentes variáveis e diferentes meios suporte, confirma-se a indicação do sistema combinado por FAn seguido de BAS, utilizando como meio suporte anéis de polipropileno com espuma de poliuretano, no tratamento de águas residuárias domésticas, podendo ser aplicado em residências 
unifamiliares, devido à compactabilidade e atendimento às normas de lançamento de efluentes sanitários.

De modo geral, o sistema pesquisado apresentou maior eficiência quando comparado aos sistemas que usaram como afluente a água residuária sintética, assim como quando comparado aos sistemas que utilizaram a espuma de poliuretano como meio suporte. Porém, quando comparado a sistemas combinados que trataram esgoto sanitário, Foco (2010) também apresentou bons resultados, utilizando como meio suporte eletrodutos corrugados. O sistema de Foco (2010) operou com TDH de 18,6 horas e recirculação de 0,5 e obteve DQO média de $60 \mathrm{mg} / \mathrm{L}$ e $7 \mathrm{mg} / \mathrm{L}$ no efluente final.

A Tabela 5.18 apresenta dados de diferentes pesquisas já realizadas no âmbito experimental, com características operacionais diferentes, apresentando estimativas de produção de lodo, utilizando a relação $\mathrm{kgSST} / \mathrm{KgDQO}_{\text {aplicada, assim como as eficiências }}$ obtidas entre o afluente bruto e efluente final. Com o intuito de apresentar dados comparativos, foram dispostos os dados de diferentes fases das pesquisas realizadas por Araújo e Freitas (2014), Foco (2010), Goffi (2013) e Ávila (2005) na Tabela 5.18.

A pesquisa de Araújo e Freitas (2014) apresentou dados obtidos ao operar o sistema apenas com o UASB, e, em uma segunda fase, apresentou dados de sua pesquisa na associação do UASB seguido de um biofiltro aerado submerso (BAS).

Já sobre as pesquisas de Foco (2010) e Goffi (2013), estão apresentados os dados relativos às fases de operação sem reciclo e com reciclo proveniente do sistema aerado. Por fim, estão apresentados os resultados obtidos por Ávila (2005), ao trabalhar separadamente com três filtros anaeróbios, cada um deles constituído por um tipo diferente de meio suporte, avaliando a eficiência quando operados sob as mesmas condições.

A quantidade de lodo gerado pelo FAn foi estimada em $0,000718 \mathrm{kgSST} / \mathrm{d}$ ou 0,718 gSST/d. Com carga de SST per capita de 0,14352 gSST/hab.d, estimada para uma residência com cinco habitantes. Esses valores encontram-se abaixo da faixa per capita apresentada por Von Sperling (2001), que estimou uma faixa per capita entre 12 e 18 
gSST/hab.d de lodo anaeróbio, proveniente de reator UASB. Assumindo 0,1 kgDQO/hab.d e $0,06 \mathrm{~kg} / \mathrm{hab} . \mathrm{d}$.

Já a quantidade de lodo gerado pelo BAS foi estimada em $0,0003384 \mathrm{kgSST} / \mathrm{d}$ ou 0,3384 gSST/d. A carga de SST per capita foi também estimada em 0,06768 gSST/hab.d, considerando os esgotos provenientes de uma residência com cinco habitantes. Esses valores encontram-se abaixo da faixa per capita apresentada por Von Sperling (2001), que a estimou entre 8 e 14 gSST/hab.d de lodo aeróbio, proveniente de lodos ativados, assumindo cargas de $0,1 \mathrm{kgDQO} / \mathrm{hab} . \mathrm{d}$ e $0,06 \mathrm{~kg} / \mathrm{hab} . \mathrm{d}$. 
Tabela 5.18: Produção de lodo e eficiências de remoção de DQO e SST, obtidas em diferentes sistemas combinados

\begin{tabular}{|c|c|c|c|c|c|c|c|c|c|}
\hline \multirow[t]{2}{*}{ Autor } & \multirow[t]{2}{*}{$\begin{array}{l}\text { Tipo de } \\
\text { Sistema }\end{array}$} & \multirow[t]{2}{*}{ Afluente } & \multirow[t]{2}{*}{ Recheio } & \multirow[t]{2}{*}{ Escala } & \multirow[t]{2}{*}{ Reciclo } & \multicolumn{2}{|c|}{$\begin{array}{c}\text { Produção de lodo } \\
\text { (kgSST/KgDQO }_{\text {aplicada })}\end{array}$} & \multicolumn{2}{|c|}{$\begin{array}{l}\text { Eficiência de } \\
\text { remoção }\end{array}$} \\
\hline & & & & & & Anaeróbio & Aeróbio & $\begin{array}{l}\text { DQO - } \\
\text { Global }\end{array}$ & $\begin{array}{l}\text { SST - } \\
\text { Global }\end{array}$ \\
\hline $\begin{array}{l}\text { Presente } \\
\text { trabalho }\end{array}$ & $\mathrm{FAn}+\mathrm{BAS}$ & ARS & $\begin{array}{l}\text { Espuma de } \\
\text { poliuretano }\end{array}$ & Bancada & $X$ & 0,03 & 0,06 & $94 \%$ & $93 \%$ \\
\hline Foco, 2010 & $\mathrm{FAn}+\mathrm{BAS}$ & $\begin{array}{c}\text { Esgoto } \\
\text { sanitário } \\
\text { Unicamp }\end{array}$ & $\begin{array}{l}\text { Eletrodutos } \\
\text { corrugados }\end{array}$ & Bancada & & 0,04 & 0,02 & $93 \%$ & $95 \%$ \\
\hline Foco, 2010 & $\mathrm{FAn}+\mathrm{BAS}$ & $\begin{array}{l}\text { Esgoto } \\
\text { sanitário } \\
\text { Unicamp }\end{array}$ & $\begin{array}{l}\text { Eletrodutos } \\
\text { corrugados }\end{array}$ & Bancada & $\mathrm{X}$ & 0,02 & 0,04 & $90 \%$ & $93 \%$ \\
\hline Ávila, 2005 & $\mathrm{TS}+\mathrm{FA}$ & $\begin{array}{l}\text { Campus } \\
\text { UFRJ }\end{array}$ & Brita $n^{\circ} 4$ & Piloto & & 0,04 & - & $73 \%$ & $93 \%$ \\
\hline $\begin{array}{c}\text { Achaval, } \\
2014\end{array}$ & $\begin{array}{c}\text { T.IM + FA } \\
\text { FA+Dec }\end{array}$ & $\begin{array}{l}\text { Doméstico } \\
\text { unifamiliar }\end{array}$ & Conduite & Piloto & & 0,4 & - & $78 \%$ & $83 \%$ \\
\hline $\begin{array}{l}\text { Bof et. al., } \\
1999\end{array}$ & $\mathrm{UASB}+\mathrm{BAS}$ & $\begin{array}{l}\text { Esgoto bruto } \\
\text { pré-tratado }\end{array}$ & $\begin{array}{l}\text { Bilhas de } \\
\text { poliestireno }\end{array}$ & Piloto & $X$ & 0,06 & 0,1 & $89 \%$ & $92 \%$ \\
\hline Goffi, 2013 & $\begin{array}{l}\text { Reator } \\
\text { anaeróbio- } \\
\text { aeróbio }\end{array}$ & $\begin{array}{l}\text { Esgoto } \\
\text { sanitário } \\
\text { UTFPR }\end{array}$ & $\begin{array}{l}\text { Espumas de } \\
\text { poliuretano e argila } \\
\text { expandida }\end{array}$ & Bancada & & - & 0,2 & $82 \%$ & $92 \%$ \\
\hline
\end{tabular}


Tabela 5.19: Produção de lodo e eficiências de remoção de DQO e SST, obtidas em diferentes sistemas combinados (cont.)

\begin{tabular}{|c|c|c|c|c|c|c|c|c|c|}
\hline Autor & $\begin{array}{l}\text { Tipo de } \\
\text { Sistema }\end{array}$ & Afluente & Recheio & Escala & Reciclo & \multicolumn{2}{|c|}{$\begin{array}{c}\text { Produção de lodo } \\
\text { (kgSST/KgDQO }_{\text {aplicada) }}\end{array}$} & \multicolumn{2}{|c|}{$\begin{array}{l}\text { Eficiência de } \\
\text { remoção }\end{array}$} \\
\hline Goffi, 2013 & $\begin{array}{l}\text { Reator } \\
\text { anaeróbio- } \\
\text { aeróbio }\end{array}$ & $\begin{array}{l}\text { Esgoto } \\
\text { sanitário } \\
\text { UTFPR }\end{array}$ & $\begin{array}{c}\text { Espumas de } \\
\text { poliuretano e argila } \\
\text { expandida }\end{array}$ & Bancada & $\mathrm{X}$ & - & 0,1 & $82 \%$ & $92 \%$ \\
\hline Ávila, 2005 & $\mathrm{TS}+\mathrm{FA}$ & $\begin{array}{l}\text { Campus } \\
\text { UFRJ }\end{array}$ & Anéis de Plástico & Piloto & & 0,06 & - & $70 \%$ & $90 \%$ \\
\hline Ávila, 2005 & $\mathrm{TS}+\mathrm{FA}$ & $\begin{array}{l}\text { Campus } \\
\text { UFRJ }\end{array}$ & Cubos de espuma & Piloto & & 0,1 & - & $68 \%$ & $90 \%$ \\
\hline $\begin{array}{l}\text { Domingues, } \\
2005\end{array}$ & $\mathrm{FAn}+\mathrm{BAS}$ & Doméstico & $\begin{array}{c}\text { Anéis de } \\
\text { polipropileno } \\
\text { perfurados (bob) }\end{array}$ & Bancada & & 0,2 & 0,1 & $87 \%$ & $91 \%$ \\
\hline $\begin{array}{l}\text { Barbosa, } \\
2006\end{array}$ & $\mathrm{TS}+\mathrm{BAS}$ & ARS & Argila expandida & Bancada & & 0,1 & 0,1 & $90 \%$ & $85,6 \%$ \\
\hline $\begin{array}{c}\text { Araújo e } \\
\text { Freitas, } 2014\end{array}$ & UASB & ARS & - & Bancada & & 0,1 & & $31 \%$ & $81 \%$ \\
\hline $\begin{array}{l}\text { Aisse et. al., } \\
2001\end{array}$ & $\mathrm{UASB}+\mathrm{BAS}$ & Doméstico & $\begin{array}{l}\text { Colméia de } \\
\text { plástico }\end{array}$ & Piloto & $\mathrm{X}$ & 0,6 & 0,1 & $78 \%$ & $75,9 \%$ \\
\hline $\begin{array}{c}\text { Araújo e } \\
\text { Freitas, 2014 }\end{array}$ & UASB+BAS & ARS & $\begin{array}{l}\text { Espuma de } \\
\text { poliuretano }\end{array}$ & Bancada & $\mathrm{X}$ & 0,7 & 0,6 & $77 \%$ & $47 \%$ \\
\hline
\end{tabular}




\section{5 - Atendimento ao Padrão Nacional de Lançamento de Efluentes Líquidos e Reúso de Água}

O sistema combinado proposto atendeu aos limites de lançamento, apresentados na Tabela 5.20, em âmbito nacional, assim como as normas especificas de cada estado.

Tabela 5.20: Resultado do sistema combinado comparado aos padrões de lançamento.

\begin{tabular}{|c|c|c|c|c|c|}
\hline & $\mathbf{T}\left({ }^{\circ} \mathrm{C}\right)$ & pH & DQO (mg/L) & $\mathrm{DBO}_{5}(\mathrm{mg} / \mathrm{L})$ & Sólidos (mg/L) \\
\hline FAn+BAS & 26,6 & 7,9 & 30 & 12 & $\begin{array}{l}\text { SSed } 0 \\
\text { SST } 6\end{array}$ \\
\hline BRASIL & $<40$ & 5 a 9 & - & $\begin{array}{c}\leq 120 \text { ou } \\
\text { eficiência }>60 \%\end{array}$ & SSed $\leq 1$ \\
\hline $\mathbf{A L}$ & $<40$ & 5 a 9 & 150 & 60 & SSed $\leq 1$ \\
\hline CE & $<40$ & 5 a 9 & 200 & - & $\begin{array}{l}\text { SSed } \leq 1 \\
\text { SST } \leq 50\end{array}$ \\
\hline GO & $<40$ & 5 a 9 & - & $\begin{array}{c}\leq 60 \text { ou eficiência } \\
>80 \%\end{array}$ & $\mathrm{SSed} \leq 1$ \\
\hline MT & $<40$ & 5 a 9 & 120 & 60 & SSed $\leq 1$ \\
\hline MS & $<40$ & 5 a 9 & - & $\begin{array}{c}\leq 120 \text { ou } \\
\text { eficiência }>80 \%\end{array}$ & SSed $\leq 1$ \\
\hline MG & $<40$ & 6 a 9 & $\begin{array}{c}\leq 180 \text { ou } \\
\text { eficiência }> \\
65 \%\end{array}$ & $\begin{array}{c}\leq 60 \text { ou eficiência } \\
>70 \%\end{array}$ & $\begin{array}{c}\mathrm{SSed} \leq 1 \\
\mathrm{SST} \leq 100\end{array}$ \\
\hline PR & $<40$ & 5 a 9 & 225 & 90 & - \\
\hline RJ & $<40$ & 5 a 9 & - & $\begin{array}{c}180 / 30 \%(\mathrm{C} \leq \\
5)^{(1)} 100 / 60 \%(5 \\
<\mathrm{C} \leq 25) 60 / 80 \% \\
(25<\mathrm{C} \leq 80) \\
40 / 85 \%(\mathrm{C}>80)\end{array}$ & $\begin{array}{c}\text { SSed } \leq 1 \mathrm{SST}^{(1)}: \\
180 / 30 \%(\mathrm{C} \leq 5) \\
100 / 60 \%(5<\mathrm{C} \leq 25) \\
60 / 80 \%(25<\mathrm{C} \leq 80) \\
40 / 85 \%(\mathrm{C}>80)\end{array}$ \\
\hline RS & $<40$ & 5 a 9 & $\leq 360(\mathrm{Q}<200)$ & $\leq 120(\mathrm{Q}<200)^{(2)}$ & $\begin{array}{c}\mathrm{SSed} \leq 1 \\
\mathrm{SST} \leq 120(\mathrm{Q}<200)^{(2)}\end{array}$ \\
\hline RO & $<40$ & $\begin{array}{c}5,8 \mathrm{a} \\
9,7\end{array}$ & - & - & $\mathrm{SSed} \leq 1$ \\
\hline SC & $<40$ & 6 a 9 & - & $\begin{array}{c}\leq 60 \text { ou eficiência } \\
>80 \%\end{array}$ & SSed $\leq 1$ \\
\hline SP & $<40$ & 5 a 9 & - & $\begin{array}{c}\leq 60 \text { ou eficiência } \\
>80 \%\end{array}$ & $\mathrm{SSed} \leq 1$ \\
\hline
\end{tabular}

(1) De acordo com a carga orgânica diária bruta (kg DBO/dia).

${ }^{(2)}$ De acordo com a vazão diária de lançamento $\left(\mathrm{m}^{3} / \mathrm{d}\right)$.

Os estados que não possuem uma legislação própria para padrões de lançamento de esgoto sanitário, são regidos pela resolução CONAMA 430/2011, como é o caso do Distrito Federal. 
Devido à alta concentração de nutrientes no efluente final do sistema combinado, o efluente não atenderia a resolução CONAMA n 357 de 17 de março de 2005, que dispõe que o lançamento do efluente de uma estação de tratamento tem que atender a capacidade de suporte do corpo receptor, para não comprometer a qualidade da água e seus usos determinados pela classe de enquadramento.

Tendo em vista o uso consciente e sustentável da água faz-se necessário difundir e aplicar o uso consciente da água, visando seu reúso. Entretanto é preciso que se tenham alguns cuidados e por isso a resolução Federal no 54/2006 do CNRH e a NBR-13969/97 regulamentam e instituem alguns padrões para reúso de água.

O efluente final obtido pelo sistema combinado precisaria passar por uma etapa de desinfecção ou cloração para atender a NBR-13969/97. O efluente atendeu em mais de $80 \%$ das amostras aos parâmetros de turbidez (89\%), pH (82\%) e em $100 \%$ quanto aos parâmetros de SST e OD. Por ter sido utilizado água residuária sintética não foram realizadas análises para coliformes fecais.

O efluente final obtido após o tratamento do sistema combinado obteve boa eficiência na remoção de nitrogênio com $94 \%$ e $41 \%$ na remoção de fósforo, porém as concentrações de fósforo e de nitrato ficaram bem acima das estabelecidas pelo CONAMA $n^{0}$ 357/05. Indicado então ao reuso na agricultura, e na piscicultura, segundo pesquisas que vem sendo realizadas neste âmbito. Para efeito de comparação, estão apresentadas na Tabela 5.21 as concentrações obtidas no efluente final. Na Tabela 5.22 encontram-se as concentrações de nutrientes presentes em esgoto tratado que obtiveram sucesso na irrigação, de acordo com o cultivo.

Tabela 5.21: Características do Efluente final

\begin{tabular}{ccc}
\hline & N & Média \pm DP \\
\hline NTK & 3 & $4 \pm 3,4$ \\
N-nitrito $(\mathbf{m g} / \mathbf{L})$ & 9 & $1 \pm 2$ \\
\hline N-nitrato $(\mathbf{m g} / \mathbf{L})$ & 9 & $15 \pm 8$ \\
Fósforo Total & 9 & $13 \pm 9$ \\
\hline
\end{tabular}


Tabela 5.22: Concentração de nutrientes nas irrigações com esgoto tratado - PROSAB 5

\begin{tabular}{cccc}
\hline Cultura & Local & Nitrogênio (mg/L) & Fósforo (mg/L) \\
\hline Mamona & Aquiraz/ CE & 7,9 & 0,64 \\
Cana-de-açúcar & Lins/ SP & 33,3 & 4,5 \\
Capim Tifton-85 & Lins/ SP & 29,3 & 4 \\
Eucalipto & Franca/ SP & 59,9 & 11,7 \\
Milho & Porto Alegre/ RS & 25 & 14 \\
\hline
\end{tabular}

Fonte: Pesquisas do PROSAB 5 (2009). 


\section{6 - CONCLUSÕES E RECOMENDAÇÕES}

\section{1 - CONCLUSÕES}

O sistema combinado proposto, composto por filtro anaeróbio (FAn) seguido de biofiltro aerado submerso (BAS), com meio suporte composto por meio suporte de polipropileno com recheio de espuma, mostrou-se uma alternativa viável para o tratamento de uma água residuária sintética com características de esgoto unifamiliar. Esse sistema combinado manteve eficiência satisfatória, mesmo quando submetido a variações de carga de DQO.

O sistema combinado pesquisado apresentou, nas condições testadas, baixa geração de lodo quando comparado a outros sistemas de tratamento biológico anaeróbio e aeróbio, com diferentes meios suportes. Dos resultados obtidos, foi possível concluir que o meio suporte utilizado, associado às caraterísticas operacionais aplicadas, foram responsáveis pela eficiência reportada.

O sistema combinado FAn seguido de BAS, com meio suporte de espuma de poliuretano envolto por anel de polipropileno, além do bom desempenho e baixa geração de lodo, mostrou simplicidade operacional, característica desejável em sistemas descentralizados.

Com efeito, o sistema combinado FAn seguido de BAS, com meio suporte de espuma de poliuretano envolto por anel de polipropileno, nas condições testadas, apresentou $94 \%$ de eficiência de remoção de DQO e 93\% de eficiência de remoção de SST.

As unidades FAn e BAS, consideradas isoladamente, também obtiveram desempenho considerado satisfatório, sendo que o FAn apresentou eficiência média de $77 \%$ de remoção de DQO com concentração média de efluente de $138 \mathrm{mg} / \mathrm{L}$, e o BAS apresentou eficiência média de 66\% para a remoção de DQO com concentração média de efluente de $48 \mathrm{mg} / \mathrm{L}$.

Foi possível concluir que as unidades FAn e BAS, com meio suporte de espuma de poliuretano, foram as principais responsáveis pela remoção dos ST e SST no sistema. Os decantadores empregados, por sua vez, apresentaram baixa eficiência para estes tipos de sólidos. 
Concluiu-se que a unidade FAn respondeu satisfatoriamente ao procedimento adotado para inoculação, tendo alcançado a estabilidade após a partida entre os dias $45^{\circ}$ e $49^{\circ}$ de operação.

Após estabilização do sistema, o efluente final, atendeu, em 100\% das amostras, ao padrão para efluentes de sistemas de tratamento de esgoto sanitários, quanto aos parâmetros de $\mathrm{pH}$, sólidos sedimentáveis, temperatura e remoção mínima de $\mathrm{DBO}$, estabelecido pela Resolução $n^{\circ}$ 430/11 do CONAMA.

O efluente final do sistema combinado atendeu às normas estatuais que estabelecem padrão para os efluentes sanitários, quanto aos parâmetros de SST, apresentando remoção média de $93 \%$ com concentração final média do efluente de $6 \mathrm{mg} / \mathrm{L}$.

As unidades FAn e BAS operaram de acordo com o esperado, uma vez que o FAn operou em condições anaeróbias e a microfauna encontrada no BAS foi condizente para um sistema aeróbio com estabilidade operacional e condições satisfatórias de aeração.

Por meio da análise e quantificação da biomassa aderida ao meio suporte, observou-se que o meio suporte atendeu aos parâmetros esperados de um meio suporte eficiente, tendo apresentado elevada retenção da biomassa e se comportado como um material inerte, nãobiodegradável e indeformável.

\section{2 - RECOMENDAÇÕES}

Após as avaliações dos resultados obtidos e visando subsidiar trabalhos futuros no tratamento de esgotos sanitários unifamiliares, sugerem-se as ações que são apresentadas a seguir.

Verifica-se que os sistemas descentralizados de esgotos trabalham com condições extremas de gradientes de carga hidráulica e de concentração, podendo receber também, de forma esporádica, elementos de baixa biodegradação e alta toxicidade. Por essa razão,

recomenda-se que o mesmo sistema testado nesta pesquisa, o sistema combinado de FAn 
seguido de BAS, com meio suporte de espuma de poliuretano, seja testado sob condições reais, em escala piloto, em uma instalação in situ, tratando esgoto unifamiliar. Nessas condições reais, será interessante verificar o consumo energético do sistema, a área requerida para instalação, e o volume total de reatores necessário para se obter desempenho satisfatório em cenários de maior exigência ambiental ou em condições de reúso de água para diferentes finalidades.

No caso de se continuar os experimentos com esse sistema em escala de bancada, recomenda-se avaliar a performance do sistema combinado operando com variações de vazões que simulem as variações que ocorrem em condições reais de sistemas de tratamento descentralizado.

A recirculação do lodo na presente pesquisa foi feita de forma intermitente. Portanto, seria importante verificar se o desempenho do sistema quando submetido a vazões constantes de recirculação do lodo efluente do biofiltro aerado submerso se mantém.

Da mesma forma, na presente pesquisa não foi avaliada a capacidade e as condições sob as quais o sistema combinado FAn-BAS pode remover nitrogênio e fósforo. Por isso, seria importante que, em continuidade, a pesquisa premiasse a avaliação do desempenho do sistema combinado FAn-BAS quanto à remoção de nutrientes.

Na presente pesquisa, a minimização da geração de lodo pelo sistema combinado FAnBAS foi verificada pela comparação dos resultados obtidos por outros autores, nem sempre nas condições idênticas às usadas nesta pesquisa. Dessa forma, recomenda-se conceber um delineamento experimental para avaliar a geração de lodo utilizando o mesmo meio suporte, que seja composto de quatro fases ou reatores diferentes, sendo a primeira fase operando um sistema unitário de FAn. Na segunda fase ou reator deveria ser operado um sistema unitário BAS recebendo a mesma carga orgânica submetida ao FAn. Na terceira fase operar-se-ia um sistema combinado composto por FAn seguido de BAS sem reciclo do lodo aeróbio. E, finalmente, na quarta e última fase, seria operado um sistema combinado composto por FAn seguido de BAS com reciclo do lodo aeróbio. Da comparação da produção de lodo em cada fase, poder-se-ia ter resultado mais preciso do potencial de minimização da geração de lodo pelo sistema combinado testado. 


\section{REFERÊNCIAS BIBLIOGRÁFICAS}

Abreu, S. B.; Zaiat, M. (2008) Desempenho de reator anaeróbio-aeróbio de leito fixo no tratamento de esgoto sanitário. Engenharia Sanitária e Ambiental. Rio de Janeiro, v. 13, n. 2, p. 181-188.

Achaval, L. S. (2014). Desenvolvimento e avaliação de um protótipo de estação compacta para tratamento de esgoto em unidades residenciais unifamiliares. Dissertação de Mestrado em Tecnologia Ambiental e Recursos Hídricos. Departamento de Engenharia Civil e Ambiental, Universidade de Brasília, Brasília, DF.

Agra, C. de A. (2009). Tratamento de águas residuárias domésticas em reatores de biomassa dispersa e biomassa aderida. Dissertação (Mestrado). Universidade Federal da Paraíba, Campina Grande.

Aisse, M.M., Sobrinho, P.A. (2001) "Avaliação do sistema reator UASB e filtro biológico aerado submerso para tratamento de esgoto sanitário". Pós-tratamento de efluentes de reatores anaeróbios; Coletânea de Trabalhos Técnicos -Volume 2. Belo Horizonte.

Andrade Neto, C.O (1997). Sistemas simples para tratamento de esgotos sanitários: experiência brasileira. Rio de Janeiro: $A B E S$.

Andrade Neto, C. O. De; Haandel, A. Van; Melo, H. N. S. (2002). O Uso do Filtro Anaeróbio para Pós-Tratamento de Efluentes de Reatores Anaeróbios no Brasil. In: X SIMPÓSIO LUSO-BRASILEIRO DE ENGENHARIA SANITÁRIA E AMBIENTAL, 2002, Braga, Portugal. Anais do X Simpósio Luso-Brasileiro de Engenharia Sanitária e Ambiental. Braga: APESB/APRH/ABES.

APHA, AWWA; WPCF (1999). "Standard methods for examination of water and wastewater". 20th edition, American Public Health Association, American Water Works Association, Water Pollution Control Federation, Washington DC, USA.

Araújo, A. P. C. S, Freitas, B. O (2014). Remoção de matéria orgânica e oxidação do nitrogênio amoniacal presente em esgoto sanitário por sistema combinado UASB e biofiltro aerado submerso. In: Enciclopédia Biosfera, Centro Cientifico Conhecer. Goiânia, v. 10, n. 19, p. 1643. 
Associação Brasileira de Normas Técnicas (1997). NBR 13.969: Tanques Sépticos Unidade de Tratamento Complementar e Disposição Final dos Efluentes Líquidos Projeto, Construção e Operação. Rio de Janeiro.

Ávila, R. O. (2005). Avaliação do Desempenho de Sistemas Tanque Séptico-Filtro Anaeróbio com Diferentes Tipos de Meio Suporte. Dissertação (Mestrado) Universidade Federal do Rio de Janeiro - UFRJ. Rio de Janeiro.

Barbosa, S. A. (2006). Avaliação de Biofiltro Aerado Submerso no Pós-Tratamento de Efluente de Tanque Séptico. Dissertação (Mestrado) - Universidade Federal do Paraná. Curitiba.

Bioproj. Características do Biobob ${ }^{\circledR}$ Disponível em: $<$ http://www.bioproj.com.br/biobob.html > . Acessado em: 02/05/2015.

Black, J.G. (2002). Microbiology. Principles and Explorations. John Wiley \& Sons, New York: $762 \mathrm{pp}$.

Bof, V. B.; Castro, M. S. M.; Gonçalves, R. F. (1999). "ETE UASB + Biofiltro Aerado Submerso: Desempenho operacional com retorno do lodo Aeróbio Para O UASB". In: Anais eletrônicos do $20^{\circ}$ Congresso de Engenharia Sanitária e Ambiental, Rio de Janeiro.

Busato, R. (2004). Desempenho de um Filtro Anaeróbio de Fluxo Ascendente como Tratamento de Efluente de Reator UASB: Estudo se Caso da ETE de Imbituva. Dissertação (Mestrado) - Universidade Federal do Paraná. Curitiba.

Canler, J.P.; Perret, J.M.; Duchene, F.; Cotteaux, E. (1999). Aide au Diagnostic des Stations d'Èpuration par l'observation Microscopique des Boues Activeés. Cemagref Editions, Lyon.

Castagnato, R. (2006). Tratabilidade de esgoto sanitário contendo formaldeído em um sistema combinado filtro anaeróbio- biofiltro aerado submerso. Dissertação (Mestrado) - Universidade Estadual de Campinas, Faculdade de Engenharia Civil, Arquitetura e Urbanismo. Campinas, SP. 
Chernicharo, C. A. L. (1997). Reatores Anaeróbios. Principios do Tratamento Biológico de Águas Residuárias. Belo Horizonte: Departamento de Engenharia Sanitária e Ambiental - UFMG, Vol. 5. 380p.

Chernicharo, C.A.L. (2001). Pós-tratamento de Efluentes de Reatores Anaeróbios. Programa de Pesquisas em Saneamento Básico. PROSAB, Belo Horizonte.

Chernicharo, C.A.L.; Porto, M.T.R.; Pontes, P.P.; Bejar, D.O. (2001). Influência da altura do meio suporte na eficiência de um filtro biológico percolador utilizado para póstratamento de efluentes de um reator UASB. Pós-tratamento de efluentes de reatores anaeróbios. Coletânea de Trabalhos Técnicos, PROSAB, Belo Horizonte, vol. 2.

CONAMA (2011). Resolução 430. "Dispõe sobre condições e padrões de lançamento de efluentes, complementa e altera a Resolução no 357, de 17 de março de 2005, do Conselho Nacional do Meio Ambiente - CONAMA. ”. Brasília, DF.

Correa, C. Z. (2014). Uso de micro-organismos eficientes (EM's) na formação de biofilmes em espuma de poliuretano no tratamento de esgoto sanitário. Monografia (Graduação) Curso Superior em Bacharelado de Engenharia Ambiental. Universidade Tecnológica Federal do Paraná, Londrina.

Coura, M. d., \& Van Haandel, A. C. (1999). Viabilidade técnica e econômica do digestor anaeróbio de fluxo ascendente (UASB) no sistema anaeróbio/aeróbio. 20. ${ }^{\circ}$ Congresso Brasileiro de Engenharia Sanitária e Ambiental.

De Carvalho Jr, Orlando (2004). Aprimoramento de um biofiltro aerado submerso empregado no pós-tratamento do efluente de reator anaeróbio compartimentado. Dissertação (Mestrado) - Escola de Engenharia de São Carlos, USP. São Carlos.

Della Giustina, S. V. (2009). Remoção biológica de nitrogênio utilizando biofiltro aerado submerso multi-estágio. Dissertação (Mestrado em Recursos hídricos e Saneamento Ambiental) Universidade Federal do Rio Grande do Sul, Porto Alegre.

Del Pozo, R.; Diez, V. (2003). Organic matter removal in combined anaerobic-aerobic fixed-film bioreactors. Water Research 3561-3568. 
Domingues, L.G.; Seco, E.L.V.; Nour, E.A.A. (2003). Partida de um sistema combinado filtro anaeróbio - biofiltro aerado submerso tratando esgoto sanitário. $23^{\circ}$ Congresso Brasileiro de Engenharia Sanitária Ambiental. ABES, Joinville-Santa Catarina.

Domingues, L.M. (2005). Sistema combinado filtro-anaeróbio-biofiltro aerado submerso: avaliação da partida e da nitrificação do esgoto sanitário. Dissertação (Mestrado em Saneamento e Ambiente) - Faculdade de Engenharia Civil, Urbanismo e Arquitetura, Universidade de Campinas, Campinas.

Felizatto, M. R. (2002). ETE CAGIF: projeto integrado de tratamento avançado e reúso direto de águas residuárias. In Anais XXI Congresso Brasileiro de Engenharia Sanitária e Ambiental. João Pessoa: Associação Brasileira de Engenharia Sanitária e Ambiental.

Foco, M. L. R. (2010). Filtro anaeróbio seguido de biofiltro aerado submerso: produção de biomassa, conversão de matéria orgânica e de nitrogênio. Dissertação (Mestrado em Engenharia Civil) - Faculdade de Engenharia Civil, Arquitetura e Urbanismo da Universidade Estadual de Campinas. Campinas, SP.

Fontana, H. (2007). Pós-tratamento de esgoto sanitário com biofiltro aerado submerso preenchido com carvão granular: desempenho técnico e estudo de viabilidade econômica. Dissertação (Mestrado) - Escola de Engenharia de São Carlos, Universidade de São Paulo. São Carlos, SP.

Fried, J. e Lemmer, H. (2003). On the dynamics and function of ciliates in sequencing batch biofilm reactors. Water Science \& Technology, v.47, n.5, p.189-196.

Fujii, F. Y. (2011). Análise comparativa entre o processo de lodo ativado e o reator de biofilme de leito móvel na remoção de nitrogênio de esgoto sanitário. Dissertação (Mestrado) - Escola Politécnica da Universidade de São Paulo. Departamento de Engenharia Hidráulica e Sanitária. São Paulo, SP.

Godoy, T.G. de. (2007). Biofiltro Aerado Submerso aplicado ao pós-tratamento de efluente de reator UASB, sob condições hidráulicas desfavoráveis. Estudo em escala real. Dissertação (Mestrado). São Carlos: Escola de Engenharia de São Carlos, Universidade de São Paulo. 177 p. 
Goffi, A. S. (2013). Tratamento de esgoto doméstico em um reator anaeróbio-aeróbio de leito fixo com recirculação da fase líquida. Trabalho de Conclusão de Curso (Bacharelado em Engenharia Ambiental) - Universidade Tecnológica Federal do Paraná. Campo Mourão.

Gonçalves, R.F.; Araújo, V.L.; Chernicharo, C.A.L. (1997). Tratamento secundário de esgoto sanitário através da associação em série de reatores UASB e biofiltros aerados submersos. In: $19^{\circ}$ Congresso Brasileiro de Engenharia Sanitária e Ambiental. ABES, Foz do Iguaçu-PR.

Gonçalves, R.F.; Chernicharo, C.A.L.; Andrade, C.O.; Alem, P.; Kato, M.T.; Costa, R.H.R.; Aisse, M.M.; Zaiat, M. (2001). Pós-tratamento de efluentes de reatores anaeróbios por reatores com biofilme. Chernicharo, C.A.L (Coord.). In: Capítulo 4. "Pós-Tratamento de Efluentes de Reatores Anaeróbios - coletânea de trabalhos. Belo Horizonte, $1^{\text {a }}$ Ed.

Hassell, D.G.; Law, C. L.; Chong, M. F.; Chan, Y. J. (2009). A review on anaerobicaerobic treatment of industrial and municipal wastewater. Chemical Engineering Journal, (155), 1-18.

IBGE, I. B. (2011). Atlas de Saneamento. Acesso em 25 de Fevereiro de 2015, disponível em

IBGE: http://www.ibge.gov.br/home/estatistica/populacao/atlas_saneamento/publicacao.htm 1. Acesso em 02 de março de 2015.

Jordão, E. P.; Pessôa, C. A. (2009). Tratamento de Esgotos Domésticos. 5a ed. Rio de Janeiro: ABES. 940p.

Kato, M.T; Andrade Neto, C.O.; Chernicharo, C.A.L.; Foresti, E.; Cybis, L.F. (1999). Configurações de reatores anaeróbios. In: CAMPOS, J.R. (Coord.) Tratamento de esgotos sanitários por processo anaeróbio e disposição controlada no solo. Rio de Janeiro: PROSAB.

Lima, A.B.B.V.; Gadotti, R.F.; Daniel, L.A. (2005). Pós-Tratamento de efluentes de reator anaeróbio em sistema combinado constituído de ozonização e filtro biológico aeróbio 
submerso. $23^{\circ}$ Congresso Brasileiro de Engenharia Sanitária e Ambiental (ABES), João Pessoa.

Madoni, P. (1994) La Microfauna Nell'Analisi di Qualitá Biologica dei fanghi Attivi, Azienda Gas Acqua Consorziale di Reggio Emilia, Reggio Emilia.

Martins, P. M. (2014). Biofiltro Aerado Submerso Preenchido Com Biobob ${ }^{\circledR}$ Aplicado ao Tratamento de Efluente de Campus Universitário. Trabalho de Conclusão de Curso Universidade Tecnológica Federal do Paraná. Londrina.

Massoud, May A, Akram Tarhini, Joumana A. Nasr. (2009). Decentralized approaches to wastewater treatment and management: Applicability in developing countries. Journal of Environmental Management 90.

Mendonça, L.C. (2002) Microbiologia e cinética de lodos ativados como pós-tratamento de efluente de reator anaeróbio de leito expandido. Tese (doutorado). Escola de Engenharia de São Carlos. Universidade de São Paulo, São Carlos.

Metcalf \& Eddy (1991). Wastewater engineering: treatment, disposal and reuse. 3. Ed, 1334p.

Michelan, R. (2006). Influência do Tipo de Impelidor sobre o Desempenho do Reator Anaeróbio em Batelada Sequencial com Biomassa Granulada Tratando Esgoto Sintético. Dissertação (Mestrado) - Escola de Engenharia de São Carlos, USP. São Carlos.

Moore, R.; Quarmby, J., Stephenson, T. (2001). The effect of media size on the performance of biological aerated filter. Water Research, vol. 35 (10), p. 2514-2522.

Mota F. S. B., Von Sperling M. (2009). Nutrientes de esgoto sanitário: utilização e remoção. Fortaleza: ABES. 428 p. (Projeto PROSAB; 5).

Pescador, F. S. (2001). Tratamento de Esgoto Doméstico em Reatores Sequenciais em Batelada Anaeróbios (RSBAn). Dissertação (Mestrado). Universidade Federal do Rio Grande do Sul, UFRGS. Porto Alegre.

Pesquisa Nacional de Saneamento Básico (PNSB) (2008). Instituto Brasileiro de Geografia e Estatística. 219p. 
Silva, G. H. (2004). Sistema de Alta Eficiência para Tratamento de Esgoto Residencial Estudo de Caso na Lagoa da Conceição. Trabalho de Conclusão do Curso de Graduação em Engenharia Civil da Universidade Federal de Santa Catarina, para a obtenção do título de Engenheiro Civil.

Silva, Ariovaldo J. da. (2005). Biodessulfatação com posterior oxidação parcial do sulfeto em reatores operados em bateladas Sequenciais. 2005. 188f. Tese (Doutorado em Hidráulica e Saneamento) - Escola de Engenharia de São Carlos, Universidade de São Paulo, São Carlos.

Sistema Nacional de Informações sobre Saneamento - SNIS. (2014). Diagnóstico dos Serviços de Água e Esgotos. Brasília: SNSA/MCIDADES.

Sitônio, C. P. (2001). Pós-tratamento de efluentes de reatores anaeróbios utilizando biofiltro aerado submerso. Dissertação (Mestrado) - Escola de Engenharia de São Carlos, USP. São Carlos.

SNIS (2016). Sistema Nacional de Informações sobre Saneamento: Diagnóstico dos Serviços de Água e Esgotos. Brasília: SNSA/MCIDADES.

Streble, H.; Krauter, D. (1987). Atlas de los Microorganismos de Agua Dulce La vida em uma gota de água. Omega.

Torres, P. L.; Foresti, E.; Vazoller R. (1996). "Composición y uso de agua residual doméstica en reactores a escala de laboratório". In: XXV Congreso Interamericano de Ingenieria Sanitaria y Ambiental, Cidade do México, México. Anais do XXV Congreso Interamericano de Ingenieria Sanitaria y. Ambiental. Cidade do México: IAWQ.

Von Sperling, M. (1996). Princípio básicos do tratamento de esgotos. (Vol. 2). Belo Horizonte: Departamento de ENgenharia Sanitaria e ambiental - UFMG.

Von Sperling, M. (1997). Lodos Ativados (Vol. 4). Belo Horizonte: Departamento de Engenharia Sanitária e Ambiental - UFMG. 
Von Sperling, M.; Andreoli, C. V.; Fernandes, F. (2001). Lodo de esgotos: tratamento e disposição final (Vol. 6). Belo Horizonte: Departamento de Engenharia Sanitária e Ambiental, UFMG; Companhia de Saneamento do Paraná. 484 p.

Von Sperling, M. (2005). Introdução à qualidade das águas e ao tratamento de esgotos. Princípios do Tratamento Biológico de Águas Residuárias. Belo Horizonte: Departamento de Engenharia Sanitária e Ambiental - UFMG, Vol. 1, 452p.

Referências Bibliográficas com Apud

Ryhiner, G., Birou, B. And Gros, H. (1992). The use of submerged structure packings in biofilm reactors for wastewater treatment. Water Science and Technology, 26 (3-4): 723-31.

Young, J.C.; Mccarty, P.L. The anaerobic filter for waste treatment. Journal Water Pollution Control Federation, v. 41, n.5 (P2), R 160-R 173, 1969. 